\title{
Quarterly Report on the Ferrocyanide Safety Program for the Period Ending June 30, 1995
}

\author{
J. E. Meacham \\ R. J. Cash \\ G. T. Dukelow
}

Date Published

July 1995
DISCLAIMER

This report was prepared as an account of work sponsored by an agency of the United States Government. Neither the United States Government nor any agency thereof, nor any of their employees, makes any warranty, express or implied, or assumes any legal liability or responsibility for the accuracy, completeness, or usefulness of any information, apparatus, product, or process disclosed, or represents that its use would not infringe privately owned rights. Reference herein to any specific commercial product, process, or service by trade name, trademark, manufacturer, or otherwise does not necessarily constitute or imply its endorsement, recommendation, or favoring by the United States Government or any agency thereof. The views and opinions of authors expressed herein do not necessarily state or reflect those of the United States Government or any agency thereof.

Prepared for the U.S. Department of Energy

Office of Environmental Restoration and

Waste Management

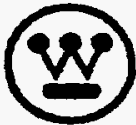

Management and Operations Contractor for the

U.S. Department of Energy under Contract DE-AC06-87RL10930

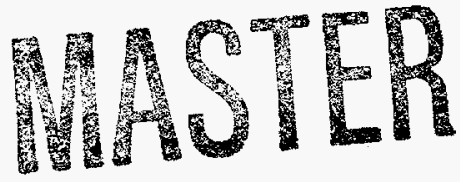

Approved for Public Release 


\section{RELEASE AUTHORIZATION}

Document Number: WHC-EP-0474-17

Document Title: Quarterly Report on the Ferrocyanide Safety Program for the Period Ending June 30, 1995

Release Date: $\quad 8 / 1 / 95$

This document was reviewed following the procedures described in WHC-CM-3-4 and is:

APPROVED FOR PUBLIC RELEASE

WHC Information Release Administration Specialist:

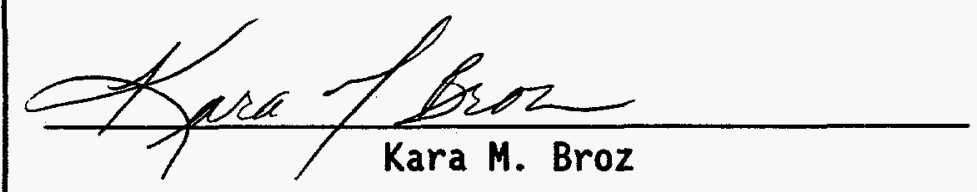




\section{DISCLAIMER}

Portions of this document may be illegible in electronic image products. Images are produced from the best available original document. 


\title{
QUARTERLY REPORT ON THE FERROCYANIDE SAFETY PROGRAM FOR THE PERIOD ENDING June 30, 1995
}

\author{
R. J. Cash \\ J. E. Meacham \\ G. T. Dukelow
}

\begin{abstract}
This is the seventeenth quarterly report on the progress of activities addressing the Ferrocyanide Safety Issue associated with Hanford Site high-level radioactive waste tanks. Progress in the Ferrocyanide Safety Program is reviewed, including work addressing the six parts of Defense Nuclear Facilities Safety Board Recommendation 90-7 (FR 1990). All work activities are described in the revised program plan (DOE 1994b), and this report follows the same format presented there. A summary of the key events occurring this quarter is presented in Section 1.2. More detailed discussions of progress are located in Sections 2.0 through 4.0.
\end{abstract}


This page intentionally left blank. 


\section{CONTENTS}

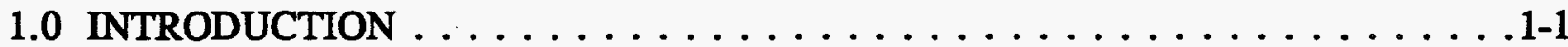

1.1 PURPOSE . . . . . . . . . . . . . . . . . .1-1

1.2 QUARTERLY HIGHLIGHTS $\ldots \ldots \ldots \ldots \ldots \ldots \ldots \ldots \ldots \ldots \ldots \ldots$

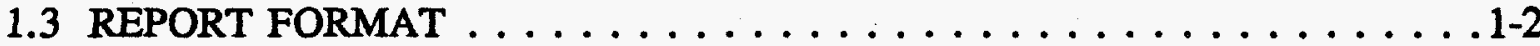

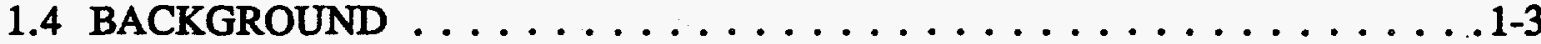

2.0 FERROCYANIDE SAFETY DOCUMENTATION $\ldots \ldots \ldots \ldots \ldots \ldots$

3.0 ACTIONS TO COMPLETE DNFSB RECOMMENDATION 90-7 . . . . . . 3-1

3.1 ENHANCED TEMPERATURE MEASUREMENT $\ldots \ldots \ldots \ldots \ldots .1$

3.1.1 Instrument Trees . . . . . . . . . . . . . . . . .3-1

3.1.2 Upgrades to Existing Temperature Monitoring Instrumentation . . . . 3-2

3.1.3 Hot Spot Thermal Modeling $\ldots \ldots \ldots \ldots \ldots \ldots \ldots \ldots . . \ldots .3$

3.1 .4 Infrared Scanning System . . . . . . . . . . . . . . 3-4

3.1.5 Cooling System Requirements . . . . . . . . . . . . . 3-4

3.2 CONTINUOUS TEMPERATURE MONITORING $\ldots \ldots \ldots \ldots \ldots \ldots$. $\ldots \ldots$

3.3 COVER GAS MODELING $\ldots \ldots \ldots \ldots \ldots \ldots \ldots \ldots \ldots \ldots$

3.3.1 Interim Flammable Gas Monitoring . . . . . . . . . . . . 3-6

3.3.2 Continuous Gas Monitoring $\ldots \ldots \ldots \ldots \ldots \ldots \ldots . \ldots \ldots$

3.4 FERROCYANIDE WASTE CHARACTERIZATION . . . . . . . . . . 3-9

3.4.1 Ferrocyanide Tank Waste Sampling and Analyses . . . . . . . . . . 3-9

3.4.2 Estimation of Moisture Content . . . . . . . . . . . . . 3-21

3.4.3 Moisture Retention Properties of Ferrocyanide Sludge and Saltcake Simulants . . . . . . . . . . . . . . . 3-27

3.5 CHEMICAL REACTION STUDIES . . . . . . . . . . . . . . . . 3-29

3.5.1 Chemical Reaction Studies at Pacific Northwest Laboratory . . . . . 3-30

3.5.2 Preparation and Characterization of Ferrocyanide Simulants . . . . . 3-39

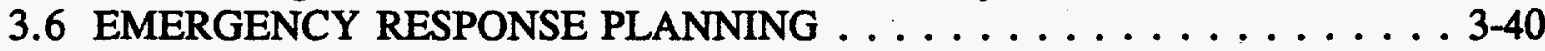

4.0 IMPLEMENTATION OF THE WYDEN AMENDMENT $\ldots \ldots \ldots \ldots \ldots \ldots$. . . .

4.1 THE WATCH LIST $\ldots \ldots \ldots \ldots \ldots \ldots \ldots \ldots \ldots \ldots .4 .1$

4.2 TEMPERATURE MONITORING $\ldots \ldots \ldots \ldots \ldots \ldots \ldots \ldots$ 4-3

4.3 PRESSURE MONITORING $\ldots \ldots \ldots \ldots \ldots \ldots \ldots \ldots \ldots .4$

5.0 PROGRAM SCHEDULES AND MILESTONES $\ldots \ldots \ldots \ldots \ldots \ldots \ldots$. . . . . .

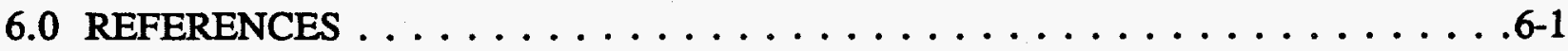

APPENDIX A

FERROCYANIDE TANK INFORMATION SUMMARY $\ldots \ldots \ldots \ldots \ldots$ A-1 


\section{LIST OF FIGURES}

3-1 Spectra of Tank Waste with Low Moisture Content (Tanks 241-B-102, 241-BY-108, 241-BX-105, 241-C-103) . . . . . . . . . . . . 3-16

3-2 Spectra of Tank Waste with High Moisture Content (Tanks 241-AW-101, 241-BY-106, 241-C-102, 241-C-107, 241-C-108, 241-SY-103) . . . . . . . 3-17

3-3 Comparison of Spectra for Wet Tank Waste and Freeze-Dried Tank Waste . . . 3-18

3-4 Neutron Probe Scans of Tank 241-BY-104 Waste . . . . . . . . . . . . 3-23

3-5 Moisture Profile in Tank 241-BY-104 Waste . . . . . . . . . . . . . . . . . . . 3-24

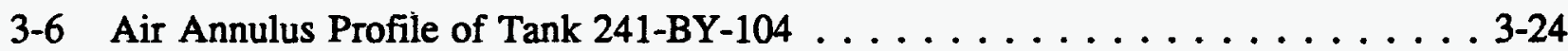

3-7 Least Squares Fit of $\mathrm{NH}_{3}$ Production as a Function of Time for Temperatures of $50,70,80,90$, and $100{ }^{\circ} \mathrm{C} \ldots \ldots \ldots \ldots .32$

3-8 Eyring Plot for $\mathrm{NH}_{3}$ Production as a Function of Temperature $\ldots \ldots \ldots \ldots$ 3-32

3-9 Least Squares Fit of $\mathrm{NH}_{3}$ Production as a Function of Time for Various Gamma Dose Rates . . . . . . . . . . . . . . . . . . . . 3-33

3-10 Ammonia Production as a Function of Gamma Dose Rate at $90{ }^{\circ} \mathrm{C} \ldots \ldots$. . . 3-33

3-11 Ammonia Production as a Function of Time at $\mathrm{pH} 10,60^{\circ} \mathrm{C}$ and a Gamma Dose

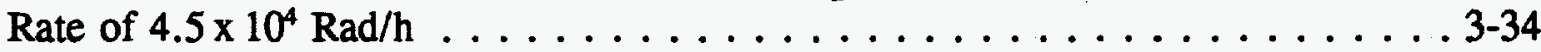

3-12 FTIR Spectrum of Samples from Tank 241-C-112, Core 36, Composite 2C . . . 3-35

5-1 Ferrocyanide Waste Tank Safety Schedule $\ldots \ldots \ldots \ldots \ldots \ldots \ldots \ldots$. . . . . 


\section{LIST OF TABLES}

3-1 Analyses of Sludge from $241-B Y-106 \ldots \ldots \ldots \ldots \ldots \ldots \ldots \ldots \ldots$ 3-10

3-2 Tank 241-C-111 Sampling Results $\ldots \ldots \ldots \ldots \ldots \ldots \ldots$. . . . . . . . . . . . .

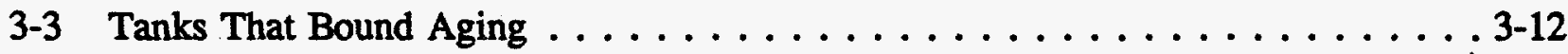

3-4 The Effect of Ion Exchange on Cyanide Analyses for Samples from Tanks 241-C-109 and 241-C-112 . . . . . . . . . . . . . . . . 3-35

3-5 Cesium Distribution Coefficients for U Plant 2 and In Farm 2 Waste Simulants . 3-36

3-6 Comparison of In Farm Simulant and Samples from Tank 241-C-109 . . . . . . 3-37

3-7 Comparison of In Farm Simulant and Samples from Tank 241-C-112 . . . . . . 3-37

A-1 Summary of Contents and Status of Ferrocyanide Tanks $\ldots \ldots \ldots \ldots \ldots$ A-3

A-2 Ferrocyanide Tank Vapor Sampling Summary $\ldots \ldots \ldots \ldots \ldots \ldots$ A-5 


\section{LIST OF TERMS}

\begin{tabular}{|c|c|}
\hline ASA & Accelerated Safety Assessment \\
\hline CASS & Computer Automated Surveillance System \\
\hline DNFSB & Defense Nuclear Facilities Safety Board \\
\hline DOE & U.S. Department of Energy \\
\hline DQO & Data Quality Objectives \\
\hline DSC & Differential Scanning Calorimetry \\
\hline EA & Environmental Assessment \\
\hline EDS & Energy Dispersive X-Ray Spectroscopy \\
\hline EMI & Electromagnetic Induction \\
\hline FAI & Fauske and Associates, Inc. \\
\hline FTIR & Fourier Transform Infrared \\
\hline FY & Fiscal Year \\
\hline g-mole & Gram-Mole \\
\hline GAO & U.S. General Accounting Office \\
\hline IR & Infrared \\
\hline ISB & Interim Safety Basis \\
\hline $1 / 0$ & Input/Output \\
\hline $\mathbf{k W}$ & Kilowatt \\
\hline LANL & Los Alamos National Laboratory \\
\hline LOW & Liquid Observation Well \\
\hline $\mathrm{mmol} / \mathrm{g}$ & Millimoles Per Gram \\
\hline NASA & National Aeronautics and Space Administration \\
\hline NIOSH & National Institute of Occupational Health and Safety \\
\hline NIR & Near Infrared \\
\hline PNL & Pacific Northwest Laboratory \\
\hline ppmv & Parts Per Million By Volume \\
\hline $\mathrm{Rad} / \mathrm{h}$ & Rad Per Hour \\
\hline SA & Safety Assessment \\
\hline SEM & Scanning Electron Microscope/Microscopy \\
\hline SRL & Savannah River Laboratory \\
\hline SST & Single-Shell Tank \\
\hline TC & Thermocouple \\
\hline TMACS & Tank Monitor and Control System \\
\hline TNMOC & Total Non-Methane Organic Carbon \\
\hline TOC & Total Organic Carbon \\
\hline USQ & Unreviewed Safety Question \\
\hline vol\% & Volume Percent \\
\hline VSS & Vapor Sampling System \\
\hline WSU & Washington State University \\
\hline$w t \%$ & Weight Percent \\
\hline
\end{tabular}




\subsection{INTRODUCTION}

\subsection{PURPOSE}

This quarterly report provides a status of activities underway on the Ferrocyanide Safety Issue at the Hanford Site, including actions in response to Defense Nuclear Facilities Safety Board (DNFSB) Recommendation 90-7 (FR 1990). In March 1991, a DNFSB implementation plan (Cash 1991) responding to the six parts of Recommendation 90-7 was prepared and sent to the DNFSB. A Ferrocyanide Safety Program Plan addressing the total Ferrocyanide Safety Program, including the six parts of DNFSB Recommendation 90-7, was released in October 1994 (DOE 1994b). Activities in the program plan are underway or have been completed, and the status of each is described in Sections 2.0 and 3.0 of this report.

\subsection{QUARTERLY HIGHLIGHTS}

- Instrument trees in tanks 241-T-107 and -TY-104 were connected to the Tank Monitor and Control System (TMACS) on April 12, 1995. This action completed Tri-Party Agreement (Ecology et al. 1994) milestone M-40-02B.

- Vapor samples were taken from the remaining three ferrocyanide tanks this quarter, 241-TY-101, -TY-103, and -TY-104. All 18 Ferrocyanide Watch List tanks have now been sampled and analyzed (see Table A-2 in Appendix), closing out DNFSB Recommendation 90-7.3 and satisfying Tri-Party Agreement milestone M-40-03. Dome space sampling of Ferrocyanide Watch List tanks will continue on a periodic basis as part of the Tank Vapor Monitoring Program.

- Analyses on the small amount of sludge $(\sim 5 \mathrm{~cm})$ recovered from tank 241-BY-106 were completed this quarter (Bell 1995). Three differential scanning calorimetry (DSC) analyses on the sludge material measured $670,1,400$, and $670 \mathrm{~J} / \mathrm{g}$ on a dry basis. However, the nickel, total cyanide, and total organic carbon (TOC) analyses showed that this fuel value is organic and that the ferrocyanide had aged as anticipated.

- Analyses were completed on the auger samples from tank 241-C-111 (Rice 1995), and DSC analyses revealed no exothermic energy for all of the samples. The material recovered from riser three did not appear to be ferrocyanide sludge. No water was measured in these samples, but large endothermic activity and substantial mass loss was noted at about $200^{\circ} \mathrm{C}$. This waste is believed to be aluminum decladding waste, similar to that found in tank 241-C-109. 
- The ferrocyanide data quality objectives (DQO) document was revised this quarter (Meacham et al. 1995a). The most substantive change in the revision is the optimization of tank sampling to bound ferrocyanide aging. Tanks with high ferrocyanide concentrations and sludge depths, and low temperature and radiation dose histories, have been selected for core sampling to bound aging.

- Liquid observation well (LOW) material was analyzed for iron by Mössbauer spectroscopy. Both of the LOW materials were found to contain magnetic iron as shown by the hyperfine splitting of the spectrum. However, the LOW iron shows a significantly different spectrum from the waste simulants, and it should be possible to still detect iron in the waste.

- Neutron probe scans from tank 241-BY-104 were interpreted by the TMAD computer code. The code is predicted about 17 weight percent (wt\%) moisture in the saltcake and about $30 \mathrm{wt} \%$ moisture in the sludge. The moisture prediction in the saltcake region of the tank agrees with analyses of two auger samples (15 and $17 \mathrm{wt} \%$ water) taken from this tank (Neskas and Borsheim 1993).

- A simplified model for the steady evaporation of moisture from a saltcake waste surface was devised based on principles of unsaturated liquid flow in a porous matrix. The model as conceptualized represents a first step in connecting evaporation with interstitial liquid flow controlled by capillarity.

- Ferrocyanide waste simulants were exposed to various temperatures and gamma dose rates to determine the effect of temperature and dose rate on hydrolysis. Results indicate that ammonia production varies almost linearly with gamma dose rate and temperature.

\subsection{REPORT FORMAT}

Progress reports for activities under each of the six parts of DNFSB Recommendation 90-7 are arranged in the same order as the program plan (DOE 1994b). The arrangement also follows the same order provided in Recommendation 90-7. To report on progress, each part of the recommendation is repeated in italics, followed by paragraphs explaining the scope of work on each part or subpart of the recommendation. Subheadings for each task activity report the following:

- Progress During Reporting Period

- Planned Work for Subsequent Months

- Problem Areas and Action Taken

- Milestone Status. 


\subsection{BACKGROUND}

Various high-level radioactive wastes from defense operations have accumulated at the Hanford Site in underground storage tanks since the mid-1940s. During the 1950s, additional tank storage space was required to support the defense mission. To obtain this additional storage volume within a short time period, and to minimize the need for constructing additional storage tanks, Hanford Site scientists developed a process to scavenge ${ }^{137} \mathrm{Cs}$ and ${ }^{90} \mathrm{Sr}$ from tank waste liquids. In implementing this process, approximately 140 metric tons (154 tons) of ferrocyanide were added to waste that was later routed to a number of Hanford Site single-shell tanks (SSTs) (Sloat 1954, 1955).

In the presence of oxidizing material such as sodium nitrate and/or nitrite, ferrocyanide can be made to react exothermically by heating it to high temperatures or by applying an electrical spark of sufficient energy (Cady 1993). However, fuel, oxidizers, and temperature are all important parameters. If fuel, oxidizers, or high temperatures (initiators) are not present in sufficient amounts, then a runaway or propagating reaction cannot occur.

In 1990, little was known about the potential hazards of a ferrocyanide-nitrate/nitrite reaction in Hanford Site SSTs. Because the safety envelope was not adequately defined by existing analyses, an inadequacy existed in the authorization basis ${ }^{1}$. That is, the existing safety analysis report (Smith 1986) and subsequent analyses such as the 1987 Environmental Impact Statement (DOE 1987) did not adequately define the conditions necessary to preclude propagating reactions in the ferrocyanide waste; therefore, an unreviewed safety question (USQ) was declared (Deaton 1990).

Based on the knowledge gained from simulant studies, theoretical analyses, and analyses of actual waste samples, safety criteria were defined for the ferrocyanide waste (Postma et al. 1994a). These criteria were reviewed and accepted by outside reviewers and reviewers within the U.S. Department of Energy (DOE). The USQ was closed on March 1, 1994 by the DOE Assistant Secretary for Environmental Restoration and Waste Management (Sheridan 1994a).

In September 1990, an Ad Hoc Task Force report (Kress et al. 1990) recommended that studies be performed to provide information on: (1) the potential for a ferrocyanidenitrate/nitrite explosion; (2) the conditions necessary in the tanks to initiate an explosion; and (3) the potential consequences of such an occurrence. The U.S. General Accounting Office (GAO) advised the Secretary of Energy to implement these recommendations (Peach 1990).

${ }^{1}$ The DOE authorization basis characterizes the facility design basis and operational requirements for each nuclear facility. The authorization basis is described in documents such as facility safety analysis reports and other safety analyses, hazard classification documents, technical safety requirements, DOE-issued safety evaluation reports, and facility-specific commitments, such as safety assessments for specific tank operations and the Interim Safety Basis (Wagoner 1993). 
A closeout report addressing all three of the GAO recommendations was submitted to DOE in June 1994 (Payne 1994a). The report summarizes the progress made on determining the potential for ferrocyanide reactions in Hanford Site ferrocyanide tanks, and the conditions necessary to sustain an exothermic ferrocyanide reaction.

In March 1989 (Nguyen 1989), using process knowledge, process records, transfer records, and $\log$ books, 22 Hanford Site tanks were identified as potentially containing 1,000 gram-moles ( $\mathrm{g}$-moles) ${ }^{2}$ [211 kg (465 lb)] or more of ferrocyanide [as the $\mathrm{Fe}(\mathrm{CN})_{6}^{4}$ anion]. Two additional ferrocyanide tanks were identified in January 1991 (Borsheim and Cash 1991), increasing the number of ferrocyanide tanks to 24. To avert possible injury to personnel and damage to the facility or environment, strict controls were identified for these and other safety issue tanks in the Operating Specifications for Watch List Tanks (WHC 1990). Tanks identified via this document (see WHC [1994] for the latest revision) have been commonly referred to as Watch List tanks. In October 1990 (Deaton 1990), the Ferrocyanide Safety Issue was declared a USQ (see Section 2.1) because the safety envelope for these tanks was no longer considered to be bounded by the existing safety analysis report (Smith 1986).

In November 1990, the Wyden Amendment (Public Law 101-510, Section 3137, 1990) was enacted. This law required the identification of Hanford Site tanks that may have a serious potential for release of high-level waste (see Section 4.0). In February 1991 (Harmon 1991), the 24 ferrocyanide tanks were among the tanks identified, and were included in the subsequent July 1991 report to Congress (Watkins 1991) that responded to the Wyden Amendment. However, re-examination of the historical records (Borsheim and Simpson 1991 ) indicated that six of the 24 tanks did not contain the requisite $1,000 \mathrm{~g}$-moles of ferrocyanide. Therefore, these six tanks should not have been included on the Watch List nor been identified in the response to the Wyden Amendment. The six tanks were subsequently removed from the Watch List (Anttonen 1993, Sheridan 1994b).

${ }^{2}$ The $1,000 \mathrm{~g}$-moles criterion has since been replaced with a $115 \mathrm{cal} / \mathrm{g}$ fuel concentration criterion. See Section 4.1 for discussion. 


\subsection{FERROCYANIDE SAFETY DOCUMENTATION}

The USQ process depends on an authorization basis that describes those aspects of the facility design basis and operational requirements relied on by DOE to authorize operation. The authorization basis is described in documents such as facility safety analysis reports and other safety analyses, hazard classification documents, technical safety requirements, DOE-issued safety evaluation reports, and facility-specific commitments, such as safety assessments (SAs), the interim safety basis (ISB), and the new Accelerated Safety Assessment (ASA) scheduled for approval later this year. The potential hazards of a ferrocyanide-nitrate/nitrite reaction were discovered to represent an inadequacy in the authorization basis (Smith 1986). The Ferrocyanide USQ was closed on March 1, 1994 by the DOE Assistant Secretary for Environmental Restoration and Waste Management (Sheridan 1994a). Progress on the remaining safety documentation for resolving the Ferrocyanide Safety Issue is reviewed in this section.

Safety and Environmental Assessments. SAs are documents prepared to provide the technical basis to assess the safety of a proposed activity and to provide proper controls to maintain safety. The SA and the accompanying environmental assessment (EA) for that operation provide the basis for DOE authorization of the proposed activities. SAs have been approved for dome space sampling of all ferrocyanide tanks, waste surface sampling, push-mode and rotary-mode core sampling, thermocouple (TC)/instrument tree installation in sound and assumed leaker tanks, and removal of pumpable liquid (interim stabilization).

A generic EA covering all proposed operations in the tank farms was approved and a Finding of No Significant Impact issued by DOE (Gerton 1994). Approval of the generic EA provides adequate National Environmental Policy Act coverage for the planned Ferrocyanide Safety Program activities.

The authorization basis for intrusive tank operations was combined into one document, the ISB, which was approved in November 1993 (Wagoner 1993). Safety documentation concerning the ferrocyanide hazard was updated to reflect the approved ferrocyanide safety criteria and closure of the Ferrocyanide USQ. This information is also being incorporated into the ASA that will replace the ISB when approved by DOE.

Hazard Assessment. A report assessing the ferrocyanide waste tank hazards was issued in July 1992 (Grigsby et al. 1992). The report reviewed the understanding of the ferrocyanide hazard at that time, and presented an integrated evaluation and interpretation of historical data and then-available information. Additional data are now available on the potential for exothermic ferrocyanide reactions in Hanford Site SSTs. A final ferrocyanide hazard assessment will be submitted to DOE by July 31, 1996. Technical information from all Ferrocyanide Safety Program tasks will be compiled into this document, and the ISB (or ASA) will be amended accordingly. 
Ferrocyanide Program Plan. A ferrocyanide program plan was submitted to the DNFSB in December 1994 (O'Leary 1994). The program plan outlines activities planned to address DNFSB Recommendation 90-7, to meet the Wyden Amendment requirements (Public Law 101-510, Section 3137, 1990), and to remove the remaining ferrocyanide tanks from the Watch List. All ferrocyanide program activities are scheduled to be completed by the end of fiscal year (FY) 1997. However, an increased understanding of radiolytic and chemical degradation (aging) of ferrocyanide indicates that little ferrocyanide remains, and core sampling of all the tanks may not be required. Core sampling and analyses of only those tanks that bound aging (i.e., tanks with conditions least conducive to aging) could result in resolution of the Ferrocyanide Safety Issue much earlier and at a substantially reduced cost. As more core sample data become available, the need to sample all the ferrocyanide tanks will be reexamined.

- Milestone Status

- January 31, 1996. Westinghouse Hanford Company issues documentation supporting safety issue resolution for the four C Farm tanks, and recommends Ferrocyanide Safety Issue resolution for C Farm tanks.

- July 31, 1996. Westinghouse Hanford Company receives DOE approval for Ferrocyanide Safety Issue resolution for C Farm tanks.

- July 31, 1996. Westinghouse Hanford Company prepares and submits the final ferrocyanide hazard assessment for DOE approval.

- March 31, 1997. Westinghouse Hanford Company issues documentation to support safety issue resolution for the remaining 14 tanks and recommends Ferrocyanide Safety Issue resolution for all remaining tanks.

- September 30, 1997. Westinghouse Hanford Company receives DOE approval for Ferrocyanide Safety Issue resolution. 


\subsection{ACTIONS TO COMPLETE DNFSB RECOMMENDATION 90-7}

-This section follows the format of the program plan (DOE 1994b) and describes all work associated with the Ferrocyanide Safety Program. Where applicable, each task activity is described relative to the DNFSB Recommendation (90-7.1 through 90-7.6). The specific part of the recommendation is given, followed by a summary of activities underway to respond to that part of Recommendation 90-7 (if not already closed out).

\subsection{ENHANCED TEMPERATURE MEASUREMENT}

"Immediate steps should be taken to add instrumentation as necessary to the SSTs containing ferrocyanide that will establish whether hot spots exist or may develop in the future in the stored waste. The instrumentation should include, as a minimum, additional thermocouple trees. Trees should be introduced at several radial locations in all tanks containing substantial amounts of ferrocyanide, to measure the temperature as a function of elevation at these radii. The use of infrared techniques to survey the surface of waste in tanks should continue to be investigated as a priority matter, and on the assumption that this method will be found valuable, monitors based on it should be installed now in the ferrocyanide bearing tanks."

\subsubsection{Instrument Trees}

Work in several areas has developed a broader knowledge base and has warranted several changes in the approach to implementing this recommendation. Originally, it was planned to add several temperature measurement instruments to each tank. This plan has been modified to ensure that at least one instrument tree with replaceable temperature-sensing elements is in each ferrocyanide tank. Additionally, at least two operational temperature-sensing elements should be in the waste to ensure a true temperature measurement, and one or more elements should be in the dome space.

The new data that have warranted this action include the following: (1) many of the TC elements in the existing trees have been retumed to service, and measured temperatures are as expected; (2) thermal modeling to date (McLaren 1994a, 1994b) and an enhanced understanding of waste properties show that formation of hot spots in ferrocyanide tanks is not credible (Dickinson et al. 1993, Epstein et al. 1994); and (3) new calculations of tank heat content based on tank temperatures show lower values than previous estimates (Crowe et al. 1993, McLaren 1994a, 1994b).

When all instrument trees are installed, there will be two instrument trees in all but three ferrocyanide tanks (241-BY-106, -111 and -112). Tanks 241-BY-105 and -106 already contain instrument trees with replaceable temperature-sensing elements. Earlier, tanks 241-BY-111 and -112 had no operable instrument trees, and the waste temperatures 
were measured via a dedicated TC element installed into each tank's LOW. New instrument trees with replaceable temperature-sensing elements were installed in these two tanks in March 1993. The existing instrument trees in the ferrocyanide tanks will be monitored in addition to newly installed trees. The older trees are expected eventually to fail in a manner such that they cannot be repaired, and they will undoubtedly not be replaced.

- Progress During Reporting Period. All equipment and safety documentation supporting insertion of the remaining five trees has been completed. Work packages for the field work to install the remaining instrument trees have been completed for the two TY tanks. Installation of the last five instrument trees remains on schedule.

- Planned Work for Subsequent Months. Five instrument trees will be installed into the remaining assumed-leaker ferrocyanide tanks. The remaining five trees in tanks 241-BY-103, 241-BY-108, 241-C-111, 241-TY-101, and 241-TY-103 are expected to be installed before the end of August 1995. Completion of the milestones listed below requires that the respective instrument trees be connected to TMACS.

- Problem Areas and Action Taken. None.

- Milestone Status.

- April 30, 1995. Westinghouse Hanford Company completes installation of two of seven instrument trees in assumed leaker ferrocyanide tanks (Tri-Party Agreement milestone M-40-02B). The second of these seven trees was installed in March 1995 in tank 241-TY-104 after auger sampling was completed in the shallow-depth tank. Both this tree and the one installed in tank 241-T-107 in November 1994 were connected to TMACS by April 12, 1995.

- September 30, 1995. Westinghouse Hanford Company completes installation of remaining five instrument trees in assumed-leaker ferrocyanide tanks (Tri-Party Agreement Milestone M-40-02). This milestone will be complete when all five instrument trees are connected to TMACS. The milestone also closes out DNFSB Recommendation 90-7.1.

\subsubsection{Upgrades to Existing Temperature Monitoring Instrumentation}

This task determined the operability and accuracy of previously installed TC elements in the original 24 Ferrocyanide Watch List tanks. The original and newly installed instrument trees provide temperature measurements for the ferrocyanide tanks.

Field measurements were taken in 1991 on each TC element in the then-existing trees to determine the resistance and voltage across the junction and across each lead to ground. The exact condition of each TC element was determined by resistance and voltage measurements (Bussell 1992). This work was completed in FY 1991 with a total of 265 TC elements being 
evaluated. Work in FY 1992 focused on repair and recovery of 92 TC elements that were found to be failed or marginal in performance. This task was completed in FY 1992.

- Progress During Reporting Period. No progress was required or planned.

- Planned Work for Subsequent Months. None.

- Problem Areas and Actions Taken. None.

- Milestone Status. This task is complete.

\subsubsection{Hot Spot Thermal Modeling}

Radioactive materials decaying in Hanford Site waste tanks generate heat. An early concern, raised when the ferrocyanide tanks first became a safety issue, was whether an exothermic excursion and local propagation could occur within the ferrocyanide waste if a sufficient concentration of ferrocyanide and a high enough temperature were present. This task examined the available temperature data from the ferrocyanide tanks in order to determine the heat load and temperatures as a function of depth and radial location. Sensitivity and parametric analyses were included to determine the magnitude of a hot spot that would have to exist for the waste to reach propagation temperatures.

Heat load analyses and thermal characteristics were completed for all ferrocyanide tanks in FY 1994 (McLaren 1994a, 1994b). The maximum heat load of any ferrocyanide tank, assuming worst-case conditions for soil moisture and thermal conductivity, was below 4.2 kilowatts (kW). Nominal heat loads calculated by McLaren (1994a, 1994b) compared very favorably with those calculated independently in 1993 (Crowe et al. 1993). A dryout analysis was also completed and released in FY 1994 (Epstein et al. 1994). The report concluded that ferrocyanide sludge could not dry sufficiently to be chemically reactive during interim storage, either globally or locally. Dryout mechanisms evaluated included global evaporation, removal of liquid by leakage or pumping, boiling as a result of hot spots, and enhanced surface evaporation from hot spots. All activities were completed for this task in FY 1994.

- Progress During the Reporting Period. None.

- Planned Work for Subsequent Months. None.

- Problem Areas and Action Taken. None.

- Milestone Status. This task is complete. 


\subsubsection{Infrared Scanning System}

Infrared (IR) scanning systems are commercially available from numerous vendors. These systems are sensitive to changes of $\pm 0.3{ }^{\circ} \mathrm{C}$ or less under ideal conditions and offer promise for mapping surface temperature profiles in the ferrocyanide tanks. Thermal modeling performed on ferrocyanide tank 241-BY-104 (McLaren 1993) suggested that if hot spots with temperatures of concern are possible, surface temperature differences might be great enough to be detected by IR mapping.

A position paper on the credibility of hot spots and the need for further IR scanning was issued in April 1993 (Dickinson et al. 1993). Further analyses have been performed to assess potential dryout of the ferrocyanide waste (Epstein et al. 1994). These reports examined potential mechanisms for forming hot spots. Analyses indicate that hot spots are not credible in ferrocyanide tanks. Based on these analyses, Westinghouse Hanford Company recommended that no further planning be pursued for IR scans for the purpose of detecting hot spots.

- Progress During the Reporting Period. None.

- Planned Work for Subsequent Months. None.

- Problem Areas and Action Taken. None.

- Milestone Status. This task is complete.

\subsubsection{Cooling System Requirements}

The program plan for resolution of the Ferrocyanide Safety Issue (DOE 1994b) provided actions that would be taken to cool the ferrocyanide tanks if determined to be necessary. Several tentative milestones, identified below, were established if a cooling system(s) were required. The concern at the time was that increasing temperatures could lead to loss of moisture within the ferrocyanide waste matrix. Immediate emergency actions that would be taken if increased temperatures were to occur are described in the Action Plan for Response to Abnormal Conditions in Hanford Site Radioactive Waste Tanks Containing Ferrocyanide (Fowler 1994). Types of cooling systems might include, but are not limited to the following: (1) forced ventilation of the tank, using an existing or new exhauster system; (2) air conditioning the air to the tank; (3) adding humid air or mist; and (4) adding water to the tank.

Based on the historical database, results of samples from seven ferrocyanide tanks and results from the PNL aging test activity, there is not a high enough concentration of ferrocyanide in any of the 18 tanks for a propagating reaction to occur. Since dryout of the waste under the present storage conditions (Epstein et al. 1994) is not credible, a special cooling system for the ferrocyanide tanks is not considered necessary. 
- Progress During the Reporting Period. A decision was made this quarter not to perform an engineering study of potential cooling systems for ferrocyanide tanks, since there is no indication of increasing temperatures in any of the 18 tanks. Data now available for the ferrocyanide waste demonstrates that the fuel has degraded to values well below that required for a propagating reaction.

- Planned Work for Subsequent Months. None, assuming no increasing temperature trends in the ferrocyanide tanks are observed.

- Problem Areas and Action Taken. None.

- Milestones Status.

- September 30, 1995. Westinghouse Hanford Company completes an engineering study (if required) to identify the best system for controlling tank temperature. This milestone has been deleted and notification of this change is hereby provided in accordance with Section 3.7 of the program plan (DOE 1994b).

- January 31, 1996. Department of Energy decides whether a cooling system should be available as a contingency action. Westinghouse Hanford Company initiates fabrication/purchase of the cooling system, as required. This milestone has been deleted and notification of this change is hereby provided in accordance with Section 3.7 of the program plan (DOE 1994b).

- September 30, 1997. Westinghouse Hanford Company fabricates and installs cooling systems (if required). This milestone has been deleted and notification of this change is hereby provided in accordance with Section 3.7 of the program plan (DOE 1994b).

\subsection{CONTINUOUS TEMPERATURE MONITORING}

"The temperature sensors referred to above [Recommendation 90-7.1] should have continuous recorded readouts and alarms that would signal at a permanently manned location any abnormally high temperatures and any failed temperature instrumentation."

This task provides continuous monitoring of presently installed (and operable) temperaturesensing elements for the ferrocyanide tanks. New instrument trees will be connected to the system as they are installed into each tank, resulting in continuous temperature monitoring in the ferrocyanide tanks. All data are collected automatically at the continuously manned Computer Automated Surveillance System (CASS) Operator Control Station. The monitoring system is independent of the CASS and is capable of displaying data to an operator on request. Trend data on selected points are available for display in numeric or graphic form. 
The TMACS system, which became operational in September 1991, has the capacity to assign alarms for a change in the value of any temperature point. Alarms, if they occur, trigger an audible annunciator and are logged immediately to hard copy. An alarm summary display provides a list of the most recent alarms in order of occurrence. Each alarm can be identified by point and time of occurrence. Operator acknowledgement of the alarm will silence the audible annunciator. Signal conditioning and multiplexing are performed locally at each tank, eliminating the need to transmit low-level signals to the tank farm boundary and reducing cable runs. Electronic noise, extension wire corrosion, and thermal gradients are also reduced.

- Progress During Reporting Period. Two instrument trees, one in tank 241-T-107 and one in tank 241-TY-104, were connected to TMACS in April. This completes Tri-Party Agreement Milestone M-40-02B (see Section 3.1.1).

- Planned Work For Subsequent Months. Connection of new instrument trees to TMACS will be made as soon as practical after the trees are installed. Next quarter, trees in tanks 241-BY-107 and 241-TX-118 will be connected to TMACS for continuous monitoring. Each of these tanks contains an older tree that is already being monitored continuously by TMACS.

- Problem Areas and Action Taken. None.

- Milestone Status.

- September 30, 1995. Westinghouse Hanford Company completes TMACS connections for all installed instrument trees in ferrocyanide tanks. This milestone completes Tri-Party Agreement Milestone M-40-02 and also closes out DNFSB Recommendation 90-7.2.

\subsection{COVER GAS MODELING}

"Instrumentation should also be installed to monitor the composition of cover gas in the tanks, to establish if flammable gas is present."

\subsubsection{Interim Flammable Gas Monitoring}

The effort to conduct flammable and toxic gas monitoring and analyses in the ferrocyanide tanks is continuing. Most of this effort was transferred to the Tank Vapor Monitoring Program, which is coordinating interim gas monitoring of the ferrocyanide tanks as well as those tanks involved with the tank vapor program. Tank dome spaces are measured for flammability using a commercial combustible gas monitor (calibrated with pentane gas), and 
are monitored for potential toxic gases using an organic vapor monitor and Dräger ${ }^{3}$ tubes. Dome space characterization of all the Hanford Site high-level waste tanks is continuing using sorbent tubes placed on the end of tubes lowered into the dome space and SUMMA canisters that collect gas samples topside. The initial dome space sampling was done in several tank locations (i.e., from two widely separated risers) and at three elevations in the dome space. Reviews of sampling data and modeling (Wood 1992, Claybrook and Wood 1994, Postma et al. 1994b) indicate that the dome space is well mixed and that sampling from one riser at one elevation is adequate.

- Progress During Reporting Period. Vapor samples have now been taken from all 18 ferrocyanide tanks using the mobile vapor sampling system (VSS - Type 3 in Table A-2) . The remaining tanks, 241-TY-101, -TY-103, and -TY-104, were sampled in April 1995. Tank Characterization Reports on all 18 ferrocyanide tanks (as well as other tanks) were released in May 1995. Analyses reports for the three TY-Farm tanks show ammonia $\left(\mathrm{NH}_{3}\right)$ values from 16 to 61 parts per million volume (ppmv), nitrous oxide $\left(\mathrm{N}_{2} \mathrm{O}\right)$ values from 98 to $158 \mathrm{ppmv}$, and total non-methane organic compounds (TNMOC) ranging from 1.0 to $60 \mathrm{mg} / \mathrm{m}^{3}$. The combined values for nitric oxide (NO) and nitrogen dioxide $\left(\mathrm{NO}_{2}\right)$ were less than or equal to $0.2 \mathrm{ppmv}$, and carbon dioxide $\mathrm{CO}_{2}$ ranged from less than 23 to $121 \mathrm{ppmv}$. The reported results have been incorporated into Table A-2 of Appendix A. This table lists vapor sampling results available as of June 30, 1995.

Ammonia concentrations for the 18 ferrocyanide tanks ranged from a low of $0.1 \mathrm{ppmv}$ (241-C-108) to a high of $1040 \mathrm{ppmv}$ (241-BY-108). The National Institute of Occupational Safety and Health (NIOSH) 8-hour recommended exposure limit is 25 ppmv (NIOSH 1995). $\mathrm{NO}_{2}$ concentrations ranged from $16.5 \mathrm{ppmv}$ (tank 241-BY-103) to 641 ppmv (241-BY-108) using the VSS method. Hydrogen concentrations for the ferrocyanide tanks have all been lower than about $400 \mathrm{ppmv}$ (241-BY-108) using the VSS method. Water content readings (percent relative humidity) ranged from $27 \%(241-\mathrm{BY}-111)$ to $88 \%$ (241-TY-104). The sludge-only tanks always showed higher relative humidity numbers (76 to $88 \%$ ), while the sludgeplus-saltcake tanks exhibited lower numbers ( 27 to $82 \%$ ). It is interesting to note that tank 241-BY-108 exhibited some of the highest values found in any of the waste tanks sampled to date for $\mathrm{NH}_{3}, \mathrm{~N}_{2} \mathrm{O}$, and TNMOC determinations. This tank is a suspect organic tank and is one of the highest-priority tanks for rotary-mode core sampling in FY 1995.

${ }^{3}$ Trademark of Drägerwerk Aktiengesellschaft, Inc., Lubeck, Germany; also National Draeger, Inc., Pittsburgh, Pennsylvania.

${ }^{4}$ Trademark of Molectrics, Inc., Cleveland, Ohio. 
- Planned Work For Subsequent Months. Dome space sampling of the ferrocyanide tanks will continue on a periodic basis as part of the Tank Vapor Monitoring Program. Sampling of the risers and tank dome space using the combustible gas monitor, the organic vapor monitor, and Dräger "tubes is required each time a riser is opened.

- Problem Areas and Actions Taken. None.

- Milestone Status

- September 30, 1995. Westinghouse Hanford Company completes dome space sampling of remaining ferrocyanide tanks. All ferrocyanide tank dome spaces have been sampled and analyzed, completing this milestone and closing out DNFSB Recommendation 90-7.3. Tri-Party Agreement Milestone M-40-03 (complete dome space characterization for all Ferrocyanide Watch List tanks by November 30 , 1995) was also completed. A letter documenting completion of this Tri-Party Agreement milestone will be sent to the Washington Department of Ecology and the U.S. Environmental Protection Agency next quarter.

\subsubsection{Continuous Gas Monitoring}

The possibility that localized concentrations or stratification of gases exist in the tanks has been evaluated. A modeling study to determine airflow patterns in the dome space of tank 241-C-109 was conducted to evaluate the amount of mixing and the local gas concentrations that could occur. The study revealed that the gases in the tank are well mixed and follow Graham's law for gaseous diffusion; therefore, an analysis of a second tank was considered unnecessary (Wood 1992). Studies completed since that time (Claybrook and Wood 1994, Postma et al. 1994b) also confirm that conclusion.

The need for continuous gas monitoring was addressed in a report that also assessed the potential for cyclic venting and the possibility of accumulating flammable gases (Fowler and Graves 1994). The report concluded that continuous flammable gas monitoring in ferrocyanide tanks is not warranted based on: (1) the low concentration of flammable gases found to date; (2) anticipated low ferrocyanide concentrations because of waste aging; (3) analytical results from tanks 241-C-109 and -112 showing that the fuel concentration in the tanks is much lower than postulated by flowsheet values and operating records; and (4) calculations of hydrogen accumulation using realistic generation values and passive ventilation assumptions. Vapor sampling of all 18 ferrocyanide tanks has corroborated that flammable gas concentrations in the ferrocyanide tanks are too low to be of concern. No further activities are planned in this task.

- Progress During Reporting Period. None. 
- Planned Work For Subsequent Months. This task is complete. DOE has concurred that no continuous gas monitoring is required (O'Leary 1994).

- Problem Areas and Actions Taken. None.

- Milestone Status. None

\subsection{FERROCYANIDE WASTE CHARACTERIZATION}

"The program of sampling the contents of these tanks should be greatly accelerated. The proposed schedule whereby analysis of two core samples from each single-shell tank is to be completed by September 1998 is seriously inadequate in light of the uncertainties as to safety of these tanks. Furthermore, additional samples are required at several radii and at a range of elevations for the tanks containing substantial amounts of ferrocyanide."

Characterization of the waste in the ferrocyanide tanks is necessary to: (1) guide further chemical reaction studies with the ferrocyanide waste simulants; (2) determine actual waste chemical and physical properties; (3) determine how the ferrocyanide waste can be safely stored in situ, and the tanks classified by safety category accordingly, until retrieval and disposal actions are completed; and (4) apply the study results to the final remediation of the waste. This information is necessary to resolve the Ferrocyanide Safety Issue.

The important reactive materials present in the ferrocyanide tanks are fuel (ferrocyanides, sulfides, and reduced carbon species such as organic complexants), oxidants (nitrates and nitrites), and inerts or diluents (including phosphates, aluminates, sulfates, carbonates, oxides, and hydroxides). The location of fission products such as ${ }^{137} \mathrm{Cs}$ and ${ }^{90} \mathrm{Sr}$ is important because these products are heat sources and potential source terms in postulated radiological releases from a hypothetical ferrocyanide reaction. The water content of the waste is very important because water's high heat capacity and heat of vaporization make it an effective inerting material. Water can prevent a sustained combustion or a propagating reaction; wet ferrocyanide material would require drying before it could react or propagate.

\subsubsection{Ferrocyanide Tank Waste Sampling and Analyses}

Tank Sampling. Rotary-mode and push-mode sampling capabilities and auger surface sampling are used to obtain waste samples from the Watch List tanks. Tanks without saltcake and with relatively soft waste solids can be sampled by the push-mode method. If a hard saltcake layer is present, rotary-mode sampling can be used. Auger sampling may also be used if the depth of waste is nominally less than $60 \mathrm{~cm}$.

Each core consists of several 48-cm segments (or portions thereof) depending on the depth of the waste in the tank. The sludge layer in these cores will be divided into four $12-\mathrm{cm}$ subsegments for each $48-\mathrm{cm}$ segment. If the tank contains a saltcake layer, the saltcake 
segments will be divided into only two subsegments. Process flowsheet knowledge, tank historical data, and results obtained from tests with ferrocyanide sludge simulants are used to supplement the analytical results from core sampling.

The priority for sampling ferrocyanide tanks has been changed to reflect the need to determine the reactive properties of the contents. In response to DNFSB

Recommendation 93-5 (DOE 1994a) to expedite sampling and analyses required to address safety issues in the Hanford Site Watch List tanks, the analysis plans for future ferrocyanide tank core samples (and the plans for other Watch List tanks) have been revised. The Watch List tanks have been given priority for core sampling, and the number of required analytes was reduced. Analyte selection was refocused primarily on safety-related properties.

- Progress During Reporting Period. Analytical results for the small amount of sludge $(\sim 5 \mathrm{~cm})$ recovered from tank 241-BY-106 were published this quarter (Bell 1995) and are summarized in Table 3-1. Three DSC analyses on the sludge material measured $670,1,400$, and $670 \mathrm{~J} / \mathrm{g}$ on a dry basis. However, the total cyanide and TOC analyses show that this fuel value is organic and not ferrocyanide.

Table 3-1. Analyses of Sludge from 241-BY-106.

\begin{tabular}{|c|c|c|c|c|}
\hline $\begin{array}{c}\text { Energetics } \\
(\mathrm{J} / \mathrm{g})\end{array}$ & $\begin{array}{c}\text { Water } \\
(\mathrm{wt} \%)\end{array}$ & $\begin{array}{c}\text { Nickel } \\
(\mu \mathrm{g} / \mathrm{g})\end{array}$ & $\begin{array}{c}\text { Total Cyanide } \\
(\mu \mathrm{g} / \mathrm{g})\end{array}$ & $\begin{array}{c}\text { TOC } \\
(\mathrm{wt} \%)\end{array}$ \\
\hline $\begin{array}{c}670 \\
1400 \\
670\end{array}$ & 37 & 30,000 & 94 & 2.1 \\
\hline
\end{tabular}

Analyses were are also completed on the auger samples from tank 241-C-111 (Rice 1995); these results are summarized in Table 3-2. DSC analyses revealed no exothermic energy for any of the samples. The material recovered from riser three was grayish white and did not appear to be ferrocyanide sludge. No water was measured in these samples, but large endothermic activity and substantial mass loss was noted at about $200^{\circ} \mathrm{C}$. The water and DSC results are reminiscent of the aluminum decladding waste found in tank 241-C-109 (Simpson et al. 1993a), and the waste recovered from riser three is believed to be aluminum decladding waste. 
Table 3-2. Tank 241-C-111 Sampling Results.

\begin{tabular}{|c|c|c|c|c|}
\hline Riser & Segment* & $\begin{array}{c}\text { Recovery } \\
(\text { Vol\%) }\end{array}$ & $\begin{array}{c}\text { Water } \\
(\text { wt\%) }\end{array}$ & $\begin{array}{c}\text { Energetics } \\
(\mathrm{J} / \mathrm{g})\end{array}$ \\
\hline 3 & A & 20 & 0 & 0 \\
& B & NR $^{* *}$ & - & - \\
\hline & A & $99+$ & 28 & 0 \\
6 & B & $99+$ & 42 & 0 \\
& C & $99+$ & 44 & 0 \\
\hline
\end{tabular}

* The segments are in sequence with " $\mathrm{A}$ " being the top and " $\mathrm{C}$ " being the bottom quarter segment ** NR = No Recovery for this quarter segment

The ferrocyanide DQO document was revised this quarter (Meacham et al. 1995a). The most substantive change in the revision is the optimization of tank sampling to bound ferrocyanide aging. Three parameters strongly affect the rate of aging, temperature, waste $\mathrm{pH}$, and radiation dose. The current fuel concentration is a function of the starting concentration and the amount of aging that has occurred. Historical data show that all the ferrocyanide tanks have been exposed to enough caustic (i.e., high pH) to promote aging (Wodrich et al. 1992). However, there is some question whether the caustic solutions would penetrate more than a meter into the ferrocyanide sludge (McGrail 1994), and ferrocyanide at greater depths may not have been exposed to high $\mathrm{pH}$ solutions. Therefore, sludge depth has been factored into the selection of tanks that bound aging.

Tanks with high ferrocyanide concentrations and sludge depths, and low temperature and radiation dose histories, have been selected for core sampling to bound aging. If the ferrocyanide has aged in these tanks, then as much or more aging should have occurred in the remaining ferrocyanide tanks. Table 3-3 reviews the tanks selected for sampling to bound aging and the reasons for selection. 
Table 3-3. Tanks That Bound Aging.

\begin{tabular}{|c|l|}
\hline Tank & \multicolumn{1}{|c|}{ Primary Reasons for Selection } \\
\hline BY-103 & $\begin{array}{l}\text { High sludge depth (the ferrocyanide inventory from BY-105 was transferred to } \\
\text { this tank). }\end{array}$ \\
\hline BY-104 & High sludge depth and low integrated dose. \\
\hline BY-108 & High sludge depth and low integrated dose. \\
\hline BY-110 & High sludge depth. \\
\hline C-108 & High concentration flowsheet. \\
\hline C-109 & High concentration flowsheet. \\
\hline C-111 & High concentration flowsheet. \\
\hline C-112 & High concentration flowsheet. \\
\hline TY-103 & Low temperature. \\
\hline TY-104 & Low temperature. \\
\hline
\end{tabular}

- Planned Work For Subsequent Months. The ferrocyanide tanks scheduled for core sampling (in sequence) are 241-BY-110, -BY-108, -BY-103, -BY-104, and -TY-103. Tank 241-BY-110 was substituted for tank 241-BY-106 in priority. Tank 241-BY-106 is now scheduled for sampling early in 1996.

- Problem Areas and Actions Taken. The June 30, 1995 milestone to obtain samples from four ferrocyanide tanks has slipped at least one month because of delays in rotary-mode core sampling. Sampling is expected to begin in July on tank 241-BY-110. This tank will be sampled instead of tank 241-BY-106.

- Milestone Status.

- October 31, 1994. Westinghouse Hanford Company secures rotary-core samples from ferrocyanide tank 241-BY-106. Thirteen core segments were attempted in this tank from one of two risers to be sampled. A second attempt was also made in the same riser (10B). Tank 241-BY-110 was substituted for tank 241-BY-106 in priority. Sampling from a second riser in tank 241-BY-106 will not be started until better segment recoveries are demonstrated. Tank 241-BY-106 is currently scheduled for rotary-mode sampling in January - February 1995. 
- June 30, 1995. Westinghouse Hanford Company obtains core and/or auger samples from four ferrocyanide tanks. This milestone will slip up to three months because of delays in resuming rotary-mode core sampling. Full-depth samples were obtained earlier from tanks $241-\mathrm{C}-108,-\mathrm{C}-111$, and $-\mathrm{TY}-104$, and $-\mathrm{BY}-110$ is now scheduled to be sampled by the rotary truck during July - September 1995.

- September 30, 1995. Westinghouse Hanford Company completes data interpretation reports, available for public release, for four ferrocyanide tanks. Reports are being prepared for tanks 241-C-108, -C-111, and -TY-104 and are scheduled for completion before the September 30 milestone. This milestone will slip because of delays in starting rotary-mode core sampling of tank 241-BY-110.

- December 31, 1995. Westinghouse Hanford Company obtains core samples from five additional ferrocyanide tanks. The five additional tanks are all scheduled for sampling in 1995. However, completion of this milestone depends on the timeliness of rotary-mode core sampling.

- March 31, 1996. Westinghouse Hanford Company completes data interpretation reports, available for public release, for five ferrocyanide tanks.

- July 31, 1996. Westinghouse Hanford Company obtains core samples from the remaining ferrocyanide tanks.

- October 31, 1996. Westinghouse Hanford Company completes data interpretation reports, available for public release, for the remaining ferrocyanide tanks.

Infrared Spectroscopy Analyses. The collection of near-infrared (NIR) spectra from archived waste tank waste core samples with various chemical matrices using a Fourier Transform Infrared (FTIR) spectrometry-based fiber optics method is continuing. Calibration of the method using nonradioactive simulants that mimic the actual composition of tank waste was started.

Based on preliminary results, the fiber optic probe fabricated by the Westinghouse Savannah River Laboratory (SRL) in Aiken, South Carolina, could provide sufficient throughput to perform multi-component analyses on diffusely-reflected mixed waste. The probe has a single detector fiber surrounded by six infrared source fibers beveled toward the detector fiber (six around one configuration). This cone-face design causes all fiber optic fields to cross at a fixed distance from the probe surface, forming an effective optical diameter of about one millimeter. The most pressing concern in performing quantitative spectral measurements with this probe is the difficulty of obtaining reproducible data because of the inhomogeneous sample surfaces. The small optical diameter of this probe makes it especially sensitive to surface inhomogeneities. 
The data recorded using this probe show subtle spectral variations on sets of four replicate measurements taken from different locations in the same sample for each of the samples examined. These variations include the appearance of weak interference fringes superimposed on the sample spectra. Interference fringes are caused by the interference of light waves that are reflected at different points along the path of the sampling surface. From calibration considerations, these fringes increase noise of the spectral data, thus degrading the performance prediction of moisture and/or other components of the waste using commercial quantitation software.

To improve sensitivity, design efforts have focused on reducing interference fringes and stray incident infrared light. Substantial improvement in sensitivity can be made through optical or experimental suppression of the interference fringes and elimination of stray light. A new diffuse-reflectance probe, consisting of a collimator, a hollow metallic light guide, focusing optics, and a sapphire window, has been purchased with a delivery date expected in mid-July 1995. The probe will be interfaced to a new 80 -fiber bifurcated fused silica bundle (40-fiber bundle for the infrared source and 40-fiber bundle for the detector assembly in a "salt and pepper" configuration) that can be detached from the fiber bundle for cleaning or replacement. The probe is presently undergoing tests at the vendor's laboratory using Hanford Site waste simulants.

Calibration involves the use of regression mathematics to fit the laboratory-measured properties of a training set of samples to their NIR spectra. Current efforts are underway to examine user-calibrated robust analysis models using full NIR spectra such as principal component regression and partial least squares analyses.

- Progress During Reporting Period. Figure 3-1 shows the collected spectra of some of the low moisture-bearing archived waste core samples using the SRL fiber optic probe. Because of the relatively inharmonic molecular motion and high degree of polarity of water, the first combination band $\left(5,200 \mathrm{~cm}^{-1}\right)$ is very strong and broad compared to those of other bands $\left(7,000 \mathrm{~cm}^{-1}\right.$ region) in the spectra. Fortuitously, this combination band falls in the region where most organic compounds absorb weakly.

Partial dissolution (higher moisture content) of the waste results in changes in peak shapes and disappearance of the small bands in the 7,000 $\mathrm{cm}^{-1}$ region (first overtone of the OH- stretching vibration) as depicted in Figure 3-2. It is often difficult to acquire good spectra from wet samples, particularly those of jelly-like consistencies, with an FTIR spectrometer system. The resulting spectra are noisy even when the number of scans is increased to 256 or more. Collecting spectra at higher resolution will not help resolve overlapped spectral features. Differences in local chemical environment contribute to distinctive spectral features (waste from tanks 241-AW-101 and $-\mathrm{C}-107)$. 
Figure 3-3 compares the effects of freeze-drying on two waste samples. Freezedrying was conducted for six hours at minus $50^{\circ} \mathrm{C}$ using liquid nitrogen $\left(\mathrm{N}_{2}\right)$ as the coolant. As seen in the figure, freeze-drying produced a dramatic change in the NIR spectrum of the 241-C-107 sample. In contrast, freeze-drying has very little effect on the 241-BY-106 sample. The spectra of the freeze-dried and wet 241-BY-106 samples are "virtual" traces. The very small peaks in the $7,000 \mathrm{~cm}^{-1}$ region appear to be noise or interference fringes rather than spectral peaks. The general shape of the 241-BY-106 spectrum suggests the presence of more hydrate-producing salts but less liquid water than the 241-C-107 sample.

- Planned Work For Subsequent Months. More ferrocyanide- and organic-bearing waste will be screened for chemical composition. The modular transfer optic system will be installed to begin collecting mid-infrared spectra of archived tank waste. The ultraviolet/visible accessory of the FTIR system will be installed to enable collection of data using fiber optics and photoacoustic spectroscopy. The far-infrared accessory will also be installed to collect data in the far-infrared region of the light spectrum.

- Problem Areas and Actions Taken. None.

- Milestone Status.

- September 30, 1995. Westinghouse Hanford Company issues a final report on FTIR technology development for determination of moisture and for ferrocyanide and organic species in tank waste samples.

Mössbauer Spectroscopy. A small task on Mössbauer spectroscopy is investigating the physical and chemical nature of iron within ferrocyanide tank waste. The National Aeronautics and Space Administration (NASA) has developed a miniaturized Mössbauer spectrometer that is small enough to perform elevation scans in the LOWs. Iron is a major constituent of ferrocyanide waste and information about its location and composition in the tanks supports safe interim storage and eventual retrieval of the waste.

Mössbauer spectroscopy can provide the valence state of iron as well as specific coordination chemistry for the iron atom. That is, Mössbauer spectroscopy can see differences in anions surrounding the iron cation in a stable crystalline structure and distinguish between different iron-based minerals. A recent development in this type of spectroscopy is the use of reflectance rather than transmission spectroscopy, thus allowing information to be gained in situ. Mössbauer spectroscopy can distinguish between ferrocyanide and ferricyanide complexes and almost any iron compound that might exist within tank waste. By knowing the iron concentration and species as a function of elevation in a given tank, it should be possible to determine how much aging has occurred within the waste. 
Figure 3-1. Spectra of Tank Waste with Low Moisture Content (Tanks 241-B-102, 241-BY-108, 241-BX-105, 241-C-103).
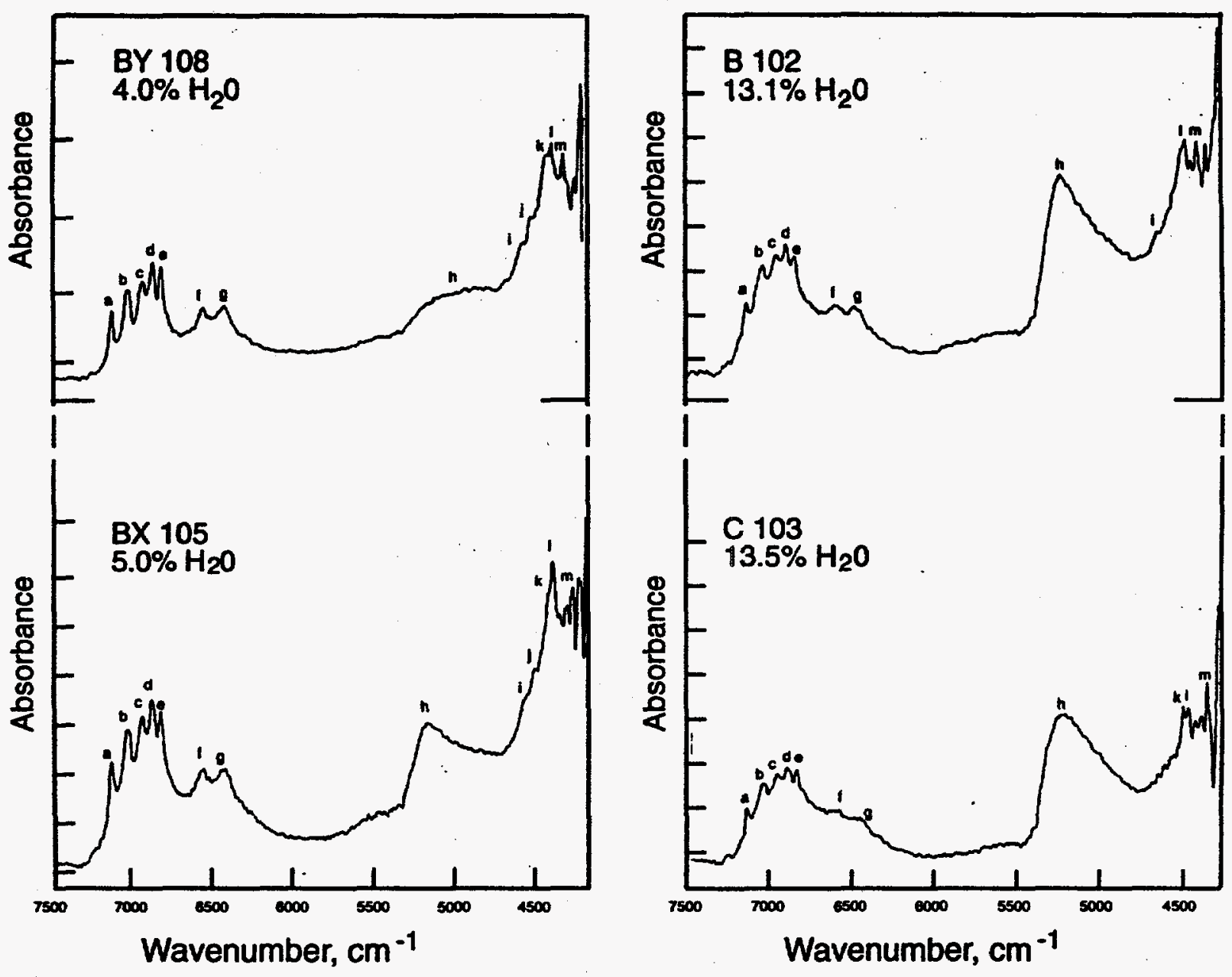
a. 7149
e. 6843
j. 4520
b. 7051
f. 6586
K. 4415
c. 6957
g. 6482
l. 4404
d. 6895
h. 5250
m. 4341
i. 4570

29506055.1 
Figure 3-2. Spectra of Tank Waste with High Moisture Content

(Tanks 241-AW-101, 241-BY-106, 241-C-102, 241-C-107, 241-C-108, 241-SY-103).
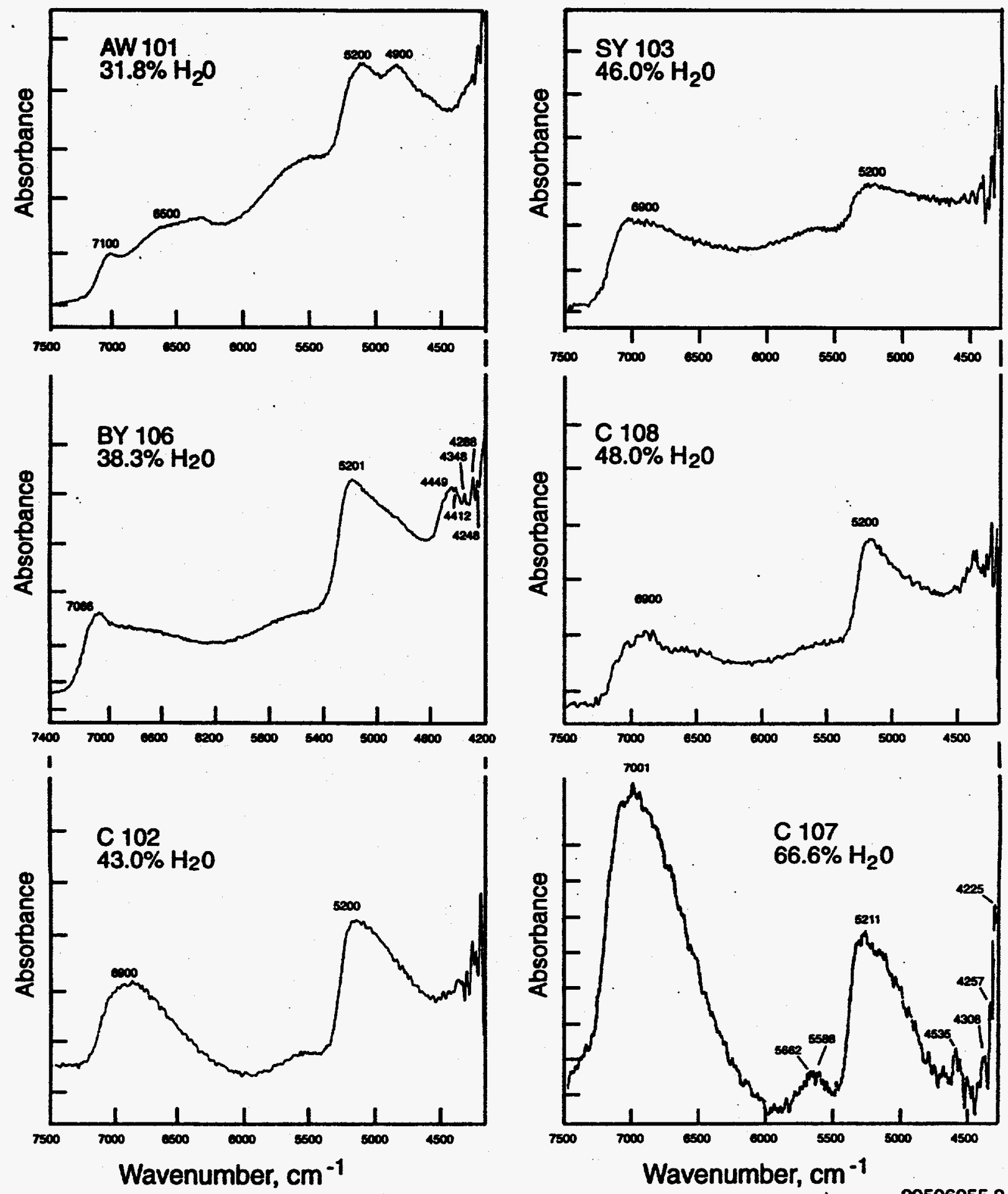

Wavenumber, $\mathrm{cm}^{-1}$

29506055.2 
Figure 3-3. Comparison of Spectra for Wet Tank Waste and Freeze-Dried Tank Waste.
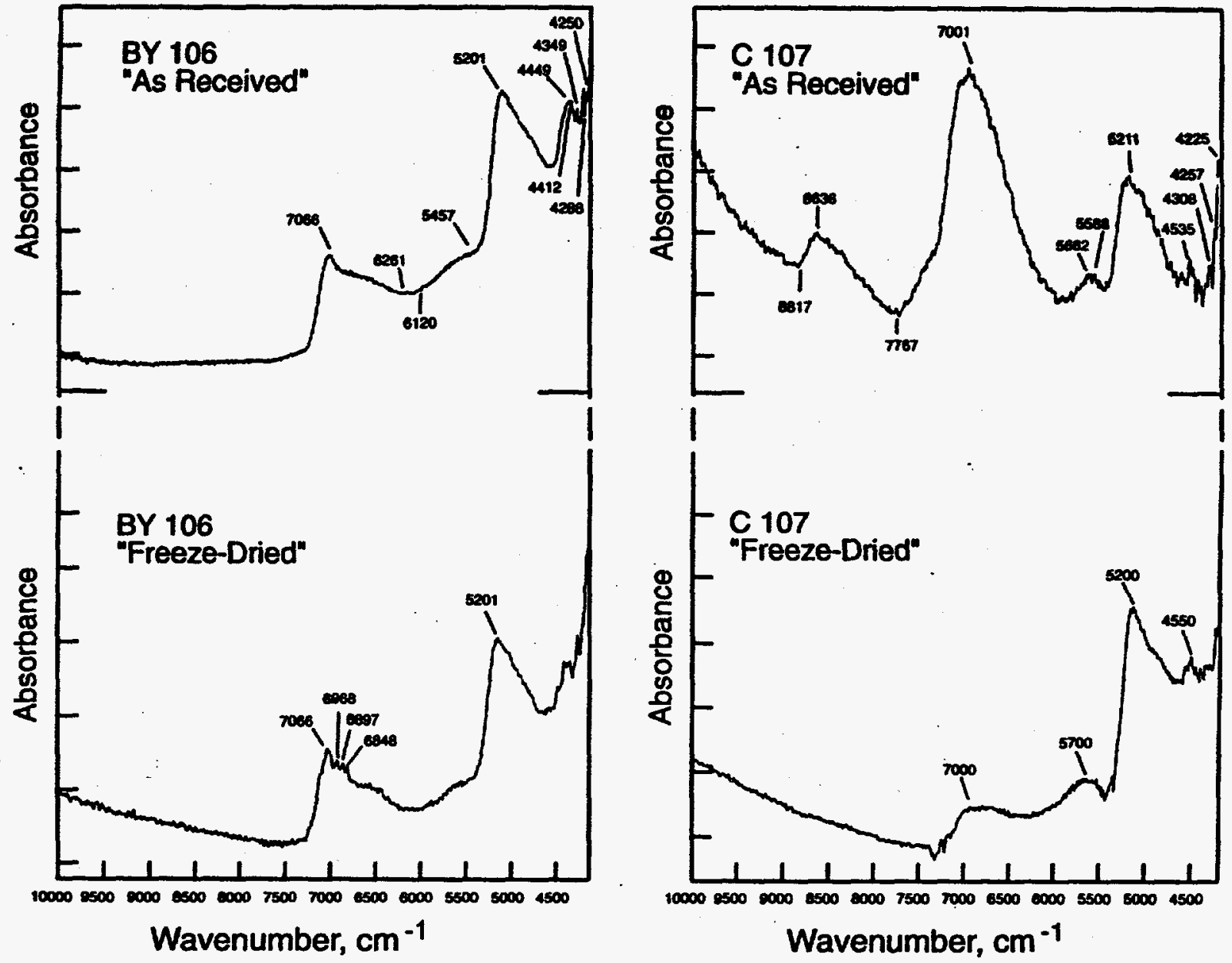

29506055.3 
The Mössbauer program represents a cooperative venture between Westinghouse Hanford Company, DOE, and the National Aeronautics and Space Administration (NASA). The contact at NASA is Dr. Richard Morris at the Johnson Space Center in Houston, Texas.

- Progress During Reporting Period. The radioactive cobalt $57\left({ }^{57} \mathrm{Co}\right)$ source has arrived onsite for hot cell testing of the Mössbauer spectrometer in a radiation field. Preliminary efforts to use actual tank waste samples for the July test are underway. Several waste samples are available for use.

LOW material was sent to Houston for Mössbauer spectroscopy. Both of the LOW materials were found to contain magnetic iron as shown by the hyperfine splitting of the spectrum. However, the LOW iron shows a significantly different spectrum from the waste simulants and it should still be possible to detect iron in the waste.

A draft report for the work done using waste simulants is being prepared. The report should be available for comment in early July. Work continues at NASA on improving the effectiveness of the Mössbauer probe. The improvements are expected to lower the noise levels and make the probe more rugged.

- Planned Work for Subsequent Months. The hot cell test using actual tank waste samples is scheduled for July. A report on the results of simulant testing will be completed. An initial tank for testing of the Mössbauer probe will be selected.

- Problem Areas and Actions Taken. Since the LOW materials contain iron, it may be difficult to detect any other iron in the tank waste. However, the iron in the LOW material does look very different from the iron in the tank simulants.

- Milestone Status.

- July 29, 1995. Westinghouse Hanford Company initiates hot cell testing of the Mössbauer tank probe using ferrocyanide tank waste samples. This milestone was slipped from April 30 because of delays in testing at NASA.

- September 30, 1995. Westinghouse Hanford Company completes an in-tank test of the Mössbauer probe in a LOW in one of the ferrocyanide tanks. This milestone was rescheduled from July 31 because of delays in hot cell testing.

- September 30, 1995. Westinghouse Hanford Company issues a report, available for public distribution, on the Mössbauer spectroscopy program results for FY 1995.

Scanning Electron Microscopy. Chemical and physical properties of ferrocyanide tank waste are being determined to accurately assess the waste for safety and inventory purposes. Analyses indicating the presence or absence of key chemical components--including $\mathrm{CN}^{-}, \mathrm{Na}$, $\mathrm{Fe}, \mathrm{Ni}$, and $\mathrm{Cs}$--can be used to characterize the tank waste and to assess whether the waste 
can be stored safely until retrieval for final disposal. Measurements that allow examination of possible correlations of chemical composition and physical properties, such as particle and crystallite size, may provide additional information on how the waste may have changed with time and facilitate comparisons of real waste properties with those determined earlier for waste simulants.

Scanning electron microscopy (SEM), coupled with backscattered electron detection and energy dispersive X-ray spectroscopy (EDS), provides a method uniquely capable of providing particle size, chemical composition, and particle morphology information in a single measurement. Recent developments in instrumentation computer control, digital data acquisition, and light element $\mathrm{X}$-ray detection have significantly enhanced the utility of this technology for particle characterization applications. Further refinements in integrated computer software and firmware now enable rapid collection, processing, and storage of large volumes of chemical and numerical data. Through these instrumentation and data processing enhancements, SEM micro-characterization has evolved into a new and potentially powerful methodology for the characterization of ferrocyanide and organic tank waste.

- Progress During Reporting Period. Initial set-up and installation of the Personal SEM $^{1}$ system was completed on June 7, 1995. The SEM, instrument control and data processing computers, and associated input/output (1/O) peripherals were located in Building 622G. Specimen preparation equipment to support the SEM were located in an adjacent trailer. The SEM systems will remain at these locations during acceptance testing, method development, and simulant analysis phases of this activity.

Unacceptable performance in the Personal SEM ${ }^{\text {TM }}$ specimen stage subsystems, the image distortion correction subsystem, and the disk I/O subsystems noted during initial tests in March 1995 were corrected. The defective turbomolecular vacuum pump was replaced and an initial SEM magnification calibration was performed. The replaced turbomolecular pump began to exhibit symptoms of bearing failure within one week of the June 7 installation. Pump replacement is now being arranged with the vendor. Final tests of magnification and imaging accuracy cannot proceed until the vacuum system issue is resolved. Problems with saving and recalling EDS spectral data from the core SEM operating programs have also been discovered and reported to the vendor.

A trailer has been acquired and is being configured to support SEM analysis of ferrocyanide tank waste samples. This trailer will be a posted radiological zone located at the 600 Area Weather Station. Initial suggestions of 200 West radiological control personnel for SEM and trailer modifications required to facilitate radiological control protocols are being followed in the facility setup. Tentative agreement was reached with the 222-S Laboratory to provide temporary space and personnel to support ferrocyanide tank waste sample and SEM specimen preparation.

${ }^{1}$ Trademark of the R. J. Lee Group, Inc., Trafford, Pennsylvania. 
Procurement of suitable standards for quality control testing was completed. Baseline measurements using these test standards will be run when the SEM operating deficiencies are resolved. Procurement of SEM system upgrades was also initiated. These upgrades are to be installed in July 1995 and will enhance (1) SEM data transfer and archiving capabilities, (2) SEM semi-quantitative elemental analysis capabilities, and (3) SEM analysis data processing and presentation options.

- Planned Work For Subsequent Months. Critical SEM system repairs and baseline test measurements will be completed, including checkout of the SEM particle analysis applications software. This applications package will be used in the analysis of ferrocyanide tank waste. SEM system upgrades will be installed and tested. The SEM will be transferred to the radioactive trailer facility and readied for test runs with tank waste samples. Analysis of various ferrocyanide waste samples will be completed and a report prepared on FY 1995 SEM program results.

- Problem Areas and Actions Taken. Personal SEM ${ }^{\mathbf{w}}$ system failures and repairs have delayed activity milestones. All dealings with the SEM vendor, the R. J. Lee Group, Inc., are now being conducted on a formal letter basis with copies to the company president and the Instruments Division vice president.

Delay in locating a facility suitable for SEM analysis of radioactive tank waste specimens has been a major problem area, but one that now seems to be resolved. Additional personnel from the Hanford Technical Services group have taken the lead in preparing the trailer-based facility. The target date of being operational in August 1995 for the SEM system in this facility is on track.

\section{- Milestone Status.}

- May 31, 1995. Westinghouse Hanford Company installs and completes operational acceptance tests on SEM system. Installation of the R. J. Lee Group, Inc. Personal SEM $^{\text {Tx }}$ system was completed June 7, 1995. Operational acceptance tests will be completed within two weeks of final resolution of SEM vacuum system and magnification calibration issues.

- September 29, 1995. Westinghouse Hanford Company issues a report, available for public release, on SEM program results for FY 1995.

\subsubsection{Estimation of Moisture Content}

Methods for determining moisture concentrations in ferrocyanide waste tanks are being developed using sample data analyses and available surveillance systems. This is an increase in scope from the original implementation plan (Cash 1991), which did not examine moisture monitoring. Two in situ moisture monitoring technologies are currently being investigated by the Ferrocyanide Safety Program: neutron diffusion and electromagnetic induction (EMI). 
Initial development of NIR spectroscopy was completed in FY 1994 (Reich et al. 1994) at the University of Washington Center for Process Analytical Chemistry. This surface moisture monitoring technology will not be developed further by the Ferrocyanide Safety - Program. Additional moisture monitoring technologies, such as copper foil activation and fission chamber in a cone penetrometer, are being evaluated by other programs. A report examining moisture monitoring technologies was completed in April 1993 (Meacham et al. 1993).

Neutron Diffusion. Well-logging techniques, coupled with computer modeling, were developed and applied to an existing neutron probe to determine information about moisture levels, material interfaces, and other waste characteristics in the ferrocyanide tanks. Using the knowledge gained from computer modeling, in situ measurements, and experimental calibration data with the current in-tank liquid level neutron probe (Watson 1993), prototype moisture measurement neutron probes were developed. This system consists of three neutron probes: a near-field thermal neutron probe, a far-field thermal neutron probe, and a far-field epithermal neutron probe. This improved system would primarily be used to determine the axial moisture concentration profile within the ferrocyanide tanks.

Moisture measurement using neutron diffusion is an established technology. The technique uses a neutron source and one or more neutron detectors. The thermal neutrons reaching a detector originate as fast neutrons from the source and are slowed or absorbed by the medium. Because hydrogen atoms are effective at slowing down neutrons, the detector response is a strong function of the surrounding moisture concentration.

Two methods are generally used in the measurement of moisture concentration around wells using neutron diffusion. The first method, the moisture gauge, has a short source-to-detector spacing (near field) on the order of 0 to $10 \mathrm{~cm}$. The response of a moisture gauge is characterized by an increase in detector response with increasing moisture concentration of the surrounding medium. The second method, the neutron $\log$, often has two detectors with longer source-to-detector spacings: 20 to $50 \mathrm{~cm}$ (far field). The detectors in a neutron $\log$ arrangement exhibit a decreased response to increased moisture concentrations. The detector placed at the shorter spacing is used to correct the response of the longer-spaced detector for borehole effects.

The tank moisture measurements are taken from within LOWs. The LOWs are permanently installed sealed pipes that extend from the riser top through the tank waste to near the tank bottom. The LOWs allow axial information about the surrounding waste materials to be obtained using certain detectors.

- Progress During Reporting Period. The development of a computer code (TMAD) that reads in the available neutron probe data and provides an estimated moisture profile is nearing completion. The code will correlate the data to the detector responses expected from different possible material anomalies and moisture contents. The code input will be based on computer modeling results of expected probe responses and on measured calibration data using moisture simulants. 
A preliminary version of the code has been used to make partial moisture interpretations of the data available from prototype neutron probe tank scans, and the results are shown in Figures 3-4, 3-5, and 3-6. Figure 3-4 shows the raw countrate data obtained with each of the prototype probes in the waste region of tank 241-BY-104. Figure 3-5 shows the preliminary moisture interpretation of the data produced by the TMAD code. The code is predicting about $17 \mathrm{wt} \%$ moisture in the saltcake and about $30 \mathrm{wt} \%$ moisture in the sludge. The moisture prediction in the saltcake region of the tank agrees with analyses of two auger samples (15 and $17 \mathrm{wt} \%$ water) taken from this tank (Neskas and Borsheim 1993).

Occasional spurious moisture predictions can be seen in the interpretation, that should be corrected by planned code changes. Moisture interpretations in the air/saltcake (not shown) and saltcake/sludge interface regions are not currently reliable because of insufficient modeling of these regions. Figure 3-6 shows the code prediction of the air annulus thickness between the LOW and surrounding waste. The code estimates that a 6-cm-thick air gap slowly reduces to essentially no air gap below the surface at about $12.5 \mathrm{~m}$.

Based on computer modeling and test measurements using the prototype probes, two final field unit probes (a thermal and epithermal) are being assembled. These field unit probes will each contain near-field and far-field detectors. The design of these probes should increase the accuracy of the moisture calibration in a high gamma field and will reduce the required source handling and data collection times.

Figure 3-4. Neutron Probe Scans of Tank 241-BY-104 Waste.

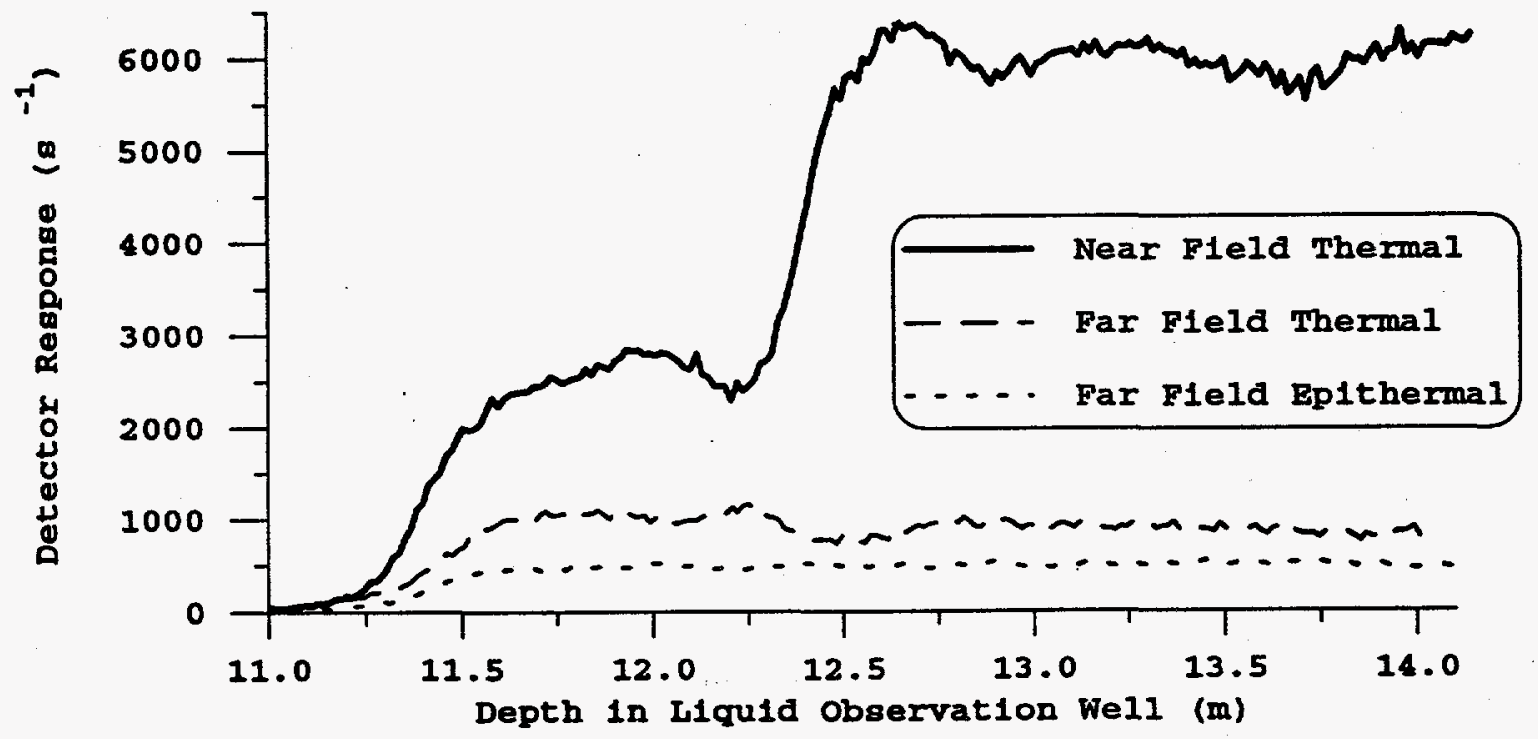


Figure 3-5. Moisture Profile in Tank 241-BY-104 Waste.

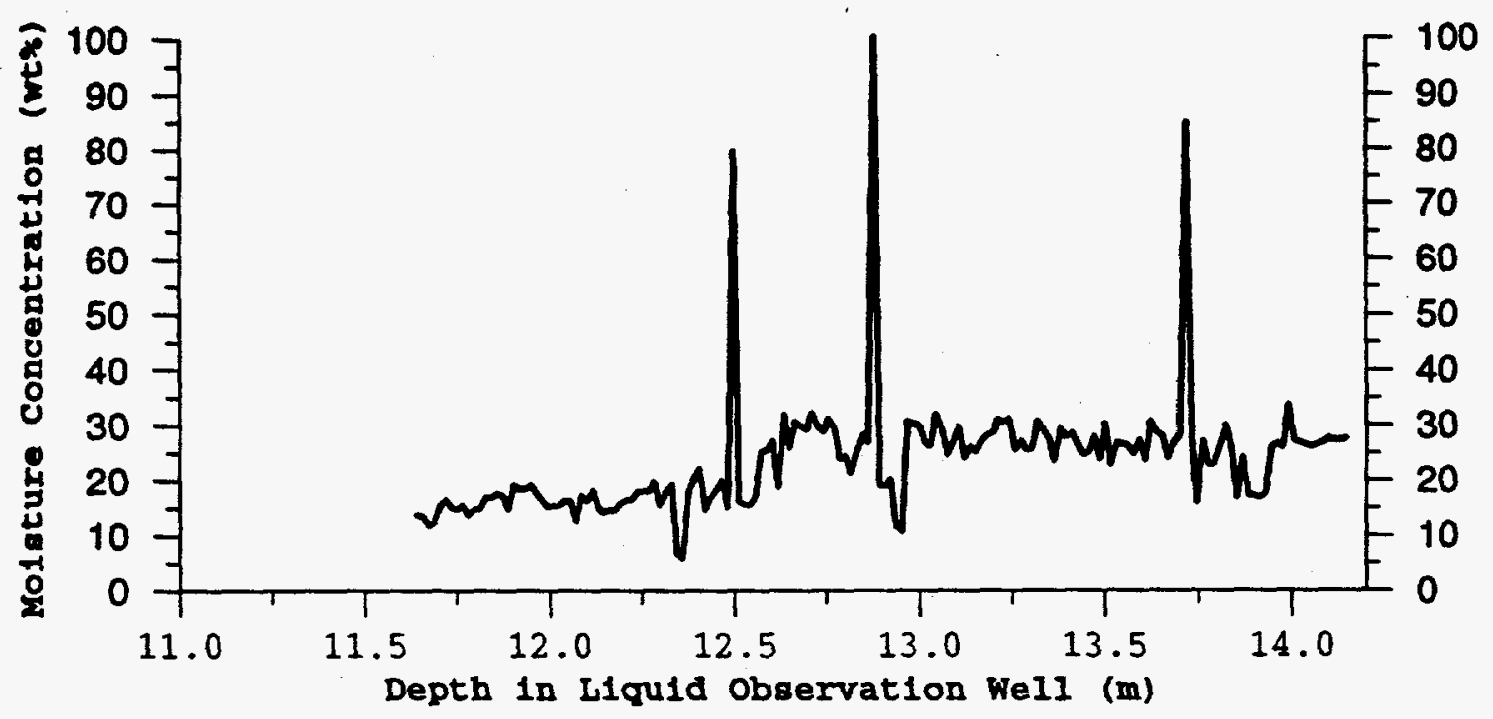

Figure 3-6. Air Annulus Profile of Tank 241-BY-104.

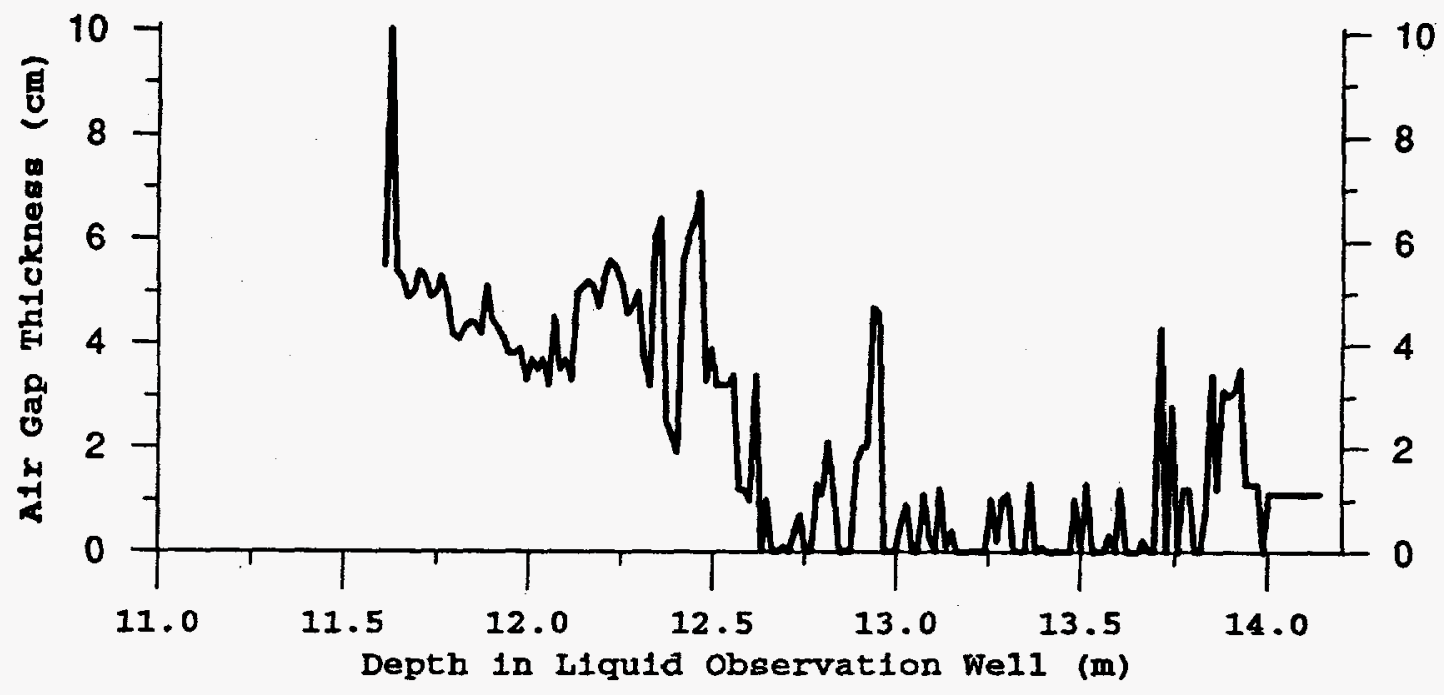


Based on computer modeling results, a neutron moisture probe for in-tank surface application has been designed. Surface moisture concentration may be considered to be more important than subsurface moisture because most credible reaction initiators would occur at the waste surface (Meacham et al. 1995b). Modeling results suggest that such a probe, lowered through a riser to the waste surface, would be quite sensitive to the moisture concentration in the top $14 \mathrm{~cm}$ of saltcake.

A new casing material and installation method for the LOWs has been developed to enhance the probe responses to the moisture content of the surrounding waste. Two types of S-type fiberglass materials were tested for use as the LOW casing material. The two types of fiberglass consisted of a filament wound fiber with Dow Epoxy Resin $331^{1}$ and a bi-directional cloth with Derakane ${ }^{1}$ 411-C-40 Vinyl Ester Resin. Tube samples of each type of fiberglass were exposed to a simulated waste tank environment consisting of corrosive chemicals, high-gamma radiation, and elevated temperatures. The physical properties of the exposed and unexposed samples were compared to determine the effects of the waste environment. There was very little change in the measured physical properties between the exposed and unexposed samples. Either type of fiberglass can be used as the LOW casing material.

A new method of installing the LOWs has been incorporated into the new LOW design. More accurate moisture probe readings can be obtained by using an insertion method that will not disturb the surrounding waste. This installation method is a modification of the ultra-high pressure water system currently used to install instrument trees (Hertelendy 1993). Modifications required that the feed water line be removable and reusable and that the borehead act as the bottom plug after installation. The ultra-high pressure water borehead system was modified and tested to meet these requirements.

- Planned Work for Subsequent Months. The assembly, testing, and calibration of dual-detector, optimized field probes will be completed. The development of an automated data moisture interpretation routine will be completed. A test fixture will be constructed for determining the responses of both the neutron and electromagnetic induction probes to air gaps between the LOW and surrounding waste.

- Milestone Status.

- December 30, 1994. The Center for Process Analytical Chemistry, at the University of Washington, completes Phase 3 surface monitoring work and provides a report. Initial development of the NIR work was completed in September 1994, and a report was issued December 29, 1994 (Reich et al. 1994).

${ }^{1}$ Dow 331 Epoxy and Derakane are trademarks of the Dow Chemical Company, Midland, Michigan. 
- September 30, 1995. Complete installation and deployment of the first phase of the neutron moisture monitoring system and initiate monitoring.

- September 30, 1996. Complete installation and deployment of the neutron moisture monitoring system for routine monitoring in ferrocyanide tanks.

Electromagnetic Induction Probe. The purpose of this task is to deploy the EMI probe in the LOWs and possibly near the waste surface to measure moisture concentration. EMI probes operate by creating a magnetic field that induces current in a conductive medium. This induced current can be measured and is related to the media conductivity. The higher the electrical conductivity, the higher the free moisture content in the tank waste.

The EMI probe is designed with four separate coils of wire that can be either exciting coils or sensing coils. The present configuration uses one coil as the exciting coil and three coils, at different distances, as the sensing coils. This configuration allows three different depths of penetration during one scan. The electronics can be programmed to use four frequencies during one scan, so the information acquired will be four frequencies at three different coil spacings. This will be useful in separating the environment near the LOW from the environment far from the LOW. Two different EMI probes have been built, with different coil spacing and turns per coil, to determine in-tank responses.

Two areas of engineering activity apply to measurement of free moisture in the high-level waste tanks: (1) EMI measurement of absolute conductivity of the waste medium; and (2) determination of the electrical conductivity as a function of free moisture content of ferrocyanide or organic waste. Measurement of absolute conductivity is being studied using finite-element modeling of the EMI probe geometry. The modeling is being performed by Washington State University (WSU) using EDDY-C, a proprietary code, and in-house using EMIP, an electromagnetic induction program developed at Oak Ridge National Laboratory during the early 1970 's.

- Progress During Reporting Period. Finite element EMI probe simulations were completed this quarter at WSU. Results were used to choose two different EMI probes for construction. Initial procurement of EMI hardware and analysis software has been completed. Electrical conductivity calibration standards were designed and are being constructed by Pacific Northwest Laboratory (PNL). An EMI functionality standard for use in the field has been designed and is presently being constructed by PNL.

Pacific Northwest Laboratory provided benchmark EMI measurements using their EMI equipment. These data will be used with the EDDY-C code and the EMIP code to define the normalization procedure to compare EMI measurements with EMI calculations. 
Small-scale tests using waste simulants were completed this quarter. Simulants tested include T Plant, U Plant, In Farm, SY-101 with organic, SY-101 without organic, and a potassium nitrate solution. Preliminary results measured simulant electrical conductivity as a function of moisture and temperature.

- Planned Work for Subsequent Months. The EMI probe will be deployed in several tank LOWs for comparison moisture measurements with the neutron probe. A progress report on the EMI probe project, equipment, data collection and analysis methods will be prepared. EMI probe modeling will continue at WSU with the goal of: (1) defining the EMI frequency response with increasing conductivity; (2) determining the depth of penetration into the waste scanned with different coil spacings; and (3) standardizing the interpretation of data from portable and laboratory calibration standards.

- Problem Areas and Action Taken. A new dedicated surveillance van will not be procured for the EMI probe; therefore, measurements will be made using the existing vans. The EMI draw works will be mounted on the front bumper, and the van power supplies will be used.

- Milestone Status.

- May 30, 1995. Westinghouse Hanford Company acquires an EMI system compatible with surveillance van application. This milestone was completed on April 7, 1995. Procurement of a surveillance van specifically for EMI was not approved; consequently, acquisition of the EMI system fulfills this milestone.

- September 30, 1995. Westinghouse Hanford Company issues a report, cleared for public release, describing the FY 1995 engineering testing of the EMI moisture monitoring system. The report will describe the equipment and procedures necessary for deployment of the EMI probe in tanks for routine monitoring of moisture content in ferrocyanide and organic tanks.

\subsubsection{Moisture Retention Properties of Ferrocyanide Sludge and Saltcake Simulants}

The moisture content of ferrocyanide sludge is very critical in preventing exothermic ferrocyanide/nitrate-nitrite reactions. Studies are underway to evaluate the moisture retention properties of ferrocyanide tank sludge and saltcake simulants as they relate to possible waste tank leaks, tank stabilization by pumping, and possible evaporation from exposed surfaces. Previous work (Epstein et al. 1994) has shown that ferrocyanide sludge cannot dry sufficiently to be chemically reactive during interim storage, either globally or locally. Dryout mechanisms evaluated included global evaporation, removal of liquid by leakage or pumping, boiling as a result of hot spots, and enhanced surface evaporation from hot spots. Current work is focusing on moisture retention in saltcake material, especially after a tank has been interim stabilized. 
Modeling calculations are being performed to estimate the moisture-retaining capability of ferrocyanide waste in typical Hanford Site tank systems. The effort focuses on evaluating the impact of consolidation and surface evaporation processes. Computer models are employed to estimate the moisture retention within the matrix and to determine surface drying of sludge and saltcake waste. To accomplish these objectives, the hydraulic properties of actual sludges and saltcake porous media must be compared with tested waste simulants, and their physical properties must be correlated.

Modeling work is presently examining the resistance of saltcake waste to gravity drainage and surface evaporation. Under gravity's influence, saturated saltcake will drain when liquid is pumped out and when a tank is stabilized. In contrast, sludge does not readily drain and the interstitial liquid must be expelled by consolidation, usually caused by an overburden. Because saltcake drains when stabilized, it is more subject to potential drying at the surface as a result of moisture evaporation.

- Progress During Reporting Period. A simplified model for the steady evaporation of moisture from a saltcake waste surface was devised based on principles of unsaturated liquid flow in a porous matrix. Even in a closed tank, moisture is continually evaporating from the waste surface because of the heat load and then recondensing on the cooler tank-wall surfaces. To bound the greatest drying condition, the model assumes that all heat transfer occurs by evaporation. However, evaporation cannot occur at a rate that exceeds how rapidly liquid (brine) can flow upward to maintain the surface moisture. When moisture is evaporated at the surface of an unsaturated porous medium, capillary forces draw liquid upward against gravity to maintain the volumetric liquid content.

The model is one-dimensional and does not yet account for diffusion of water vapor through the interstices. The model also neglects accumulation of salts on the waste surface and the resulting effects on local hydraulic properties. The model as conceptualized represents only a first step in connecting evaporation with interstitial liquid flow controlled by capillarity. Liquid flow and water vapor movement in the unsaturated zone under non-isothermal conditions in the waste profile still need to be fully coupled to accurately assess the potential for dryout. The possibility of deliquescence near the cooler surface has not been accounted for, either. This hygroscopic phenomenon depends on the extent that the saturation vapor pressure is lowered by the particular salt composition near the surface.

Depending on the thermal gradient in the profile, upward vapor flow may nearly balance a downward flow of liquid driven by gravity. Thus, the excess liquid condensed near the surface may produce a net downward liquid flow. This behavior would tend to increase the moisture content near the surface over that of the static equilibrium condition. The present model cannot examine that possibility until additional improvements are incorporated. To accomplish further model development, better estimates of hydraulic parameters and the dependence of water vapor pressure on the salt composition of the waste are required. 
- Planned Work for Subsequent Months. Modeling will be advanced to consider non-isothermal coupling of liquid flow and water vapor diffusion in an unsaturated waste profile. This new work is intended to test the validity of the simplified modeling approach explained above. The possible forcing of liquid upward from sludge into saltcake by consolidation caused by stabilization will also be evaluated for importance.

The modeling work examines moisture loss through drainage and evaporation. Therefore, the separate task on evaporation has been included in the modeling described above, and only one report will be published for this task. Consequently, the milestone on moisture loss as a function of relative humidity has been canceled.

- Problem Areas and Actions Taken. None.

- Milestone Status.

- September 29, 1995. Pacific Northwest Laboratory issues a report, cleared for public release, on FY 1995 work on waste moisture modeling activities.

- September 29, 1995. Westinghouse Hanford Company issues a publicly available report evaluating water loss from sludge and saltcake as a function of relative humidity and gravity draining. This milestone has been deleted and notification of this change is hereby provided in accordance with Section 3.7 of the program plan (DOE 1994b).

\subsection{CHEMICAL REACTION STUDIES}

"The schedule for the program on study of the chemical properties and explosive behavior of the waste in these tanks is indefinite and does not reflect the urgent need for a comprehensive and definitive assessment of the probability of a violent chemical reaction. The study should be extended to other metallic compounds of ferrocyanide that are known or believed to be present in the tanks, so that conclusions can be generalized as to the range of temperature and other properties needed for a rapid chemical reaction with sodium nitrate. "

Chemical reaction studies on ferrocyanide waste simulants are being conducted by Westinghouse Hanford Company, Fauske and Associates, Inc. (FAI), PNL, and Los Alamos National Laboratory (LANL). Westinghouse Hanford Company and PNL have produced flowsheet simulant materials for testing and characterization. FAI is conducting adiabatic calorimetry and propagation tests on these same flowsheet materials and on stoichiometric mixtures of pure sodium nickel ferrocyanide and sodium nitrate/nitrite. The test program at LANL was completed in FY 1993. 


\subsubsection{Chemical Reaction Studies at Pacific Northwest Laboratory}

Chemical reaction studies are continuing at PNL using flowsheet simulant materials. Waste studies addressing DNFSB Recommendation 90-7.5 are being conducted to determine the following: (1) the aging effects (hydrolysis and radiolysis) from more than 35 years of storage in the tanks; (2) the speciation of cyanides found in the actual tank waste; (3) the ability of waste to take up cesium; (4) the correlation of waste simulant and actual waste properties, and (5) modeling calculations to predict the moisture-retaining capability of ferrocyanide waste in a typical tank system (this work is reported in Section 3.4.3).

\section{- Progress During Reporting Period.}

Microconvection Modeling. The focus of the microconvection modeling work was to determine: (1) if caustic solutions could penetrate into deep ferrocyanide sludge layers; and (2) whether hot spots could form if cesium were retrograde soluble. Modeling showed that caustic solutions could indeed penetrate more than a meter deep into ferrocyanide sludge (McGrail 1994). Experiments on cesium solubility (Rai et al. 1994) showed that cesium was not retrograde soluble and the end result of microconvection would be to disburse the cesium. Consequently, microconvection modeling work was completed in FY 1994 and a report was issued in November 1994 (McGrail 1994). However, because of a tracking oversight, completion of this task was not reported in the December 1994 and March 1995 quarterly reports (Meacham et al. 1995c, Cash et al. 1995). Completion of this milestone is reported here to correct this oversight.

Solubility of Sodium-Cesium Nickel Ferrocyanide Compounds. A report summarizing the influences of cesium, sodium, nickel, and ferrocyanide on the solubility of cesium nickel ferrocyanide was published at the end of FY 1994 (Rai et. al. 1994). Tests indicated that cesium did not exhibit retrograde solubility (i.e., decreasing solubility with increasing temperature). The FY 1994 results answered the main concern over solubility (i.e., whether cesium was retrograde soluble) and little technical reason existed to continue this work into FY 1995. Therefore, the FY 1995 milestone on ferrocyanide solubility has been canceled.

Aging Studies. Hydrolysis experiments conducted at $100^{\circ} \mathrm{C}$ were completed this quarter. Samples of In Farm 1B ferrocyanide simulant were exposed to various temperatures and gamma dose rates to determine the effect of temperature and dose rate on hydrolysis. Ammonia concentration as a function of time for different temperatures at an incident gamma dose rate of $1 \times 10^{5} \mathrm{Rad} / \mathrm{h}$ is plotted in Figure 3-7. The data show a near linear relationship, and a least squares line fit is drawn through the data points. 
A global rate constant for $\mathrm{NH}_{3}$ production at each temperature can be obtained from the plots. These rate constants do not directly represent the rate of ferrocyanide hydrolysis because the rate of $\mathrm{NH}_{3}$ radiolysis is included. A linear Eyring plot (Figure 3-8) is obtained from which it is determined that the change in enthalpy = $32.5 \mathrm{kcal} / \mathrm{mole}$ and the change in entropy $=18.6 \mathrm{cal} /{ }^{\circ} \mathrm{K} /$ mole for the global process.

Ammonia production as a function of time for different gamma dose rates at $90^{\circ} \mathrm{C}$ is shown in Figure 3-9. Again, the data can be approximated by straight lines from which global rate constants can be obtained. The plot of global rate constant versus gamma dose rate (Figure 3-10) is linear (slope $=2.8 \times 10^{-8}$ moles $\bullet h / L \bullet$ day $\bullet$ Rad, intercept $=7.9 \times 10^{-4}$ moles/L-day): The intercept, which gives the rate constant in the absence of a gamma dose, is approximately the average rate constant $\left(6.7 \times 10^{-4}\right.$ moles/L•day) observed in the control experiments for runs at $90^{\circ} \mathrm{C}$.

Results to date from the long-term experiments at $\mathrm{pH} 10$ and $60^{\circ} \mathrm{C}$, irradiated at $4.5 \times 10^{4} \mathrm{Rad} / \mathrm{h}$, are shown in Figures 3-7 through 3-11. Based on the observed $\mathrm{NH}_{3}$ concentration, hydrolysis has converted at least $14 \%$ of the cyanide in the In Farm simulant to $\mathrm{NH}_{3}$. The actual extent of hydrolysis is probably higher than this because $\mathrm{NH}_{3}$ is slowly destroyed in the gamma field. The radiolysis of $\mathrm{NH}_{3}$ may explain the slightly lower $\mathrm{NH}_{3}$ concentration in the four-month sample. The actual extent of hydrolysis will be determined by FTIR analysis of the soluble and insoluble ferrocyanide next quarter.

Speciation of Ferrocyanide in Actual Wastes. Actual waste samples from tanks 241-C-109 and -C-112 were analyzed for cyanide content by FTIR this quarter. The radiocesium was removed by ion exchange prior to removing samples from the hot cells for FTIR analysis. The cyanide content of these samples was analyzed on the dissolved sample prior to ion exchange and on the solution after ion exchange.

Table 3-4 presents the results from determination of cyanide concentrations for the total cyanide method (before ion exchange), the FTIR method (after ion exchange), and percent recovery of cyanide. Cyanide recovery for these waste samples ranged from 87 to $106 \%$. The excellent agreement between these two methods demonstrates that the ion exchange method does not affect the recovery of cyanide and will not affect the analysis of cyanide in ferrocyanide waste samples.

An FTIR spectrum of an actual ferrocyanide waste sample (tank 241-C-112, Core 36, Composite $2 \mathrm{C}$ ) is shown in Figure 3-12. This shows that the only cyanide species present in these solutions is the ferrocyanide complex (infrared peak located at $\left.2,038 \mathrm{~cm}^{-1}\right)$. If other cyanide species were present, such as ferricyanide $\left(2,116 \mathrm{~cm}^{-1}\right)$, free cyanide ion $\left(2,080 \mathrm{~cm}^{-1}\right)$, nitroprusside $\left(2,141\right.$ and $\left.1,935 \mathrm{~cm}^{-1}\right)$, etc., they would be observed in this spectrum. 
Figure 3-7. Least Squares Fit of $\mathrm{NH}_{3}$ Production as a Function of Time for Temperatures of $50,70,80,90$, and $100{ }^{\circ} \mathrm{C}$.

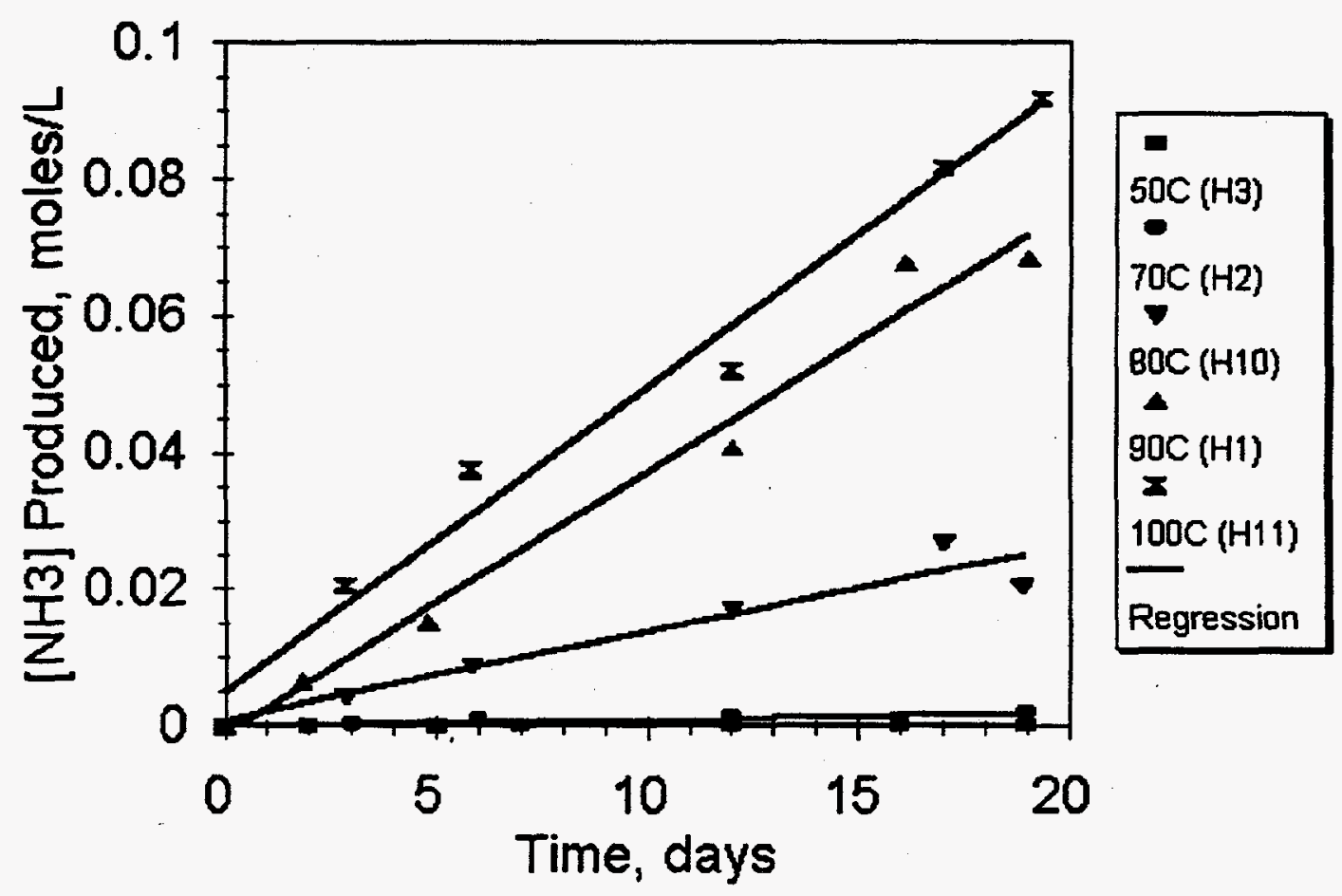

Figure 3-8. Eyring Plot for $\mathbf{N H}_{3}$ Production as a Function of Temperature.

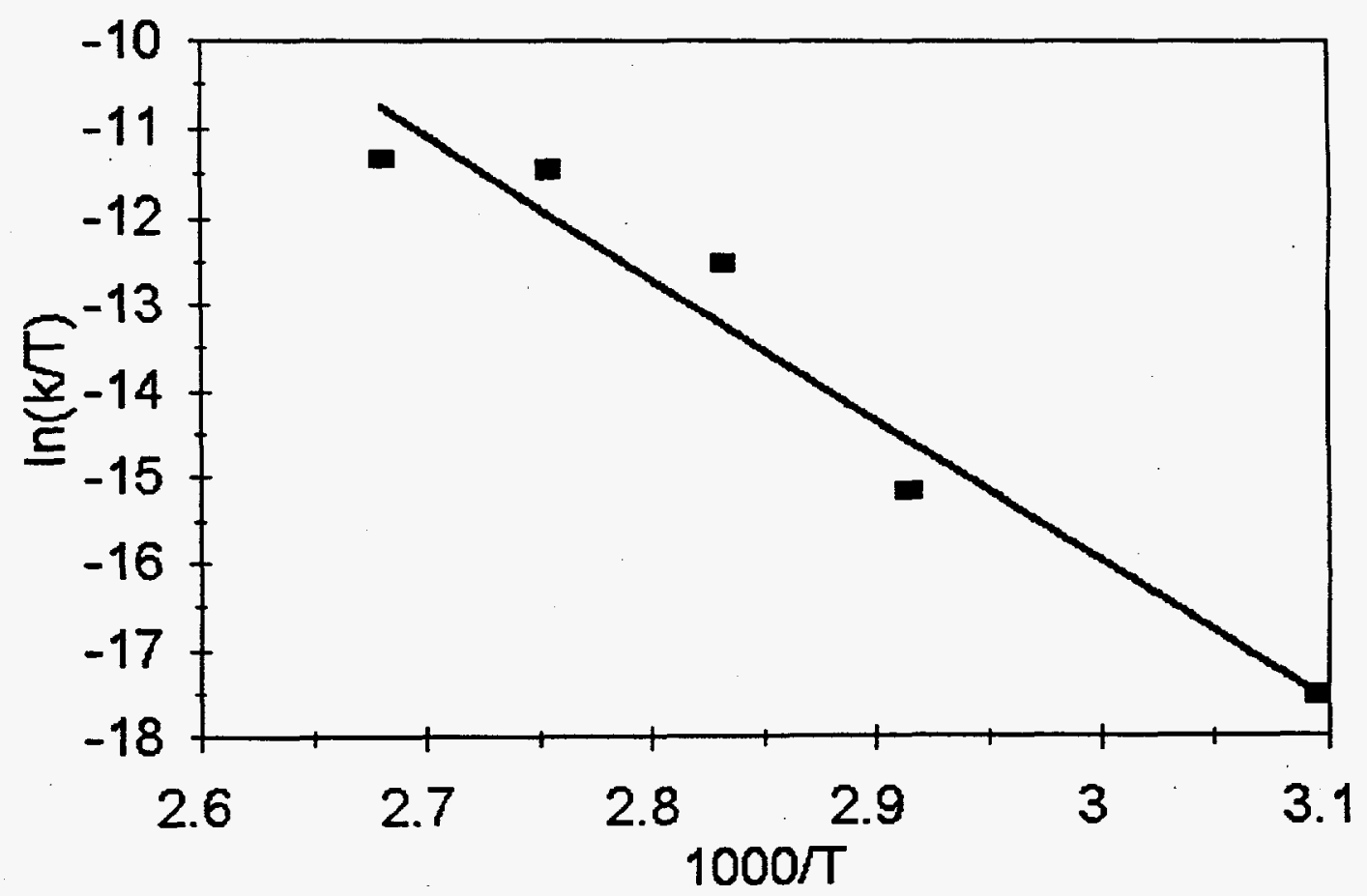


Figure 3-9. Least Squares Fit of $\mathrm{NH}_{3}$ Production as a Function of Time for Various Gamma Dose Rates.

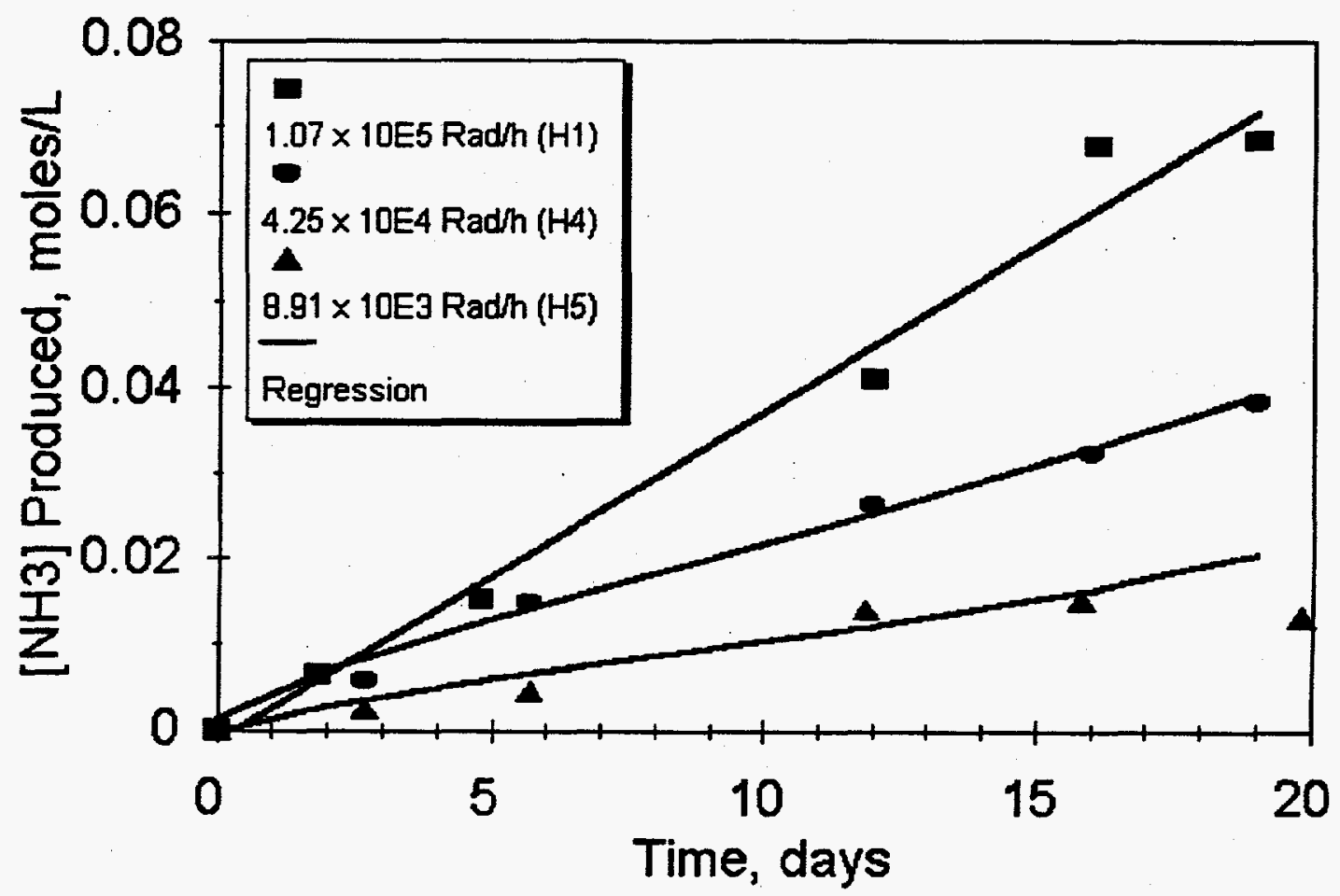

Figure 3-10. Ammonia Production as a Function of Gamma Dose Rate at $90^{\circ} \mathrm{C}$.

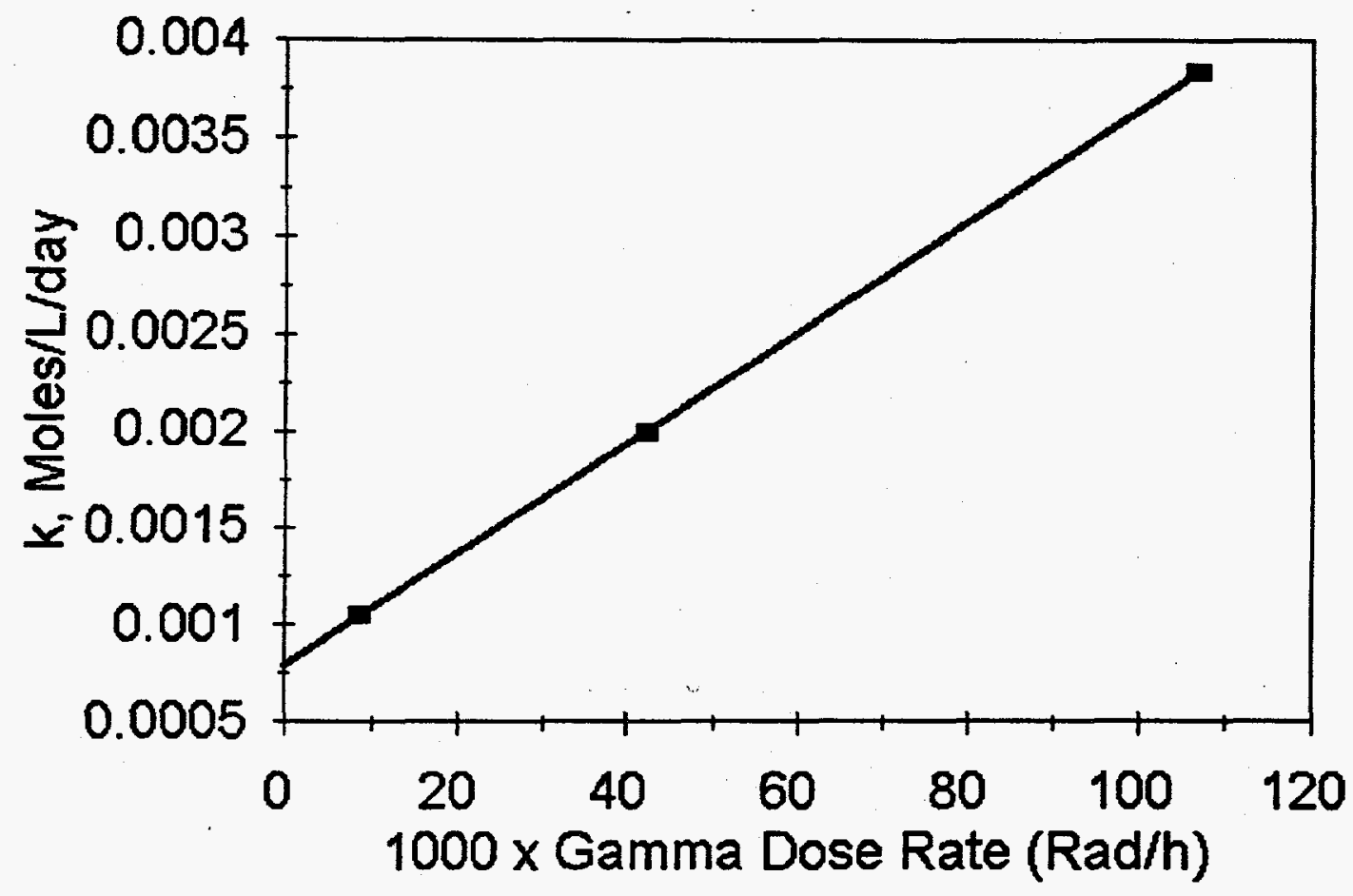


Figure 3-11. Ammonia Production as a Function of Time at $\mathrm{pH} 10,60^{\circ} \mathrm{C}$ and a Gamma Dose Rate of $4.5 \times 10^{4} \mathrm{Rad} / \mathrm{h}$.

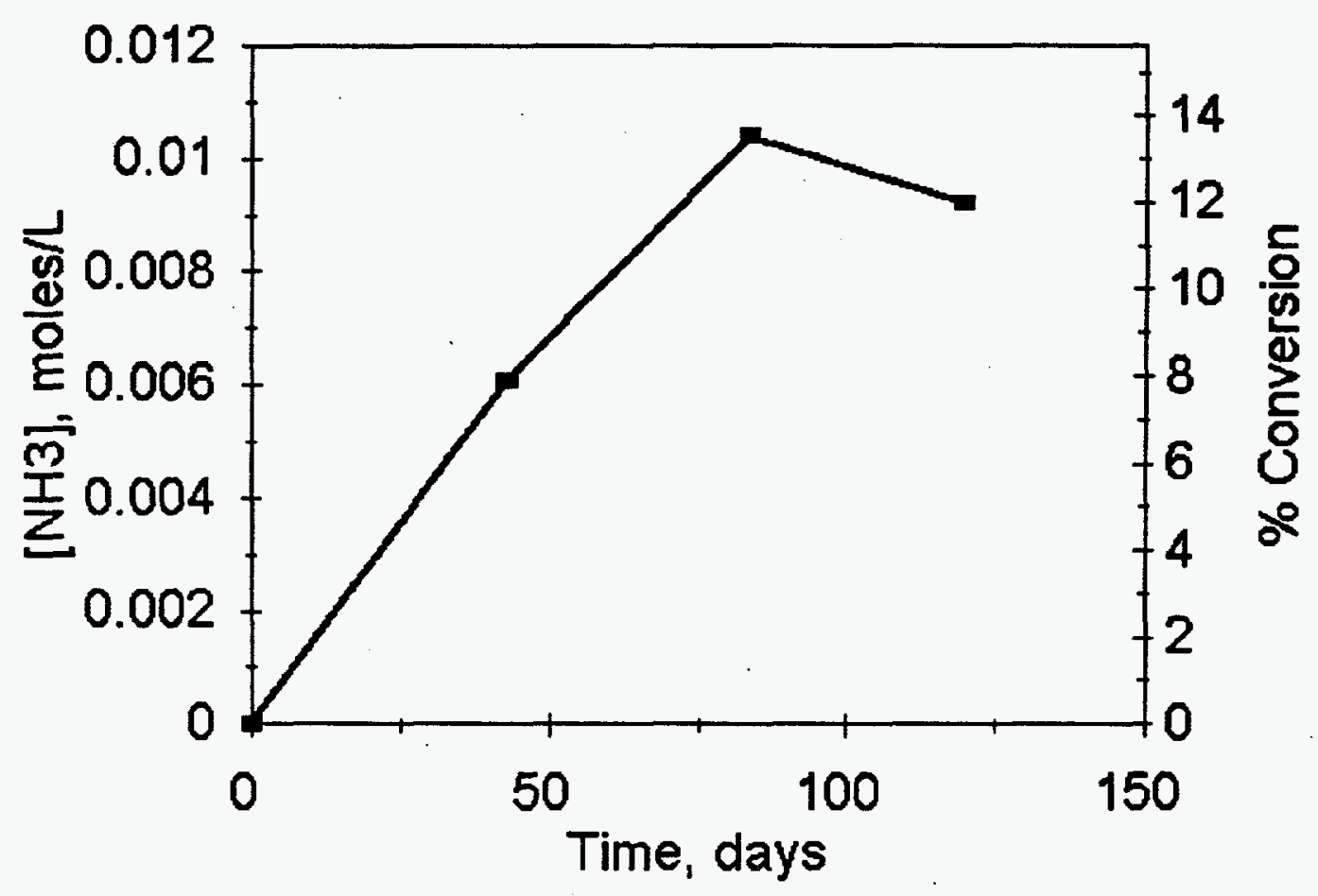


Table 3-4. The Effect of Ion Exchange on Cyanide Analyses for Samples from Tanks 241-C-109 and 241-C-112.

\begin{tabular}{|l|c|c|c|}
\hline Sample & $\begin{array}{c}\text { Total Cyanide* } \\
(w t \%)\end{array}$ & $\begin{array}{c}\text { FTIR** } \\
(w t \%)\end{array}$ & $\begin{array}{c}\text { Recovery } \\
(\%)\end{array}$ \\
\hline Tank C-112, Core 34, Segment 2B & 0.51 & 0.52 & 101 \\
\hline Tank C-112, Core 34, Segment 2C & 0.73 & 0.73 & 101 \\
\hline Tank C-112, Core 34, Segment 2C & 0.62 & 0.67 & 106 \\
\hline Tank C-112, Core 36, Composite 2C & 0.99 & 0.86 & 87 \\
\hline Tank C-109, Core 49, Composite 1D & 0.58 & 0.60 & 103 \\
\hline
\end{tabular}

* Cyanide concentrations prior to ion exchange were measured by total cyanide method.

** Cyanide concentrations after ion exchange were measured by FTIR method.

Figure 3-12. FTIR Spectrum of Samples from Tank 241-C-112, Core 36, Composite 2C.

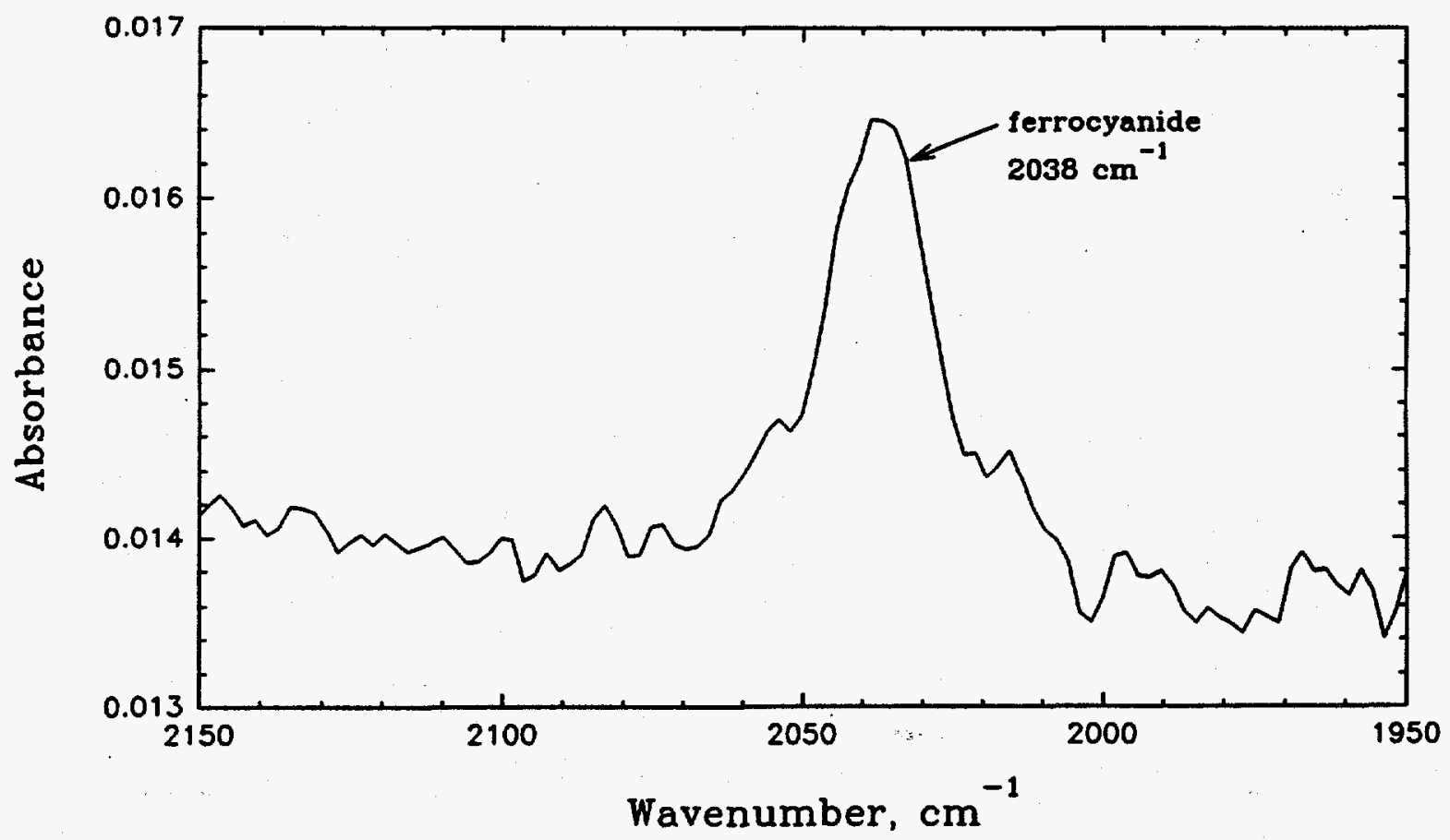


Cesium Uptake Capacity. Cesium ion exchange distribution constants $\left(\mathrm{K}_{\mathrm{d}}\right)$ were measured this quarter on U Plant 2 and In Farm 2 waste simulants. The data are presented in Table 3-5. Results from the constant sodium/cesium ratio experiments corroborate the experimental observation that In Farm 2 simulant is a better cesium exchanger than U Plant 2 simulant. The maximum cesium capacities of the simulants were calculated based on these data. The U Plant 2 capacity is approximately 0.50 mole of cesium per mole of nickel ferrocyanide and the In Farm 2 capacity is approximately $\mathbf{0 . 8 0}$ mole of cesium per mole of nickel ferrocyanide.

Table 3-5. Cesium Distribution Coefficients for U Plant 2 and In Farm 2 Waste Simulants.

\begin{tabular}{|c|r|r|}
\hline Ratio of Cesium to Nickel Ferrocyanide & $\begin{array}{c}\mathrm{K}_{\mathrm{d}} \text { for U Plant 2 } \\
(\mathrm{mL} / \mathrm{g})\end{array}$ & $\begin{array}{c}\mathrm{K}_{\mathrm{d}} \text { for In Farm 2 } \\
(\mathrm{mL} / \mathrm{g})\end{array}$ \\
\hline 200 & $*-15$ & $* 80$ \\
\hline 100 & 5 & $* 86$ \\
\hline 50 & 9 & 17 \\
\hline 25 & 20 & 73 \\
\hline 10 & 30 & 170 \\
\hline 5 & 80 & 420 \\
\hline 2 & 170 & 1,000 \\
\hline 1 & 300 & 4,200 \\
\hline 0.50 & 650 & 770,000 \\
\hline 0.10 & 39,000 & 880,000 \\
\hline 0.050 & 220,000 & 500,000 \\
\hline 0.0010 & 750,000 & $1,300,000$ \\
\hline 0.0050 & 740,000 & 700,000 \\
\hline 0.0025 & 340,000 & 650,000 \\
\hline 0.0010 & 390,000 & \\
\hline
\end{tabular}

* These values are suspect; experiments to be rerun to confirm results. 
Layering experiments were also completed this quarter for the U Plant 2 simulant. Simulant, loaded to maximum cesium capacity ( 0.50 mole of cesium to mole of nickel ferrocyanide), was mixed and allowed to settle in a column. Potential layering was measured by detecting the ${ }^{137} \mathrm{Cs}$ enriched material using a gamma detector equipped with a shielded collimated slit. The settled U Plant 2 solids showed no evidence of layering.

Comparison of Simulants and Actual Ferrocyanide Waste. The elemental concentrations of simulant and actual waste were measured using inductively coupled argon plasma atomic emission spectroscopy. In Farm 2 simulant was compared with waste from tanks $241-\mathrm{C}-109$ and $241-\mathrm{C}-112$, and the results are summarized in Tables 3-6 and 3-7.

Table 3-6. Comparison of In Farm Simulant and Samples from Tank 241-C-109.

\begin{tabular}{|l|c|c|r|r|r|r|}
\hline Analyte & $\begin{array}{c}\text { In Farm Simulant, } \\
\text { Top Fraction } \\
(\mathrm{mmol} / \mathrm{g})\end{array}$ & $\begin{array}{c}\text { In Farm Simulant, } \\
\text { Bottom Fraction } \\
(\mathrm{mmol} / \mathrm{g})\end{array}$ & $\begin{array}{c}\text { C47-1D } \\
(\mathrm{mmol} / \mathrm{g})\end{array}$ & $\begin{array}{c}\text { C49-1B } \\
(\mathrm{mmol} / \mathrm{g})\end{array}$ & $\begin{array}{c}\text { C49-1C } \\
(\mathrm{mmol} / \mathrm{g})\end{array}$ & $\begin{array}{c}\mathrm{C} 49-1 \mathrm{D} \\
(\mathrm{mmol} / \mathrm{g})\end{array}$ \\
\hline $\mathrm{Al}$ & Not Added & Not Added & $7.6 \mathrm{e}-01$ & $9.6 \mathrm{e}+00$ & $4.5 \mathrm{e}+00$ & $6.7 \mathrm{e}+00$ \\
\hline $\mathrm{Ca}$ & Not Added & Not Added & $8.7 \mathrm{e}-01$ & $1.4 \mathrm{e}-01$ & $8.9 \mathrm{e}-01$ & $7.7 \mathrm{e}-01$ \\
\hline $\mathrm{Co}$ & Not Added & Not Added & $4.4 \mathrm{e}-04$ & $1.9 \mathrm{e}-04$ & $8.2 \mathrm{e}-04$ & $1.3 \mathrm{e}-03$ \\
\hline $\mathrm{Fe}$ & $6.8 \mathrm{e}-01$ & $7.2 \mathrm{e}-01$ & $8.7 \mathrm{e}-01$ & $4.1 \mathrm{e}-01$ & $4.4 \mathrm{e}-01$ & $1.3 \mathrm{e}-01$ \\
\hline $\mathrm{Ni}$ & $7.0 \mathrm{e}-01$ & $7.7 \mathrm{e}-01$ & $7.8 \mathrm{e}-01$ & $1.4 \mathrm{e}-01$ & $5.6 \mathrm{e}-01$ & $5.4 \mathrm{e}-01$ \\
\hline $\mathrm{P}$ & Not Added & Not Added & $1.4 \mathrm{e}+00$ & $1.0 \mathrm{e}-01$ & $1.1 \mathrm{e}+00$ & $3.2 \mathrm{e}-01$ \\
\hline
\end{tabular}

Table 3-7. Comparison of In Farm Simulant and Samples from Tank 241-C-112.

\begin{tabular}{|c|c|c|c|c|c|c|c|}
\hline Analyte & $\begin{array}{c}\text { In Farm } \\
\text { Simulant, } \\
\text { Top } \\
(\mathrm{mmol} / \mathrm{g})\end{array}$ & $\begin{array}{l}\text { In Farm } \\
\text { Simulant, } \\
\text { Bottom } \\
(\mathrm{mmol} / \mathrm{g})\end{array}$ & $\mid \begin{array}{c}\text { C36-1D } \\
(\mathrm{mmol} / \mathrm{g})\end{array}$ & $\begin{array}{c}\text { C34-2B } \\
(\mathrm{mmol} / \mathrm{g})\end{array}$ & $\begin{array}{c}\mathrm{C} 34-2 \mathrm{C} \\
(\mathrm{mmol} / \mathrm{g})\end{array}$ & $\begin{array}{c}\mathrm{C} 34-2 \mathrm{D} \\
(\mathrm{mmol} / \mathrm{g})\end{array}$ & $\begin{array}{c}\mathrm{C} 35-2 \mathrm{D} \\
(\mathrm{mmol} / \mathrm{g})\end{array}$ \\
\hline $\mathrm{Al}$ & Not Added & Not Added & $4.1 e-01$ & $2.4 e+00$ & $8.7 e+00$ & $3.7 e+00$ & $2.6 e+00$ \\
\hline $\mathrm{Ca}$ & Not Added & Not Added & $1.8 e+00$ & $1.1 e+00$ & $1.1 e+01$ & $2.5 e+00$ & $6.1 e-01$ \\
\hline $\mathrm{Co}$ & Not Added & Not Added & $4.8 e-04$ & $7.9 e-04$ & ND & $1.7 e+00$ & $3.4 e-04$ \\
\hline $\mathrm{Fe}$ & $6.8 e-01$ & $7.2 e-01$ & $3.8 \mathrm{e}-01$ & $5.4 e-01$ & $1.4 e+01$ & $1.8 e+00$ & $1.2 \mathrm{e}+00$ \\
\hline $\mathrm{Ni}$ & $7.0 e-01$ & $7.7 e-01$ & $8.7 e-01$ & $6.5 e-01$ & $1.3 e+01$ & $1.7 e+00$ & $4.3 e-01$ \\
\hline$\overline{\mathbf{P}}$ & Not Added & Not Added & $1.3 e+00$ & $9.2 e-01$ & $1.4 \mathrm{e}+01$ & $3.2 e+00$ & $1.0 e+00$ \\
\hline
\end{tabular}


Based on historical records, the radioactive waste in tank 241-C-109 is comprised of layers of about $38 \mathrm{~kL}$ of first-cycle bismuth phosphate waste, $167 \mathrm{~kL}$ of ferrocyanide waste, and $38 \mathrm{~kL}$ of PUREX cladding removal waste and evaporator bottoms. Thus, the ferrocyanide waste would be expected to be sandwiched between the bismuth phosphate waste and cladding waste. Scavenging operations occasionally included radiocobalt scavenging with nickel sulfide; consequently, nickel concentrations could be higher than the iron concentration (the expected molar ratio in ferrocyanide waste resulting from the In Farm scavenging process would be 1:1, Ni:Fe).

Comparison of the iron and nickel concentrations presented in Table 3-6 show fairly good matches for the quarter segments C47-1D and C49-1C; ratios of 0.9 and 1.3, respectively. However, the other samples exhibit significant differences with C49-1B having a gross excess of iron and C49-1D having a gross excess of nickel. Comparison of the quarter segments with the simulant suggests that the bottom quarter segment taken nearest the scavenged waste inlet was not mixed substantially during waste transfer operations. Comparison of the core 49 quarter segment (taken on the opposite side of the tank from the waste inlet) with the simulant indicates that the waste on the far side of the tank contains ferrocyanide waste that has been mixed with aluminum decladding waste.

Based on historical records, the waste in tank 241-C-112 is comprised of $61 \mathrm{~kL}$ of uranium recovery sludge, $250 \mathrm{~kL}$ of In Farm ferrocyanide sludge, $4 \mathrm{~kL}$ of an unknown waste, $80 \mathrm{~kL}$ of cladding waste, and a small amount of strontium semiworks waste. Occasionally, radiostrontium scavenging with calcium phosphate and radiocobalt scavenging with nickel sulfide occurred. Cores 35 and 36 were taken four to five meters away from the scavenging waste inlet, while core 34 was taken on the opposite side of the tank.

Comparison of the iron and nickel concentrations found in the simulant with those found in the waste samples indicates that the ferrocyanide waste has been mixed with other waste types. In each case the iron and nickel concentrations are less than would be predicted by the flowsheet simulants. However, the waste in subsegment C34-2B is near the expected concentrations. The C34-2C and C34-2D samples have nickel:iron mole ratios near that expected for ferrocyanide waste.

- Planned Work For Subsequent Months. Aging experiments will continue using the In Farm flowsheet simulant. Analyses of solids remaining after hydrolysis will be performed and all aging tests will be completed this fiscal year.

Cyanide speciation studies, using ion chromatography (IC) methods and solution IR methods, will be completed to validate the techniques and procedures that can be routinely applied to samples in the analytical laboratories at PNL and Westinghouse Hanford Company. The methods will be transferred to these laboratories for use. Cesium uptake experiments with simulated ferrocyanide wastes will be completed in July 1995. 
- Problem Areas and Actions Taken. All laboratory work was halted within radioactive control areas in the 325 Building in April 1994. Restart plans for the building were approved by DOE in December 1994, and work resumed in January 1995. The cyanide speciation and cesium uptake tasks resumed in late January 1995 and the milestone dates were adjusted accordingly.

- Milestone Status.

- January 31, 1995. PNL issues the final report, cleared for public release, on microconvection modeling and the effects projected to have occurred in the tank waste from this phenomenon during years of storage. A report was issued in November 1994 (McGrail 1994) to complete this milestone.

- July 31, 1995. PNL issues the final report, cleared for public release, on solution IR and IC cyanoferrate speciation activities and application for routine measurements in the analytical laboratories. This milestone date was slipped from September 1994 because of the 325 Building shutdown. This milestone is on schedule for completion July 31.

- July 31, 1995. PNL issues the final report, cleared for public release, on cesium uptake capacity of ferrocyanide. This milestone date was slipped from September 1994 because of the 325 Building shutdown. This milestone is on schedule for completion July 31 .

- September 29, 1995. PNL issues the final report integrating all Ferrocyanide Safety Program hydrolysis and radiolysis aging activities.

- September 29, 1995. PNL issues the final report, available to the public, on the solubility of sodium-cesium nickel ferrocyanide compounds under waste tank conditions. This milestone has been deleted and notification of this change is hereby provided in accordance with Section 3.7 of the program plan (DOE 1994b).

- September 29, 1995. PNL issues the final report, available to the public, on studies comparing chemical and physical parameters of ferrocyanide waste simulants with actual tank waste samples.

\subsubsection{Preparation and Characterization of Ferrocyanide Simulants}

Pure sodium nickel ferrocyanide is being prepared and analyzed to determine its chemical reaction properties with stoichiometric mixtures of sodium nitrate/nitrite as a function of water content. These tests are being conducted by FAI to clearly define the margin of safety between the theoretical and experimental propagation limits for ferrocyanide. These tests are run in the FAI reactive systems screening tool. These tests and previous tests with simulants--along with analyses of actual tank waste samples, waste tank monitoring, and 
waste modeling--provide information to characterize with a great deal of assurance safety concerns relating to the sludge in the ferrocyanide tanks.

- Progress During Reporting Period. A large batch (about 300 grams) of single-phase $\mathrm{Na}_{2} \mathrm{NiFe}(\mathrm{CN})_{6}$ is being prepared at Westinghouse Hanford Company to provide material for propagation tests at FAI. The chemical ingredients were received this quarter and production is anticipated to begin early next quarter.

- Planned Work for Subsequent Months. About 300 grams of single-phase $\mathrm{Na}_{2} \mathrm{NiFe}(\mathrm{CN})_{6}$ will be prepared and shipped to FAI. FAI will conduct propagation geometry tests using stoichiometric mixtures of sodium nickel ferrocyanide and sodium nitrate/nitrite with varying amounts of water.

- Milestone Status.

- July 31, 1995. Westinghouse Hanford Company releases a report, approved for public release, documenting the development and confirmation by testing of the contact temperature ignition criterion model.

- September 30, 1995. Westinghouse Hanford Company completes the ferrocyanide calorimetry and propagation test program at FAI as specified by Westinghouse Hanford Company, and prepares reports, available for public release, that support final resolution of the Ferrocyanide Safety Issue.

\subsection{EMERGENCY RESPONSE PLANNING}

"The Board had recommended 'that an action plan be developed for the measures to be taken to neutralize the conditions that may be signaled by alarms.' Two types of measures are implied: actions to respond to unexpected degradation of a tank or its contents, and actions to be taken if an explosion were to occur. Your implementation plan stated that 'the current contingency plans ... will be reviewed and revised if needed.' We do not consider that this proposed implementation of the Board's recommendation is adequately responsive. It is recommended that a written action plan founded on demonstrated principles be prepared as soon as possible, that would respond to indications of onset of abnormal temperatures or other unusual conditions in a ferrocyanide-bearing tank, to counter any perceived growth in hazard. A separate emergency plan should be formulated and instituted, covering measures that would be taken in event of an explosion or other event leading to an airborne release of radioactive material from the tanks, and that would protect personnel both on and off the Hanford Site. The Board believes that even though it is considered that the probability is small that such an event will occur, prudence dictates that steps be taken at this time to prepare the means to mitigate the unacceptable results that could ensue." 
The original Action Plan for Response to Abnormal Conditions in Hanford Radioactive Waste Tanks Containing Ferrocyanide (Cash and Thurman 1991) was prepared in response to DNFSB Recommendation 90-7.6. The plan describes the steps to be taken if a temperature increase trend above the tank temperature baseline is measured in any of the ferrocyanide tanks. The document was revised to include the monitoring criteria and responses for abnormal levels of flammable and toxic gases, as well as the reporting requirements, if established criteria are exceeded. The second revision of the plan was released in June 1994 (Fowler 1994).

The Tank Farm Stabilization Plan For Emergency Response (WHC 1991) was issued in March 1991. If a radioactive release from a ferrocyanide tank were to occur, it would be detected by one or more radiation monitoring systems. Significant airborne or ground surface releases that spread beyond the immediate tank or tank farm would be detected by the tank farm area radiation detectors. These monitoring systems are on all tank farms. An emergency involving an underground radioactive waste storage tank is a unique event with potentially serious consequences both onsite and offsite. The Stabilization Plan provides quick, preplanned actions that can be used to stabilize an emergency event at an underground radioactive waste storage tank.

All actions with respect to emergency planning, emergency event recognition, protective action recommendations, and emergency response procedures have been completed. Further revisions and occasional validation exercises will be accomplished as part of the normal Westinghouse Hanford Company and DOE emergency planning efforts. No further reporting on these issues is planned, and this part of DNFSB Recommendation 90-7.6 is considered complete and closed.

DOE considers this recommendation to be closed with the provisos that the abnormal conditions response plan and emergency plans are reviewed on a periodic basis and revised and updated as required to incorporate any additional controls determined appropriate by the ongoing Waste Tank Safety Program investigations (e.g., the Action Plan for Response to Abnormal Conditions in Hanford Site Radioactive Waste Tanks Containing Ferrocyanide was updated and released in June 1994 [Fowler 1994]); and that validation exercises for various waste tank accident scenarios are conducted periodically (exercises for the tank farms are conducted every two years).

- Progress During Reporting Period. As noted in previous reports, all of the planned milestones for this task were completed.

- Planned Work For Subsequent Months. None planned.

- Problem Areas and Action Taken. None.

- Milestone Status. All milestones have been completed. 
This page intentionally left blank. 


\subsection{IMPLEMENTATION OF THE WYDEN AMENDMENT}

The Wyden Amendment (Public Law 101-510, Section 3137, 1990) requires that:

"...the Secretary of Energy shall identify which single-shelled or double-shelled high-level nuclear waste tanks at the Hanford Nuclear Reservation, Richland, Washington, may have a serious potential for release of high-level waste due to uncontrolled increases of temperature or pressure. After completing such identification, the Secretary shall determine whether continuous monitoring is being carried out to detect a release or excessive temperature or pressure at each tank so identified. If such monitoring is not being carried out, as soon as practicable the Secretary shall install such monitoring, but only if a type of monitoring that does not itself increase the danger of a release can be installed."

\subsection{THE WATCH LIST}

In March 1989, using process knowledge, process records, transfer records, and log books, Westinghouse Hanford Company (Nguyen 1989) identified 22 Hanford Site tanks as potentially containing $1,000 \mathrm{~g}$-moles $(211 \mathrm{~kg}$ [465 lb]) or more of ferrocyanide [as the $\mathrm{Fe}(\mathrm{CN})_{6}^{4}$ anion]. To avert possible injury to personnel and damage to the facility or environment, strict controls were identified for these and other Safety Issue tanks. These controls were described in the document, Operating Specifications for Watch List Tanks (WHC 1990). Tanks identified via this document (see WHC [1994] for latest revision) have been commonly referred to as Watch List tanks. Two additional ferrocyanide tanks were identified in January 1991 (Borsheim and Cash 1991), increasing the number of ferrocyanide tanks to 24 .

In November 1990, the Wyden Amendment (Public Law 101-510, Section 3137, 1990) was enacted. This law required the identification of Hanford Site tanks that may have a serious potential for release of high-level waste. In February 1991 (Harmon 1991), the 24 ferrocyanide tanks were among the tanks identified, and were included in the subsequent July 1991 report to Congress (Watkins 1991) that responded to the Wyden Amendment. However, re-examination of the historical records (Borsheim and Simpson 1991) indicated that six of the 24 tanks did not contain the requisite $1,000 \mathrm{~g}$-moles of ferrocyanide. Therefore, these six tanks should not have been included on the Watch List nor been identified in the response to the Wyden Amendment. The six tanks were subsequently removed from the Watch List (Anttonen 1993, Sheridan 1994b) (Note: these tanks do not contain greater than $8 \mathrm{wt} \% \mathrm{Na}_{2} \mathrm{NiFe}(\mathrm{CN})_{6}$ and should not be on the Watch List for this reason also).

As part of the overall safety screening module being conducted by Westinghouse Hanford Company Tank Waste Remediation System, all of the Hanford Site SSTs will be core sampled and characterized (Note: the $115 \mathrm{cal} / \mathrm{g}$ of dry fuel criterion established for 
ferrocyanide tanks is now the adopted limit used for safety screening [Babad et al. 1995]). Eighteen ferrocyanide tanks are currently on the Watch List, and no more tanks are expected to be added to the Ferrocyanide Watch List.

Work conducted since 1991 on ferrocyanide reactions has resulted in a change of the criterion used for placing ferrocyanide tanks on the Watch List. The 1,000 g-mole inventory criterion has now been replaced with a fuel concentration criterion of $115 \mathrm{cal} / \mathrm{g}$ of dry sample (this is an energy equivalent to a concentration of $8 \mathrm{wt} \% \mathrm{Na}_{2} \mathrm{NiFe}(\mathrm{CN})_{6}$ in the waste). This fuel concentration criterion more accurately reflects the risk associated with ferrocyanide tanks. Ferrocyanide tanks with concentrations less than an energy equivalent of $8 \mathrm{wt} \%$ $\mathrm{Na}_{2} \mathrm{NiFe}(\mathrm{CN})_{6}$ cannot support a propagating reaction, and are categorized as safe. Detailed rationale for the $115 \mathrm{cal} / \mathrm{g}$ of dry fuel concentration criterion is presented in Postma et al. (1994a).

Core sampling and characterization efforts will determine the ferrocyanide concentration for those tanks that bound aging (see Sections 2.2 and 3.4). After adequate characterization, if these tanks contain concentrations less than $8 \mathrm{wt} \% \mathrm{Na}_{2} \mathrm{NiFe}(\mathrm{CN})_{6}$ (i.e., the fuel value of the maximum concentration is less than $115 \mathrm{cal} / \mathrm{g}$ ), then a request will be made by Westinghouse Hanford Company for DOE concurrence to remove all of the ferrocyanide tanks from the Watch List.

Some sample bias and analytical error is unavoidable; therefore, confidence intervals have been established to specify when it is appropriate to conclude that a ferrocyanide tank contains concentrations less than an energy equivalent of $8 \mathrm{wt} \% \mathrm{Na}_{2} \mathrm{NiFe}(\mathrm{CN})_{6} . \mathrm{An}$ $80 \%$ confidence interval was chosen for tanks with a fuel concentration of $8 \mathrm{wt} \%$ $\mathrm{Na}_{2} \mathrm{NiFe}(\mathrm{CN})_{6}$. That is, if five ferrocyanide tanks contain exactly an energy equivalent of $8 \mathrm{wt} \% \mathrm{Na}_{2} \mathrm{NiFe}(\mathrm{CN})_{6}$, statistically, four tanks would remain on the Watch List and one tank would be removed. The possibility of removing a ferrocyanide tank from the Watch List decreases substantially as the fuel concentration increases. The confidence intervals increase to $95 \%$ and $99 \%$ at $\mathrm{Na}_{2} \mathrm{NiFe}(\mathrm{CN})_{6}$ concentrations of $12 \%$ and $15 \mathrm{wt} \%$, respectively. Detailed discussions on how sample bias and analytical error are factored into determining the actual fuel concentrations in a ferrocyanide tank are given in the Ferrocyanide Data Quality Objectives document (Meacham et al. 1994a).

- Planned Work To Complete Program. An increased understanding of ferrocyanide aging indicates that little ferrocyanide remains, and the assumption that it is necessary to core sample all ferrocyanide tanks may not be valid. By characterizing the waste in only those tanks that bound aging (i.e., tanks with conditions least conducive to aging), the Ferrocyanide Safety Issue could be resolved much earlier and at a substantially reduced cost. As more core sample data become available, the need to sample all the ferrocyanide tanks will be reexamined. 
- Milestones.

- January 31, 1996. Westinghouse Hanford Company issues documentation supporting resolution of the Ferrocyanide Safety Issue for the four C Farm tanks, and recommends resolution of the Ferrocyanide Safety Issue for C Farm tanks. All four C Farm tanks have been sampled and data interpretation reports are now in preparation for tanks 241-C-108 and -C-111. The reports for tanks 241-C-109 and -C-112 were issued earlier (Simpson et al. 1993a, 1993b).

- July 31, 1996. Westinghouse Hanford Company receives DOE approval to resolve the Ferrocyanide Safety Issue for C Farm tanks.

- March 31, 1997. Westinghouse Hanford Company prepares documentation to support resolution of the Ferrocyanide Safety Issue for the remaining 14 tanks, and recommends Ferrocyanide Safety Issue resolution for all remaining tanks.

- September 30, 1997. Westinghouse Hanford Company receives DOE approval to resolve the Ferrocyanide Safety Issue. This completes the Ferrocyanide Safety Program.

\subsection{TEMPERATURE MONITORING}

The installation of temperature monitoring capabilities is discussed in Sections 3.1.2.1 and 3.2.2. Installation of instrument trees and continuous temperature monitoring are considered prudent waste management practices (monitoring temperatures helps follow the initiators' side of the fire triangle). Therefore, new instrument trees will be installed in ferrocyanide tanks, even though the ferrocyanide waste has aged and little fuel value remains.

- Planned Work To Complete Program. Instrument trees will be inserted in the remaining ferrocyanide tanks (currently there are five ferrocyanide tanks that still require installation of trees). This will provide two operating instrument trees in all but three ferrocyanide tanks (see Section 3.1.2.1 for discussion on instrument trees). All instrument trees will be connected to TMACS for continuous monitoring. Completion of this task is anticipated by the end of FY 1995.

\section{- Milestones}

- September 30, 1995. Westinghouse Hanford Company completes installation of instrument trees in all ferrocyanide tanks and connects trees to TMACS. Existing temperature-sensing elements in tanks $241-\mathrm{BY}-105$ and -106 will be replaced, if necessary. This milestone completes Tri-Party Agreement Milestone M-40-02. 


\subsection{PRESSURE MONITORING}

The ferrocyanide tanks were initially identified as having "a serious potential for release" and were placed on the Watch List because insufficient data were available on the probability for ferrocyanide-nitrate/nitrite reactions. Pressure monitoring is not presently installed on the ferrocyanide tanks. It would take several years to install pressure monitoring instrumentation because of the capital project time cycle. Ferrocyanide waste has probably degraded (aged) significantly, and all of the tanks may now contain less than the $8 \mathrm{wt} \% \mathrm{Na}_{2} \mathrm{NiFe}(\mathrm{CN})_{6}$ fuel concentration specified for the safe category (see also Postma et al. 1994a). This eliminates the need for continuous pressure monitoring for offgases from a ferrocyanide reaction.

The rationale for not installing pressure monitors in ferrocyanide tanks was prepared and submitted to DOE in July 1994 (Payne 1994b). Low gas generation rates (Fowler and Graves 1994) and the low potential for exothermic ferrocyanide reactions (Postma et al. 1994a) indicated that continuous pressure monitoring is not warranted.

- Planned Work For Subsequent Months. No additional work is planned in this area, because DOE has concurred that pressure monitoring is not required as stated in the revised Ferrocyanide Safety Issue Program Plan (O'Leary 1994).

- Milestones. None. 


\subsection{PROGRAM SCHEDULES AND MILESTONES}

Schedules (Figure 5-1) are presented in this section. The schedules review milestones for FY 1994 through the expected end of the program in FY 1997. The sequence and anticipated completion dates of the major milestones leading to resolution of the Ferrocyanide Safety Issue are presented. Closure of DNFSB recommendations are indicated on the schedule as diamonds, and completion of interim milestones are indicated as triangles. The schedules are statused through June 30, 1995. 
Figure 5-1. Ferrocyanide Waste Tank Safety Schedule. (Sheet 1 of 2)

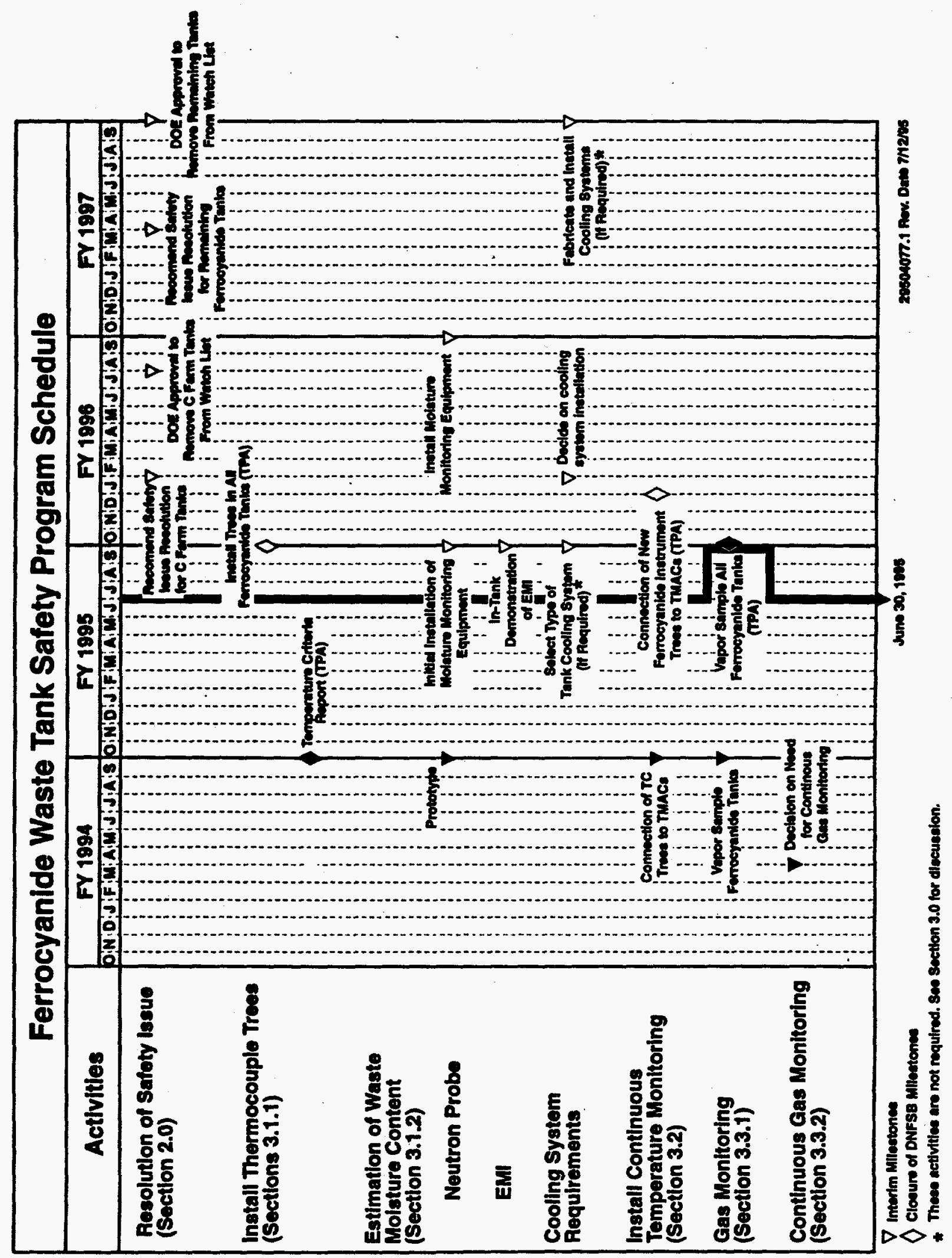


Figure 5-1. Ferrocyanide Waste Tank Safety Schedule. (Sheet 2 of 2)

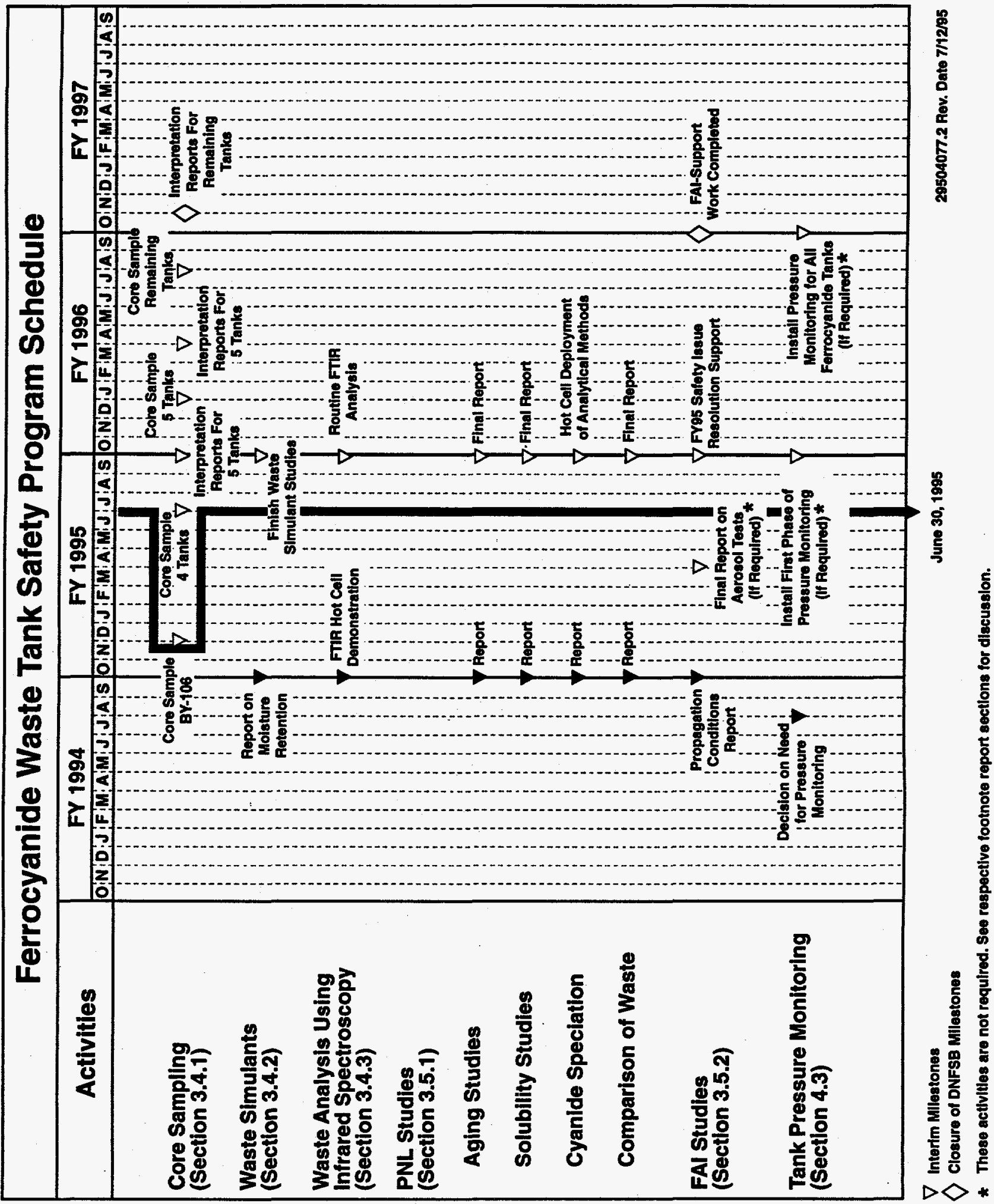


This page intentionally left blank. 


\subsection{REFERENCES}

Anttonen, J. H., 1993, Resolution of Unreviewed Safety Question (USQ) for Four Ferrocyanide Tanks, (letter 9304645B/93-CAB-223 to T. M. Anderson, President, Westinghouse Hanford Company, July 9), U.S. Department of Energy, Richland Operations Office, Richland, Washington.

Babad, H., J. W. Hunt, and K. S. Redus, 1995, Tank Safety Screening Data Quality Objective, WHC-SD-WM-SP-004, Rev. 1, Westinghouse Hanford Company, Richland, Washington.

Bell, K. E., 1995, 90-Day Safety Screen Results for Tank 241-BY-106, Rotary Mode, Cores 64 and 65, WHC-SD-WM-DP-103, Rev. 0A, Westinghouse Hanford Company, Richland, Washington.

Borsheim, G. L., and R. J. Cash, 1991, Unusual Occurrence - Addition of Two Tanks to List of Unreviewed Safety Question Tanks Containing Ferrocyanide, WHC-91-0096-TFARM, February 13, Westinghouse Hanford Company, Richland, Washington.

Borsheim, G. L., and B. C. Simpson, 1991, An Assessment of the Inventories of Ferrocyanide Watch List Tanks, WHC-SD-WM-EP-133, Rev. 0, Westinghouse Hanford Company, Richland, Washington.

Bussell, J. H., 1992, Engineering Evaluation of Thermocouples in Ferrocyanide Watch List Tanks, WHC-SD-WM-ER-134, Rev. 0 and Rev. OA, Westinghouse Hanford Company, Richland, Washington.

Cady, H. H., 1993,.Evaluation of Ferrocyanide/Nitrate Explosive Hazard, LA-12589-MS, Los Alamos National Laboratory, Los Alamos, New Mexico.

Cash, R. J., 1991, Implementation Plan for the Defense Nuclear Facilities Safety Board Recommendation 90-7, WHC-EP-0415, Rev. 0, Westinghouse Hanford Company, Richland, Washington.

Cash, R. J., and J. M. Thurman, 1991, Action Plan for Response to Abnormal Conditions in Hanford Site Radioactive Waste Tanks Containing Ferrocyanide, EP-0407, Rev. 0, Westinghouse Hanford Company, Richland, Washington.

R. J. Cash, J. E. Meacham, and G. T. Dukelow, 1995, Quarterly Report on the Ferrocyanide Safety Program for the Period Ending March 31, 1995, WHC-EP-0474-16, Westinghouse Hanford Company, Richland, Washington.

Claybrook, S. W., and S. A. Wood, 1994, Organic Evaporation in Waste Tank C-103, WHC-SD-WM-ER-344, Rev. 0, Westinghouse Hanford Company, Richland, Washington. 
Crowe, R. D., M. Kummerer, and A. K. Postma, 1993, Estimation of Heat Load in Waste Tanks Using Average Vapor Space Temperatures, WHC-EP-0709, Westinghouse Hanford Company, Richland, Washington.

Deaton, D. E., 1990, Unusual Occurrence - Unreviewed Safety Questions Regarding Tanks Containing Ferrocyanide, WHC-90-B003-R1 (Update 10-22-90), Westinghouse Hanford Company, Richland, Washington.

Dickinson, D. R., J. M. McLaren, G. L. Borsheim, and M. D. Crippen, 1993, Ferrocyanide Safety Program: Credibility of Drying Out Ferrocyanide Tank Waste by Hot Spots, WHC-EP-0648, Rev. 0, Westinghouse Hanford Company, Richland, Washington.

DOE, 1987, Final Environmental Impact Statement, Disposal of Hanford Defense High-Level, Transuranic and Tank Waste, Hanford Site, Richland, Washington, DOE/EIS-0113, Vol. 1 through 5, U.S. Department of Energy, Washington, D.C.

DOE, 1994a, Recommendation 93-5 Implementation Plan, DOE/RL 94-0001, U.S. Department of Energy, Richland Operations Office, Richland, Washington.

DOE, 1994b, Program Plan for Resolution of the Ferrocyanide Waste Tank Safety Issue at the Hanford Site, DOE/RL-94-110, Rev. 1, U.S. Department of Energy, Richland Operations Office, Richland, Washington.

Ecology, EPA, and DOE, 1994, Hanford Federal Facility Agreement and Consent Order, as amended, Washington State Department of Ecology, U.S. Environmental Protection Agency, and U.S. Department of Energy, Olympia, Washington.

Epstein, M., H. K. Fauske, M. D. Crippen, D. R. Dickinson, J. D. McCormack, R. J. Cash, J. E. Meacham, and C. S. Simmons, 1994, Ferrocyanide Safety Program: An Assessment of the Possibility of Ferrocyanide Sludge Dryout, WHC-EP-0816, Westinghouse Hanford Company, Richland, Washington.

FR, 1990, "Implementation Plan for Recommendation 90-3 at the Department of Energy's Hanford Site, Washington," Federal Register, Defense Nuclear Facilities Safety Board Recommendation 90-7, Vol. 55, No. 202, pp. 42243 - 42244.

Fowler, K. D., 1994, Action Plan for Response to Abnormal Conditions in Hanford Site Radioactive Waste Tanks Containing Ferrocyanide, WHC-EP-0407, Rev. 2, Westinghouse Hanford Company, Richland, Washington.

Fowler, K. D., and R. D. Graves, 1994, Decision Analysis for Continuous Cover Gas Monitoring of Ferrocyanide Watch List Tanks, WHC-EP-0743, Westinghouse Hanford Company, Richland, Washington. 
Gerton, R. E., 1994, Environmental Assessment (EA) and Finding of No Significant Impact (FONSI) for the Waste Tank Safety Program at the Hanford Site, (DOE/EA-0915), (letter 9402034B/94-SST-053 to President, Westinghouse Hanford Company, March 8), U.S. Department of Energy, Richland, Washington.

Grigsby, J. M., D. B. Bechtold, G. L. Borsheim, M. D. Crippen, D. R. Dickinson, G. L. Fox, D. W. Jeppson, M. Kummerer, J. M. McLaren, J. D. McCormack, A. Padilla, B. C. Simpson, and D. D. Stepnewski, 1992, Ferrocyanide Waste Tank Hazard Assessment--Interim Report, WHC-SD-WM-RPT-032, Rev. 1, Westinghouse Hanford Company, Richland, Washington.

Harmon, H. D., 1991, Safety Measures for Waste Tanks at Hanford Site, Richland, Washington, (letter 9059124.1 to R. E. Gerton, DOE-RL, February 8), Westinghouse Hanford Company, Richland, Washington.

Hertelendy, N. A., 1993, Final Test Report - Ultra High Pressure Water as a Tool to Bore, Drill, Cut or Penetrate Hard Saltcake-Like Nuclear Waste, WHC-SD-WM-RPT-132, Rev. 0, Westinghouse Hanford Company, Richland, Washington.

Kress, T., K. Bandyopadhyay, P. d'Entremont, S. Slezak, and M. Reich, 1990, Risk of a Ferrocyanide Explosion in the Hanford Waste Tank Farm, (memorandum to John Tseng, DOE-HQ, September 20), Ad Hoc Task Force formed by U.S. Department of Energy to evaluate the ferrocyanide safety concerns at the Hanford Site, Oak Ridge National Laboratory, Oak Ridge, Tennessee.

McGrail, B. P., 1994, Ferrocyanide Tank Safety Project: Computational Analysis of Coupled Fluid, Heat, and Mass Transport in Ferrocyanide Single-Shell Tanks - FY 1994 Interim Report, PNL-10163, Pacific Northwest Laboratory, Richland, Washington.

McLaren, J. M., 1993, Ferrocyanide Safety Program: Updated Thermal Analysis Model for Ferrocyanide Tanks with Application to Tank 241-BY-104, WHC-EP-0669, Westinghouse Hanford Company, Richland Washington.

McLaren, J. M., 1994a, Ferrocyanide Safety Program: Thermal Analysis of Ferrocyanide Tanks, Group I, WHC-EP-0729, Westinghouse Hanford Company, Richland, Washington.

McLaren, J. M. 1994b, Ferrocyanide Safety Program: Thermal Analysis of Ferrocyanide Watch List Tanks, Group II, WHC-EP-0794, Westinghouse Hanford Company, Richland, Washington.

Meacham, J. E., H. Babad, and H. Toffer, 1993, Moisture Monitoring of Ferrocyanide Tanks: An Evaluation of Methods and Tools, WHC-EP-0658, Westinghouse Hanford Company, Richland, Washington. 
Meacham, J. E., R. J. Cash, B. A. Pulsipher, and G. Chen, 1995a, Data Requirements for the Ferrocyanide Safety Issue Developed Through the Data Quality Objectives Process, WHC-SD-WM-DQO-007, Rev. 1, Westinghouse Hanford Company, Richland, Washington.

Meacham, J. E., H. Babad, R. J. Cash, G. T. Dukelow, S. J. Eberlein, D. W. Hamilton, J. L. Huckaby, G. D. Johnson, J. W. Osborne, M. A. Payne, D. J. Sherwood, and D. A. Turner, 1995b, Approach for Tank Safety Characterization of Hanford Site Waste, WHC-EP-0843, Westinghouse Hanford Company, Richland, Washington.

Meacham, J. E., R. J. Cash, and G. T. Dukelow, 1995c, Quarterly Report on the Ferrocyanide Safety Program for the Period Ending December 31, 1994, WHC-EP-0474-15, Westinghouse Hanford Company, Richland, Washington.

Neskas, J. W., and G. L. Borsheim, 1993, Data Interpretation Report on Tank 241-BY-104 Auger Samples, WHC-SD-WM-RPT-068, Rev. 0, Westinghouse Hanford Company, Richland, Washington.

NIOSH, 1995, NIOSH Pocket Guide to Chemical Hazards, U. S. Department of Health and Human Resources, National Institute for Occupational Safety and Health, Cincinnati, Ohio.

Nguyen, D. M., 1989, Data Analysis of Conditions in Single-Shell Tanks Suspected of Containing Ferrocyanide, (internal memorandum 13314-89-025 to N. W. Kirch, March 2), Westinghouse Hanford Company, Richland, Washington.

O'Leary, H. R., 1994, /Transmittal of "Program Plan for Evaluation of the Ferrocyanide Waste Tank Safety issue at the Hanford Site, "DOE/RL-94-110], (letter to J. T. Conway, Chairman, Defense Nuclear Facilities Safety Board, December 2), U.S. Department of Energy, Washington, D.C.

Payne, M. A., 1994a, Ferrocyanide Safety Program: Transmittal of General Accounting Office Closeout Report, (letter 9454280 to R. E. Gerton, DOE-RL, June 16), Westinghouse Hanford Company, Richland, Washington.

Payne, M. A., 1994b, Ferrocyanide Safety Program: Continuous Pressure Monitoring in Ferrocyanide Watch List Tanks, (letter 9455175 to R. E. Gerton, DOE-RL, July 29), Westinghouse Hanford Company, Richland, Washington.

Peach, J. D., 1990, Consequences of Explosion of Hanford's Single-Shell Tanks are Understated, (letter B-241479 to M. Synar, Chairman, Environment, Energy, and Natural Resources Subcommittee, Committee on Government Operations, House of Representatives, October 10), GAO/RCED-91-34, U.S. General Accounting Office, Washington, D.C. 
Postma, A. K., J. E. Meacham, G. S. Barney, G. L. Borsheim, R. J. Cash, M. D. Crippen, D. R. Dickinson, J. M. Grigsby, D. W. Jeppson, M. Kummerer, J. M. McLaren, C. S. Simmons, and B. C. Simpson, 1994a, Ferrocyanide Safety Program: Safety Criteria for Ferrocyanide Watch List Tanks, WHC-EP-0691, Westinghouse Hanford Company, Richland, Washington.

Postma, A. K., D. B. Bechtold, G. L. Borsheim, J. M. Grigsby, R. L. Guthrie, M. Kummerer, M. G. Plys, and D. A. Turner, 1994b, Safety Analysis of Exothermic Reaction Hazards Associated with the Organic Liquid Layer in Tank 241-C-103, WHC-SD-WM-SARR-001, Rev. 0, Westinghouse Hanford Company, Richland, Washington.

Public Law 101-510, Section 3137, 1990, Safety Measures for Waste Tanks at Hanford Nuclear Reservation, U.S. Congress, Washington, D.C. [Also referred to as the Wyden Amendment]

Rai, D., A. R. Felmy, S. C. Smith, and J. L. Ryan, 1994, Ferrocyanide Safety Project: Interim Report FY 1994 - Solubility of Ferrocyanide Compounds, PNL-10150, Pacific Northwest Laboratory, Richland, Washington.

Reich, F. R., R. E. Johnson, B. L. Philipp, J. B. Duncan, and G. L. Schutzenhofer, 1994, Summary of Fiscal Year 1994 Near-Infrared Spectroscopy Moisture Sensing Activities, WHC-EP-0839, Westinghouse Hanford Company, Richland, Washington.

Rice, A. D., 1995, 60-Day Safety Screen Results and Final Report for Tank 241-C-111, Auger Samples 95-AUG-002, 95-AUG-003, 95-AUG-016, and 95-AUG-017, WHC-SD-WM-DP-114, Rev. 0, Westinghouse Hanford Company, Richland, Washington.

Sheridan, T. R., 1994a, Closure of the Ferrocyanide Unreviewed Safety Question, (letter 9401180/94-SST-052 to A. L. Trego, President, Westinghouse Hanford Company, March 4), U.S. Department of Energy, Richland Operations Office, Richland, Washington.

Sheridan, T. R., 1994b, Approval to Remove Two Ferrocyanide Tanks, 241-BX-102 and 241-BX-106, from the Watch List, (letter 9406684/94-SST-205 to A. L. Trego, President, Westinghouse Hanford Company, November 17), U.S. Department of Energy, Richland Operations Office, Richland, Washington.

Simpson, B. C., G. L. Borsheim, and L. Jensen, 1993a, Tank Characterization Report: Tank 241-C-109, WHC-EP-0688, Westinghouse Hanford Company, Richland, Washington.

Simpson, B. C., G. L. Borsheim, and L. Jensen, 1993b, Tank Characterization Data Report: Tank 241-C-112, WHC-EP-0640, Rev. 1, Westinghouse Hanford Company, Richland, Washington. 
Sloat, R. J., 1954, TBP Plant Nickel Ferrocyanide Scavenging Flowsheet, HW-30399, General Electric Company, Richland, Washington.

Sloat, R. J. 1955, In-Farm Scavenging Operating Procedure and Control Data, HW-38955, General electric Company, Richland, Washington.

Smith, D. A., 1986, Single-Shell Tank Isolation Safety Analysis Report, SD-WM-SAR-006, Rev. 2, Westinghouse Hanford Company, Richland, Washington.

Wagoner, J. D., 1993, Approval of Hanford Site Tank Farm Facilities Interim Safety Basis, (letter 93-TOB-209 to T. M. Anderson, President, Westinghouse Hanford Company, November 18), U.S. Department of Energy, Richland Operations Office, Richland, Washington.

Watkins, J. D., 1991, Report to United States Congress on Waste Tank Safety Issues at the Hanford Site, (letter to D. Quayle, President of the Senate, July 16), U.S. Department of Energy, Washington, D.C.

Watson, W. T., 1993, Proof of Principle Report for In-Tank Moisture Monitoring Using an Active Neutron Probe, WHC-EP-0695, Westinghouse Hanford Company, Richland, Washington.

WHC, 1990, Operating Specifications for Watch List Tanks, OSD-T-151-00030, Rev. 0, Westinghouse Hanford Company, Richland, Washington.

WHC, 1991, Tank Farm Stabilization Plan for Emergency Response, WHC-SD-PRP-TI-001, Rev. 0, Westinghouse Hanford Company, Richland, Washington.

WHC, 1994, Operating Specifications for Watch List Tanks, OSD-T-151-00030, Rev. B-2, Westinghouse Hanford Company, Richland, Washington.

Wodrich, D. D., G. S. Barney, G. L. Borsheim, D. L. Becker, W. C. Carlos, M. J. Klem, R. E. Van der Cook, and J. L. Ryan, 1992, Summary of Single-Shell Waste Tank Stability, WHC-EP-0347, Supplement, Westinghouse Hanford Company, Richland, Washington.

Wood, S. A., 1992, Gas Space Analysis For Tank C-109, WHC-SD-WM-ER-183, Rev. 0, Westinghouse Hanford Company, Richland, Washington. 
APPENDIX A

FERROCYANIDE TANK INFORMATION SUMMARY 
This page intentionally left blank. 
Table A-1. Summary of Contents and Status of Ferrocyanide Tanks.*

\begin{tabular}{|c|c|c|c|c|c|c|}
\hline Tank & $\begin{array}{c}\text { Total waste } \\
\text { volume } \\
(1,000 \mathrm{~L})\end{array}$ & $\begin{array}{c}\mathrm{FeCN}^{\mathrm{b}} \\
(1,000 \text { g-mole })\end{array}$ & $\begin{array}{l}\text { Heat load } \\
(\mathrm{kW})^{\mathrm{c}}\end{array}$ & $\begin{array}{l}\text { Maximum } \\
\text { temp. } \\
\left({ }^{\circ} \mathrm{C}\right)\left({ }^{\circ} \mathrm{F}\right)\end{array}$ & Riser No. & $\begin{array}{l}\text { Status of } \\
\operatorname{tanks}^{d}\end{array}$ \\
\hline BY-103 & 1510 & 66 & 1.6 & $27 \quad 81$ & 1 & NS; AL \\
\hline BY-104 & 1540 & 83 & 2.6 & $\begin{array}{ll}45^{e} & 112 \\
52 & 126\end{array}$ & $\begin{array}{c}1 \\
10 \mathrm{~B}\end{array}$ & IS; Sound \\
\hline BY -105 & 1900 & 36 & 2.6 & $\begin{array}{ll}45 & 113 \\
49 & 119\end{array}$ & $\begin{array}{c}1 \\
10 \mathrm{C}\end{array}$ & NS; AL \\
\hline BY-106 & 2430 & 70 & 3.0 & $\begin{array}{ll}53 & 128\end{array}$ & 1 & NS; AL \\
\hline BY-107 & 1010 & 42 & 2.6 & $\begin{array}{cc}37 & 98 \\
--\mathrm{f} & --\end{array}$ & $\begin{array}{l}1 \\
5\end{array}$ & IS; AL \\
\hline BY-108 & 863 & 58 & 2.7 & $\begin{array}{ll}42 & 108\end{array}$ & 8 & IS; AL \\
\hline BY-110 & 1510 & 71 & 2.0 & $\begin{array}{ll}48 & 118 \\
42^{\circ} & 107\end{array}$ & $\begin{array}{c}1 \\
10 \mathrm{~A}\end{array}$ & IS; Sound \\
\hline BY-111 & 1690 & 6 & 1.6 & $29^{e} \quad 84$ & 14 & IS; Sound \\
\hline BY-112 & 1100 & 2 & 1.8 & $32^{\circ} \quad 90$ & 2 & IS; Sound \\
\hline C-108 & 250 & 25 & 1.8 & $\begin{array}{ll}24^{\mathrm{e}} & 74 \\
23 & 73\end{array}$ & $\begin{array}{l}1 \\
5\end{array}$ & IS; Sound \\
\hline C-109 & 250 & $6.8^{8}$ & 2.1 & $\begin{array}{ll}26^{e} & 79 \\
26 & 78\end{array}$ & $\begin{array}{l}3 \\
8\end{array}$ & IS; Sound \\
\hline C-111 & 216 & 33 & 2.0 & $22 \quad 72$ & 5 & IS; AL \\
\hline C-112 & 394 & $11.5^{\mathrm{g}}$ & 2.2 & $\begin{array}{ll}27 & 80 \\
27^{\mathrm{e}} & 80\end{array}$ & $\begin{array}{l}1 \\
8\end{array}$ & IS; Sound \\
\hline $\mathrm{T}-107$ & 681 & 5 & 0.9 & $\begin{array}{ll}18 & 64 \\
20^{\mathrm{e}} & 68\end{array}$ & $\begin{array}{l}4 \\
5\end{array}$ & NS; AL \\
\hline TX-118 & 1310 & $<3$ & 1.4 & $\begin{array}{cc}-f & -- \\
25 & 77\end{array}$ & $\begin{array}{l}1 \\
3\end{array}$ & IS; Sound \\
\hline TY-101 & 447 & 23 & 0.9 & $18 \quad 65$ & 4 & IS; AL \\
\hline TY-103 & 613 & 28 & 1.2 & $20 \quad 69$ & 4 & IS; AL \\
\hline TY-104 & 174 & 12 & 0.9 & $\begin{array}{ll}17^{e} & 63 \\
18 & 64\end{array}$ & $\begin{array}{l}3 \\
4\end{array}$ & IS; AL \\
\hline
\end{tabular}


Table A-1 Notes:

- Reflects removal of four ferrocyanide tanks from Watch List in July 1993 and two additional tanks in October 1994. Tank information and temperature data as of June 1995.

b Inventories from Borsheim and Simpson (1991).

c Heat load values from Table 7-1 in Crowe et al. (1993).

d IS - Interim Stabilized Tank; NS - Not Stabilized; AL - Assumed Leaker Tank; Sound - Non-Leaking Tank.

- Readings from new instrument trees; tank 241-BY-105 already had two trees.

f Readings have not yet been taken on this new instrument tree.

- Calculated as ferrocyanide $\left[\mathrm{Fe}(\mathrm{CN})_{6}^{4}\right]$ based on the total cyanide values reported in Simpson et al. (1993a, 1993b). 
Table A-2. Ferrocyanide Tank Vapor Sampling Summary. (2 Sheets)

\begin{tabular}{|c|c|c|c|c|c|c|c|c|c|c|c|c|c|}
\hline Tank & $\begin{array}{c}\text { Date } \\
\text { Sampled } \\
\text { (Type)' }\end{array}$ & \begin{tabular}{|c|} 
Flamm. \\
(\% LEL) $^{b}$
\end{tabular} & $\begin{array}{c}\text { Organic } \\
\text { Vapor } \\
(\text { ppmv) }\end{array}$ & $\begin{array}{c}\mathrm{NH}_{3} \\
\left(\mathrm{ppmv}^{\mathrm{d}}\right)^{\mathrm{d}}\end{array}$ & $\begin{array}{c}\mathrm{NH}_{3} \\
(\text { ppmve }\end{array}$ & $\begin{array}{c}\begin{array}{c}\text { HCN } \\
(\text { ppmv) }\end{array} \\
\end{array}$ & $\begin{array}{l}\mathrm{NO}+\mathrm{NO}_{2} \\
(\mathrm{ppmv})^{\mathrm{d}}, \mathrm{s}\end{array}$ & $\begin{array}{l}\text { TNMOC } \\
\left(\mathrm{mg} / \mathrm{m}^{3}\right)^{f}\end{array}$ & $\begin{array}{c}\mathrm{H}_{2} \\
\left(\text { ppmv }^{2}\right.\end{array}$ & $\begin{array}{c}\mathrm{N}_{2} \mathrm{O} \\
(\mathrm{ppmv})^{8}\end{array}$ & $\frac{\mathrm{CO}}{\left(\text { (ppmv) }^{8}\right.}$ & $\frac{\mathrm{CO}_{2}}{(\mathrm{ppmv})^{2}}$ & $\begin{array}{c}\text { Water } \\
\text { Content } \\
\text { \% RH }\left({ }^{\circ} \mathrm{C}\right)^{\mathrm{h}}\end{array}$ \\
\hline BY-103 & $\begin{array}{l}05 / 05 / 94 \text { (2) } \\
11 / 01 / 94 \text { (3) }\end{array}$ & $<1$ & $\begin{array}{l}1.2 \\
--\end{array}$ & 25 & $\begin{array}{l}30.7 \\
26\end{array}$ & $\begin{array}{c}<0.005^{1} \\
--\end{array}$ & $\begin{array}{l}<0.3 \\
<0.2\end{array}$ & $\begin{array}{l}5.2 \\
--\end{array}$ & $\begin{array}{r}21.4 \\
<99\end{array}$ & $\begin{array}{l}49.2 \\
16.5\end{array}$ & $\begin{array}{l}<1 \\
<12\end{array}$ & 126 & $49\left(25 . \overline{5}^{\circ} \mathrm{C}\right)$ \\
\hline BY-104 & $\begin{array}{l}04 / 22 / 94 \text { (2) } \\
06 / 24 / 94 \text { (3) }\end{array}$ & $\begin{array}{r}<1 \\
--\end{array}$ & $\begin{array}{c}26 \\
--\end{array}$ & $\begin{array}{r}200 \\
-\end{array}$ & $\begin{array}{l}285 \\
248\end{array}$ & $\begin{array}{c}<0.005^{1} \\
-\end{array}$ & $\begin{array}{l}<0.3 \\
<0.4\end{array}$ & $\begin{array}{l}56 \\
61\end{array}$ & $\begin{array}{l}204 \\
295\end{array}$ & $\begin{array}{l}305 \\
201\end{array}$ & $\begin{array}{r}<1 \\
1\end{array}$ & $\overline{10.5}$ & $58\left(26^{\circ} \mathrm{C}\right)$ \\
\hline BY-105 & $\begin{array}{l}05 / 09 / 94(2) \\
07 / 07 / 94 \text { (3) }\end{array}$ & $\begin{array}{l}<1 \\
.-\end{array}$ & $\begin{array}{l}4.9 \\
--\end{array}$ & $\begin{array}{l}40 \\
--\end{array}$ & $\begin{array}{l}57 \\
43\end{array}$ & $\begin{array}{c}<0.005^{2} \\
-\end{array}$ & $\begin{array}{l}<0.1 \\
<0.2\end{array}$ & $\begin{array}{l}17.8 \\
12.7\end{array}$ & $\begin{array}{l}85 \\
48\end{array}$ & $\begin{array}{r}122 \\
50\end{array}$ & $\begin{array}{l}0.5 \\
0.4\end{array}$ & $\overline{94}$ & $61\left(26^{\circ} \mathrm{C}\right)$ \\
\hline BY-106 & $\begin{array}{l}05 / 04 / 94(2) \\
07 / 08 / 94(3)\end{array}$ & $\begin{array}{r}<1 \\
--\end{array}$ & $\begin{array}{l}5.7 \\
--\end{array}$ & $\begin{array}{l}60 \\
--\end{array}$ & $\begin{array}{l}87 \\
74\end{array}$ & $<0.01--$ & $\begin{array}{l}<0.2 \\
<0.2\end{array}$ & $\begin{array}{l}6.3 \\
9.9\end{array}$ & $\begin{array}{l}46 \\
46\end{array}$ & $\begin{array}{l}94 \\
71\end{array}$ & $\overline{0.5}$ & $\overline{47.6}$ & $57\left(27^{\circ} \mathrm{C}\right)$ \\
\hline BY-107 & $\begin{array}{l}03 / 25 / 94(2) \\
10 / 26 / 94(3)\end{array}$ & $\begin{array}{c}3-4 \\
--\end{array}$ & $\begin{array}{l}67 \\
-\end{array}$ & $\begin{array}{l}97 \\
--\end{array}$ & $\overline{972}$ & $\ddot{--}$ & $<\overline{0.2}$ & $\begin{array}{l}173 \\
150\end{array}$ & $\begin{array}{l}692 \\
267\end{array}$ & $\begin{array}{l}802 \\
621\end{array}$ & $\begin{array}{r}<5 \\
<20\end{array}$ & $\overline{94}$ & $36\left(33.1^{\circ} \mathrm{C}\right)$ \\
\hline BY-108 & $\begin{array}{l}03 / 28 / 94(2) \\
10 / 27 / 94(3)\end{array}$ & $\begin{array}{l}1 \\
--\end{array}$ & $\begin{array}{c}97 \\
--\end{array}$ & $\begin{array}{r}700 \\
--\end{array}$ & 1040 & -- & $\begin{array}{l}<0.5 \\
<0.1\end{array}$ & $\begin{array}{l}594 \\
510\end{array}$ & $\begin{array}{l}644 \\
400\end{array}$ & $\begin{array}{l}757 \\
641\end{array}$ & $\begin{array}{r}<5 \\
<76\end{array}$ & 224 & $56\left(25.7^{\circ} \mathrm{C}\right)$ \\
\hline BY-110 & $\begin{array}{l}09 / 27 / 92(1) \\
11 / 11 / 94(3) \\
\end{array}$ & $\begin{array}{r}<1 \\
-\end{array}$ & $\begin{array}{r}350 \\
-- \\
\end{array}$ & $\begin{array}{r}612 \\
-. \\
\end{array}$ & $40 \overline{1}$ & $\begin{array}{l}<2 \\
--\end{array}$ & $\begin{array}{l}<0.5 \\
<0.2\end{array}$ & $\overline{29}$ & $<160$ & 103 & $<\overline{<6}$ & 229 & $31\left(27^{\circ} \mathrm{C}\right)$ \\
\hline BY-111 & $\begin{array}{l}05 / 11 / 94(2) \\
11 / 16 / 94(3)\end{array}$ & $\begin{array}{r}<1 \\
--\end{array}$ & $\begin{array}{l}8.9 \\
--\end{array}$ & $\begin{array}{l}60 \\
--\end{array}$ & $\overline{59}$ & $\overline{-}$ & $<\overline{0.2}$ & $\overline{9} \overline{9.6}$ & -- & 99 & $\begin{array}{l}<1 \\
<1\end{array}$ & $2 \overline{19}$ & $27\left(27^{--} \mathrm{C}\right)$ \\
\hline BY-112 & $\begin{array}{l}03 / 26 / 93(1) \\
11 / 18 / 94(3)\end{array}$ & $\begin{array}{r}<1 \\
-- \\
\end{array}$ & $\begin{array}{l}5.9 \\
-- \\
\end{array}$ & $\begin{array}{l}10 \\
-.\end{array}$ & $\overline{63}$ & $\begin{array}{l}<2 \\
- \\
\end{array}$ & $\begin{array}{l}<0.5 \\
<0.2 \\
\end{array}$ & $\overline{5.8}$ & $<-\overline{-}$ & $\overline{40}$ & $<\overline{12}$ & $\overline{121}$ & $53\left(23.3^{\circ} \mathrm{C}\right)$ \\
\hline C-108 & $\begin{array}{l}07 / 23 / 93(* *) \\
07 / 07 / 94(2) \\
08 / 05 / 94(3) \\
\end{array}$ & $\begin{array}{l}1 \\
- \\
-- \\
\end{array}$ & $\begin{array}{l}1.2 \\
- \\
- \\
\end{array}$ & $\begin{array}{l}<2 \\
- \\
- \\
\end{array}$ & $\begin{array}{l}-- \\
2.7 \\
\end{array}$ & $\begin{array}{c}<2 \\
<0.0002^{i} \\
-\end{array}$ & $\begin{array}{l}<0.5 \\
<\overline{<0} \\
\end{array}$ & $\begin{array}{l}\quad- \\
<0.4 \\
<1.4 \\
\end{array}$ & $\overline{1--}$ & 344 & $\begin{array}{l}1 \\
\overline{0} .1\end{array}$ & $\overline{-}$ & $\begin{array}{c}\overline{-} \\
\overline{-} \\
76\left(25^{\circ} \mathrm{C}\right)\end{array}$ \\
\hline C-109 & $\begin{array}{l}06 / 23 / 94(2) \\
08 / 09 / 94(3) \\
\end{array}$ & $\begin{array}{r}<1 \\
-. \\
\end{array}$ & $\begin{array}{l}T \\
-\end{array}$ & $\begin{array}{l}4 \\
-- \\
\end{array}$ & $\overline{10.1}$ & - & $<0.6$ & $\overline{0} .65$ & $12 \overline{-}$ & 369 & $\overline{0.4}$ & $\overline{3}$ & $79\left(27^{\circ} \mathrm{C}\right)$ \\
\hline C-111 & $\begin{array}{l}08 / 10 / 93(* *) \\
06 / 20 / 94(2) \\
09 / 13 / 94(3)\end{array}$ & $\begin{array}{r}<1 \\
<1 \\
- \\
\end{array}$ & $\begin{array}{c}<0.2 \\
<0.2 \\
-- \\
\end{array}$ & $\begin{array}{l}<2 \\
<2 \\
- \\
\end{array}$ & $\begin{array}{l}\overline{0.1} \\
5.6\end{array}$ & $\begin{array}{c}<0.04^{2} \\
<0.01^{1} \\
- \\
\end{array}$ & $\begin{array}{l}<0.5 \\
<0.2 \\
\leq 0.7 \\
\end{array}$ & $\begin{array}{c}<0.3 \\
0.18 \\
<0.6 \\
\end{array}$ & $\begin{array}{l}16 \\
\overline{12.4}\end{array}$ & $\begin{array}{l}39 \\
- \\
99\end{array}$ & $\begin{array}{l}\overline{0.1} \\
\overline{0.1}\end{array}$ & $\overline{-}$ & $\begin{array}{c}\overline{-} \\
\overline{-}\left(27^{\circ} \mathrm{C}\right)\end{array}$ \\
\hline C-112 & $\begin{array}{l}06 / 24 / 94(2) \\
08 / 11 / 94(3) \\
\end{array}$ & $\begin{array}{l}<1 \\
-- \\
\end{array}$ & $\begin{array}{c}<0.2 \\
- \\
\end{array}$ & $\begin{array}{l}4 \\
- \\
\end{array}$ & $\overline{22.7}$ & $\overline{-}$ & $<\overline{0.7}$ & $\overline{3.4}$ & 204 & $5 \overline{544}$ & $\overline{0.9}$ & $1 \overline{102}$ & $82\left(28^{\circ} \mathrm{C}\right)$ \\
\hline T-107 & $\begin{array}{l}10 / 22 / 92(1) \\
01 / 18 / 95(3)\end{array}$ & $\begin{array}{r}<1 \\
-- \\
\end{array}$ & $\begin{array}{c}24 \\
\ldots\end{array}$ & $\begin{array}{r}203 \\
-- \\
\end{array}$ & $\overline{125}$ & $\begin{array}{l}<2 \\
-\end{array}$ & $\begin{array}{l}<0.5 \\
<0.1 \\
\end{array}$ & $\overline{1.4}$ & $<\overline{94}$ & $\overline{42}$ & $<\overline{12}$ & $\overline{75}$ & $82\left(17.2^{\circ} \mathrm{C}\right)$ \\
\hline
\end{tabular}


Table A-2. Ferrocyanide Tank Vapor Sampling Summary. (2 Sheets)

\begin{tabular}{|c|c|c|c|c|c|c|c|c|c|c|c|c|c|}
\hline Tank & $\begin{array}{c}\text { Date } \\
\text { Sampled } \\
\text { (Type) }\end{array}$ & $\begin{array}{c}\text { Flamm. } \\
(\% \text { LEL) }\end{array}$ & $\begin{array}{l}\text { Organic } \\
\text { Vapor } \\
(\text { ppmv) }\end{array}$ & $\begin{array}{c}\mathrm{NH}_{3} \\
(\text { ppmv })^{d}\end{array}$ & $\begin{array}{c}\mathrm{NH}_{3} \\
(\text { ppmv) }\end{array}$ & $\begin{array}{c}\mathrm{HCN} \\
(\operatorname{ppmv})^{d}\end{array}$ & $\begin{array}{l}\mathrm{NO}+\mathrm{NO}_{2} \\
(p p m v)^{d},\end{array}$ & $\begin{array}{l}\text { TNMOC } \\
\left(\mathrm{mg} / \mathrm{m}^{3}\right)^{f}\end{array}$ & $\begin{array}{c}\mathrm{H}_{2} \\
(\text { ppmv) }\end{array}$ & $\begin{array}{c}\mathrm{N}_{2} \mathrm{O} \\
(\text { ppmv) }\end{array}$ & $\begin{array}{c}\mathrm{CO} \\
(\mathrm{ppmv})^{\mathrm{s}}\end{array}$ & $\begin{array}{c}\mathrm{CO}_{2} \\
(p p m v)^{8}\end{array}$ & $\begin{array}{c}\text { Water } \\
\text { Content } \\
\text { \% RH }\left({ }^{\circ} \mathrm{C}\right)^{\mathrm{k}}\end{array}$ \\
\hline TX-118 & $\begin{array}{c}07 / 28 / 93(* *) \\
09 / 07 / 94(2) \\
12 / 16 / 94(3)\end{array}$ & $\begin{array}{r}<1 \\
<1 \\
-\end{array}$ & $\begin{array}{l}0.3 \\
7.8 \\
--\end{array}$ & $\begin{array}{l}10 \\
28 \\
--\end{array}$ & $\begin{array}{l}-- \\
-- \\
33\end{array}$ & $\begin{array}{c}<2 \\
<0.02 \\
-\end{array}$ & $\begin{array}{c}<0.5 \\
<0.5 \\
--\end{array}$ & $\begin{array}{l}-- \\
9.3 \\
--\end{array}$ & $\begin{array}{r}-\overline{97} \\
<94\end{array}$ & $\begin{array}{l}-- \\
17 \\
29\end{array}$ & $\begin{array}{r}-\overline{2.5} \\
<12\end{array}$ & $\begin{array}{l}-- \\
54 \\
98\end{array}$ & $\begin{array}{c}-- \\
-- \\
42\left(21.5^{\circ} \mathrm{C}\right)\end{array}$ \\
\hline TY-101 & $\begin{array}{l}08 / 04 / 94(2) \\
04 / 06 / 95(3)\end{array}$ & $\begin{array}{r}<1 \\
-\end{array}$ & $\begin{array}{l}4 \\
--\end{array}$ & $\begin{array}{l}12 \\
--\end{array}$ & $\begin{array}{l}16 \\
16\end{array}$ & $\begin{array}{c}<0.01 \\
.-\end{array}$ & $\begin{array}{l}<0.2 \\
<0.2\end{array}$ & $\overline{--}$ & $<\overline{--}$ & $\overline{98}$ & $<\overline{12}$ & $\overline{83}$ & $77\left(15.6^{\circ} \mathrm{C}\right)$ \\
\hline TY-103 & $\begin{array}{l}08 / 04 / 94(2) \\
04 / 11 / 95(3)\end{array}$ & $\begin{array}{c}<1 \\
-\end{array}$ & $\begin{array}{l}5 \\
-\end{array}$ & 30 & $\begin{array}{l}31 \\
49\end{array}$ & $\begin{array}{c}<0.01 \\
\ldots-\end{array}$ & $\begin{array}{l}<0.1 \\
<0.2\end{array}$ & -- & $<93$ & 159 & $<\overline{12}$ & $1 \overline{21}$ & $85\left(15.9^{\circ} \mathrm{C}\right)$ \\
\hline TY-104 & $\begin{array}{l}08 / 05 / 94(2) \\
04 / 27 / 95(3)\end{array}$ & $\begin{array}{r}<1 \\
--\end{array}$ & $\begin{array}{l}2.5 \\
-\end{array}$ & $\begin{array}{l}24 \\
--\end{array}$ & $\begin{array}{l}50 \\
61\end{array}$ & - & $\begin{array}{l}<0.2 \\
50.2\end{array}$ & $\overline{3}$ & $<49$ & 98 & $<23$ & $<\overline{-}$ & $88\left(15.6^{\circ} \mathrm{C}\right)$ \\
\hline
\end{tabular}

Sample Type:

** Vapor samples taken from in-tank, non-heated tubes using a vapor sampling cart (SUMMA ${ }^{\mathrm{TM}}$ only - no $\mathrm{NH}_{3}$ ).

1 Monitoring performed by Industrial Hygiene technicians using three varying length, non-heated sampling tubes into the tank dome space to evaluate for flammability and toxic vapors; this method is no longer used.

2 In Situ Sampling (ISS) - Sampling is performed by lowering special sorbent traps into the tank dome space that are connected topside to a portable handcart.

3 Sampling involves the mobile vapor sampling system (VSS), heated transfer lines, and installation of a water-heated sampling probe into the tank dome space. All ferrocyanide are scheduled for resampling using this method.

- Measuréd using a combustible gas meter; LEL = Lower Explosive Limit.

- Measured using a Organic Vapor Monitor (OVM). OVM readings are affected by ammonia; OVM ammonia

response is about $13: 1$, so that 13 ppmv of ammonia is indicated as 1 ppmv of organic vapors (ppmv = parts per million by volume).

d For Type 1 sampling only; value is measured using colorimetric (Dräger ${ }^{\mathrm{TM}}$ ) tubes (values are estimated, and not quantitative).

- Analyses of ammonia sorbent trap samples.

i Total non-methane organic compound (TNMOC) concentrations measured for SUMMA ${ }^{\mathrm{TM}}$ canister samples.

- Analyses of SUMMA ${ }^{\mathrm{TM}}$ canister samples from Type **, and 3 sampling methods

h \% RH is the percent relative humidity calculated from measured dome space water content (mg/L), temperature and atmospheric pressure. Temperature of dome space gas in ${ }^{\circ} \mathrm{C}$ is listed in parentheses.

i HCN determinations obtained in selected tanks using a special sorbent trap; values shown are below detection limit of the measurement technique.

j - Data not yet available or not obtained by this type of sampling.

This HCN number was $<0.04$ parts per billion vapor as determined by a special sodium hydroxide bubbler. 


\section{DISTRIBUTION}

Number of copies

\section{OFFSITE}

U.S. Department of Energy

EM-36, Trevion II

12800 Middlebrook Road

Germantown, MD 20874

James V. Antizzo, EM-36

Charles O'Dell, EM-36 (5)

U.S. Department of Energy

Forrestal Building

1000 Independence Avenue SW

Washington, DC 20585

Shirley Campbell, EH-71

1

U.S. Department of Energy

656 Quince Diamond Road

Room 235, EM-20.1

Gaithersburg, MD 20879

Cynthia Hilland

1

U.S. Department of Energy

Savannah River Operations Office

P.O. Box A

Aiken, SC 29808

Thomas C. Temple

1

Charles S. Abrams

1987 Virginia

Idaho Falls, ID 83404

1 David O. Campbell

102 Windham Road

Oak Ridge, TN 37830 


\section{DISTRIBUTION (Continued)}

Number of copies

\section{OFFSITE}

Fred N. Carlson

6965 North 5th West

Idaho Falls, ID 83401

1

Billy C. Hudson

202 Northridge Court

Lindsborg, KA 67456

1

William R. Prindle

1556 Crestline Drive

Santa Barbara, CA 93105

1

Alfred Schneider

5005 Hidden Branches Drive

Dunwoody, GA 30338

1

Air Products \& Chemicals, Inc.

7201 Hamilton Blvd

Allentown, PA 18195-1501

George E. Schmauch

1

Brookhaven National Laboratory

Upton, NY 11973

Kamal K. Bandyopadhyay

1

Design Science, Inc.

163 Witherow Road

Sewickley, PA 15143

Gary Powers

2

Fauske and Associates, Inc.

16W070 W. 83rd St.

Burr Ridge, IL 60521

Michael Epstein

Hans K. Fauske 


\section{DISTRIBUTION (Continued)}

Number of copies

\section{OFFSITE}

1

Florida State University

Department of Chemistry B-164

Tallahassee, FL 32306

Greg R: Choppin

2

G \& P Consulting, Inc.

3640 Ballard Road

Dallas, OR 97338

J. Michael Grigsby

Arlin K. Postma

1

Harvard University

295 Upland Avenue

Newton Highlands, MA 02161

Melvin W. First

1

Hazards Research Corporation

200 Valley Road, Suite 301

Mt. Arlington, NJ 07856

Chester Grelecki

3

Los Alamos National Laboratory

P.O. Box 1663

Los Alamos, NM 87545

Steve F. Agnew

Steve W. Eisenhawer

Thomas E. Larson

1

MIT/Department of Nuclear Engineering

77 Massachusetts Ave.

Room 24-102

Cambridge, MA 02139

Mujid S. Kazimi 


\section{DISTRIBUTION (Continued)}

Number of copies

\section{OFFSITE}

Nuclear Consulting Services. Inc.

P.O. Box 29151

Columbus, $\mathrm{OH}$ 43229-0151

J. Louis Kovach

Oak Ridge National Laboratory

1

Emory D. Collins

P.O. Box 2008

7930, MS-6385

Oak Ridge, TN 37831-6385

1

Charles W. Forsberg

P.O. Box 2008

MS-6495

Oak Ridge, TN 37831-6495

1

Thomas S. Kress

P.O. Box 2009

9108, MS-8088

Oak Ridge, TN 37831-8088

1

Rice University

5211 Paisley

Houston, TX 77096

Andrew S. Veletsos

2

Sandia National Laboratories

P.O. Box 5800

Albuquerque, NM 87185

Dana A. Powers, MS-0744

Scott E. Slezak, MS-0741 


\section{DISTRIBUTION (Continued)}

Number of copies

\section{OFFSITE}

Science Applications International Corporation 20300 Century Blvd, Suite 200-B

Germantown, MD 20874

Ray S. Daniels (3)

State of Washington - Department of Ecology

1

Michael T. Gordon

P. O. Box 47600

Olympia, WA $98504-7600$

1

Alex Stone

1315 W. 4th Avenue

Kennewick, WA 99336

1

University of South Carolina

Department of Electrical and Computer Engineering

Swearingen Engineering Center

Columbia, SC 29208

Joseph S. Byrd

1

University of Washington

Center for Process Analytical Chemistry

Chemistry Department BG-10

Seattle, WA 98195

Bruce R. Kowalski

1

Vanderbilt University

P.O. Box 1596, Station B

Nashville, TN 37235

Frank L. Parker 
DISTRIBUTION (Continued)

Number of copies

OFFSITE

1

Waste Policy Institute

555 Quince Orchard Road, Suite 600

Gaitherburg, MD 20878-1437.

Donald T. Oakley

\section{ONSITE}

10

U.S. Department of Energy,

Richland Operations Office

R. E. Gerton (2)

S7-54

R. G. Harwood

S7-54

W. F. Hendrickson

S7-54

D. H. Irby (2)

S7-54

A. G. Krasopoulos

A4-81

Public Reading Room

H2-53

RL Docket File (2)

H5-36

Pacific Northwest Laboratory

S. A. Bryan

P7-25

R. T. Hallen

P8-38

M. A. Lilga

P8-38

R. D. Scheele

P7-25

C. S. Simmons

K6-77

C. W. Stewart

K7-15

Hanford Technical Library

P8-55

Westinghouse Hanford Company

H. Babad

S7-30

J. B. Billetdeaux

S7-16

D. C. Board

S1-57

W. S. Callaway

$\mathrm{X} 2-10$

R. J. Cash (5)

S7-15

M. D. Crippen

L5-31 


\section{DISTRIBUTION (Continued)}

R. D. Crowe

H0-38

D. R. Dickinson

L5-31

G. T. Dukelow

S7-15

M. N. Islam

R3-08

D. W. Jeppson

L5-31

N. W. Kirch

R2-11

C. A. Kuhlman

B3-30

E. J. Lipke

S7-14

L. L. Lockrem

S3-90

J. M. McLaren

H0-34

J. E. Meacham (2)

S7-15

N. J. Milliken

H4-62

S. R. Moreno

B3-06

T. V. Rebagay

T6-30

F. R. Reich

L5-63

E. F. Riedel

S3-90

B. C. Simpson

R2-12

H. Toffer

H0-38

W. T. Watson

H0-38

W. D. Winkelman

L5-55

W. D. Wittekind

H0-38

Central Files

A3-88

EDMC

H6-08

OSTI (2)

A3-36

TFIC

R1-20 